ORNL/ER-203/R1

LOCKHEED MATTI

ENVIRONMENTAL

RESTORATION

PROGRAM

-

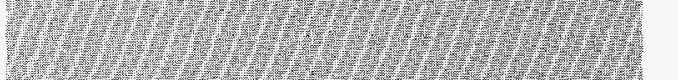

3.
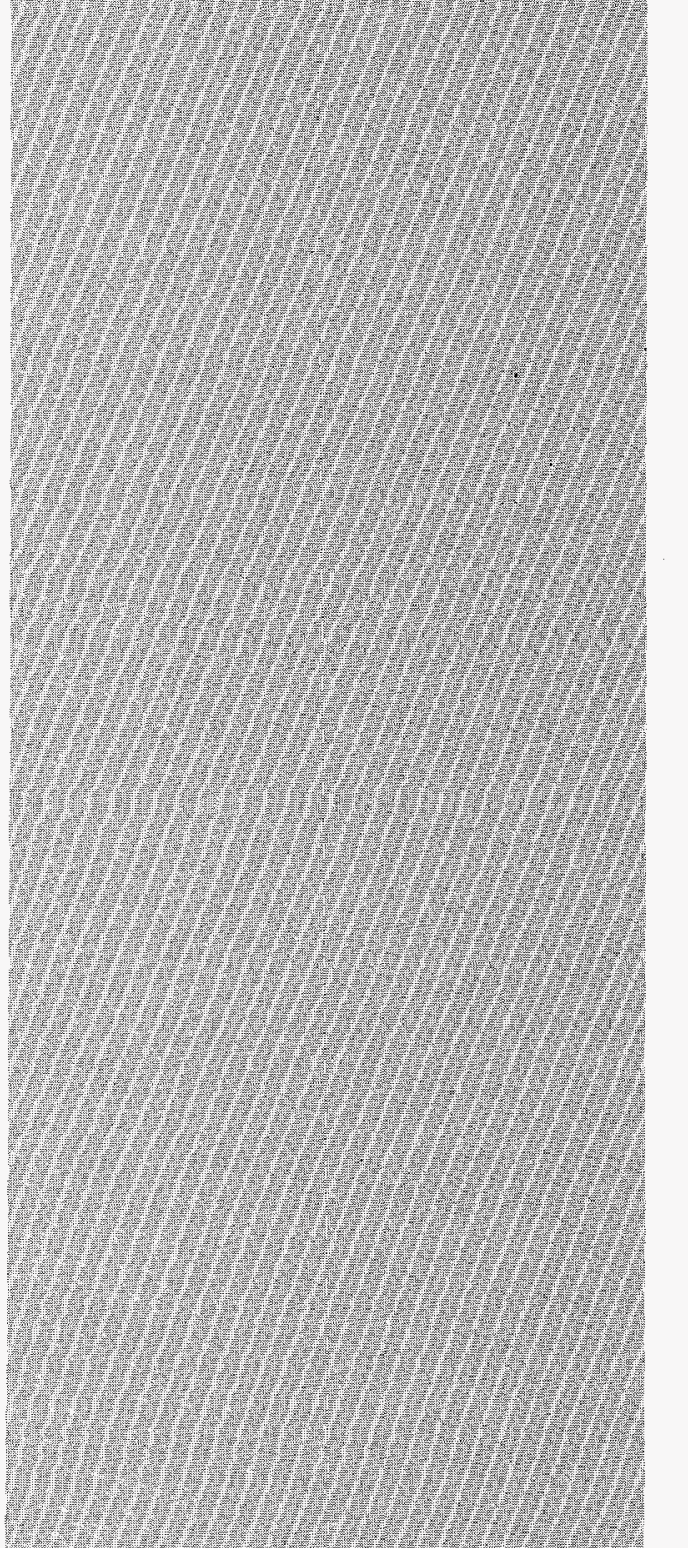

\section{Groundwater Quality Sampling and Analysis Plan for Environmental Monitoring in Waste Area Grouping 6 at Oak Ridge National Laboratory}

RECEIVED

MAR $O 11936$

OSTI 


\section{CDM Federal Programs Corporation}

contributed to the preparation of this document and should not be considered an eligible contractor for its review.

This report has been reproduced directly from the best available copy.

Avallable to DOE and DOE contractors from the Office of Sclentific and Technical Information, P.O. BOx 62, Oak Ridge, TN 37831; prices available from 615-576-8401.

Available to the public from the National Technical Information Service, U.S. Department of Commerce, 5285 Pon Royal Rd, Springfield, VA 22161.

\section{DESCLAMER}

This report was prepared as an account of work sponsored by an agency of the United States Government. Neither the United States Government nor any agency thereof, nor any of their employees, makes any warranty, express or implied, or assumes any legal liability or responsibility for the accuracy, completeness, or usefulness of any information, apparatus, product, or process disclosed, or represents that its use would not infringe privately owned rights. Reference berein to any specific commercial product, process, or service by trade name, trademark, manufacturer, or otherwise, does not necessarity constitute or imply its endorsement, recommendation, or favoring by the United States Government or any agency thereof. The views and opinions of authors expressed herein do not necessarily state or reffect those of the United States Government or any agency thereof. 
Energy Systems Environmental Restoration Program ORNL Environmental Restoration Program

Groundwater Quality Sampling and Analysis Plan for Environmental Monitoring in Waste Area Grouping 6 at Oak Ridge National Laboratory

Date Issued-September 1995

Prepared by

CDM Federal Programs Corporation

Oak Ridge, Tennessee 37830

Prepared for

U.S. Department of Energy

Office of Environmental Management under budget and reporting code EW 20

Environmental Restoration and Waste Management Programs

OAK RIDGE NATIONAL LABORATORY

Oak Ridge, Tennessee 37831-8169

managed by

LOCKHEED MARTIN ENERGY SYSTEMS, INC.

for the

U.S. DEPARTMENT OF ENERGY

under contract DE-AC05-84OR21400 
Groundwater Quality Sampling and Analysis Plan for the Environmental Monitoring Plan in Waste Area Grouping 6 at Oak Ridge National Laboratory, Oak Ridge, Tennessee Revision 1

Approvals

D. L. Garrett WAG 6 Project Manager

P. A. Schrandt Environmental Restoration Quality Assurance Specialist
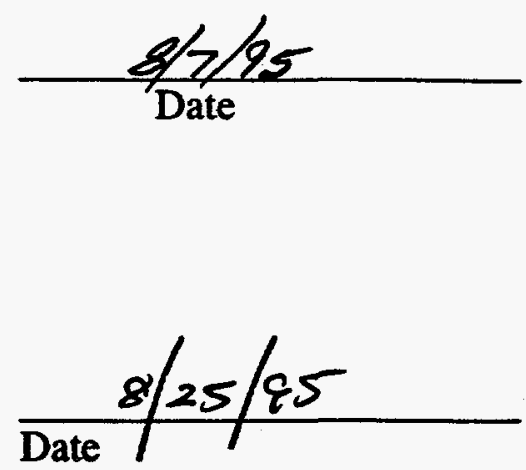


\section{PREFACE}

This Groundwater Quality Sampling and Analysis Plan for Environmental Monitoring in Waste Area Grouping 6 at Oak Ridge National Laboratory (ORNL/ER-203/R1) was prepared in accordance with requirements under the Comprehensive Environmental Response, Compensation, and Liability Act (CERCLA). This work was performed under Work Breakdown Structure 1.4.12.06.01.01 (Activity Data Sheet 3306 "WAG 6"). This document reflects general changes since it was originally issued and incorporates changes derived from the Change Control Log. 


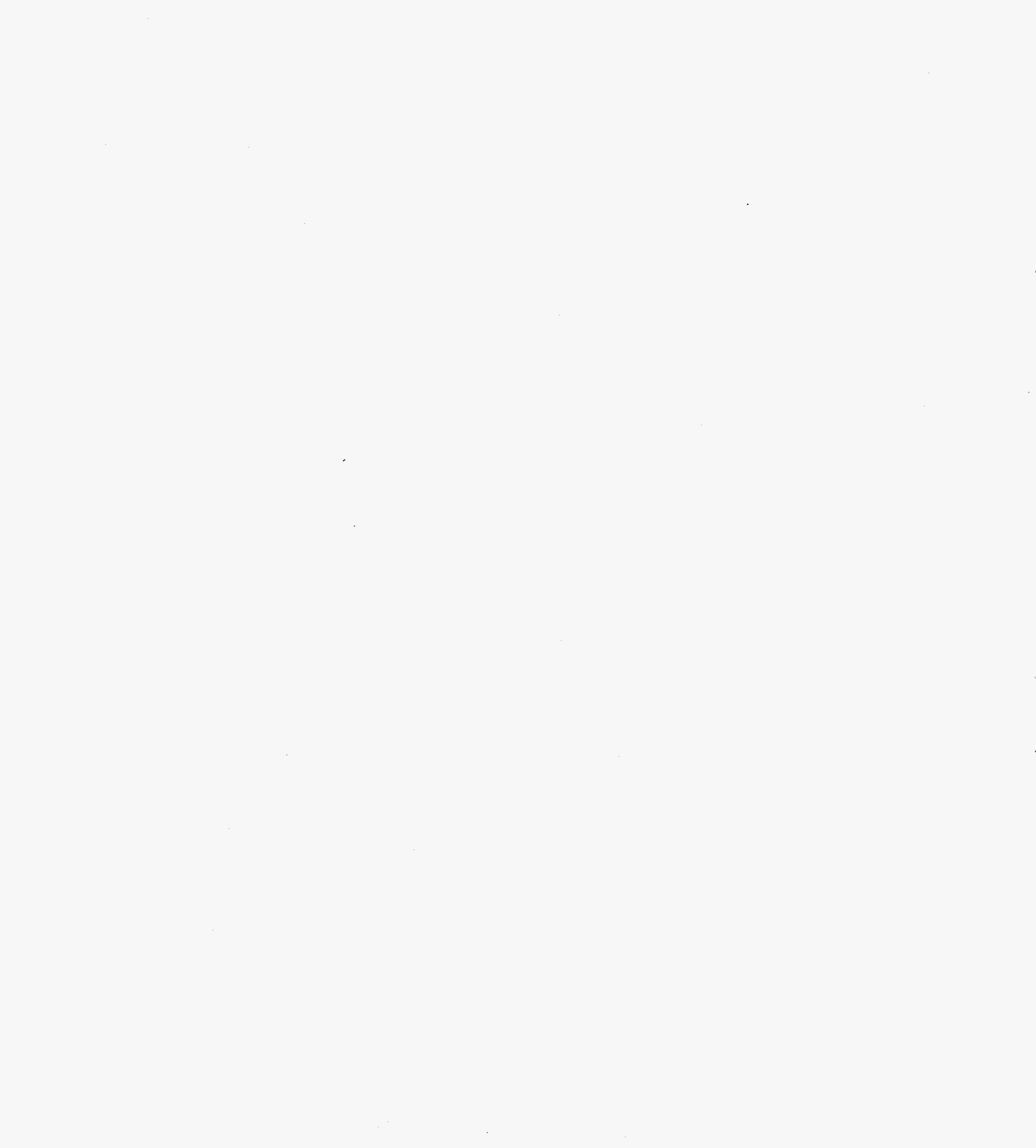




\section{CONTENTS}

FIGURES $\ldots \ldots \ldots \ldots \ldots \ldots \ldots \ldots \ldots \ldots \ldots \ldots \ldots \ldots \ldots \ldots$

TABLES $\ldots \ldots \ldots \ldots \ldots \ldots \ldots \ldots \ldots \ldots \ldots \ldots \ldots \ldots \ldots \ldots \ldots$

ABBREVIATIONS $\ldots \ldots \ldots \ldots \ldots \ldots \ldots \ldots \ldots \ldots \ldots \ldots \ldots \ldots \ldots$

EXECUTIVE SUMMARY $\ldots \ldots \ldots \ldots \ldots \ldots \ldots \ldots \ldots \ldots \ldots \ldots \ldots$

1. INTRODUCTION $\ldots \ldots \ldots \ldots \ldots \ldots \ldots \ldots \ldots \ldots \ldots \ldots \ldots \ldots \ldots$

1.1 PROJECT OVERVIEW $\ldots \ldots \ldots \ldots \ldots \ldots \ldots \ldots \ldots \ldots \ldots \ldots$. 1

1.2 GROUNDWATER QUALITY SAP OUTLINE AND OBJECTIVES $\ldots \ldots \ldots$ 1-1

1.3 SAMPLING LOCATIONS, FREQUENCIES, AND ANALYTES $\ldots \ldots \ldots$. . . 1-3

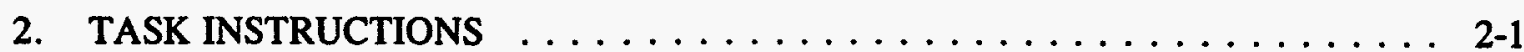

2.1 GROUNDWATER LEVEL MEASUREMENTS $\ldots \ldots \ldots \ldots \ldots \ldots \ldots$. . . . .

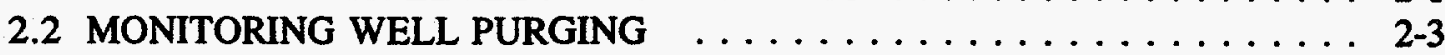

2.3 GROUNDWATER SAMPLING $\ldots \ldots \ldots \ldots \ldots \ldots \ldots \ldots \ldots$

3. QUALITY ASSURANCE/QUALITY CONTROL REQUIREMENTS $\ldots \ldots \ldots$. . 3-1

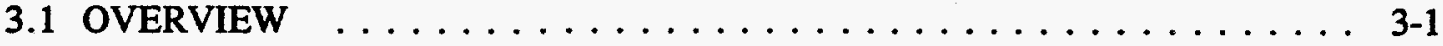

3.2 MONITORING PROGRAM ORGANIZATION $\ldots \ldots \ldots \ldots \ldots \ldots \ldots$ 3-1

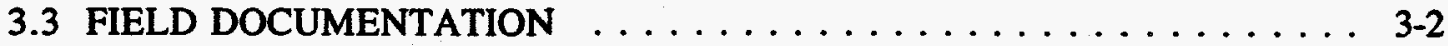

3.4 SAMPLE IDENTIFICATION AND LABELING $\ldots \ldots \ldots \ldots \ldots \ldots \ldots$. . $\ldots \ldots$

3.5 CHAIN OF CUSTODY . . . . . . . . . . . . . . . . . . 3-7

3.6 ACTIVITY-SPECIFIC QUALITY ASSURANCE/QUALITY CONTROL REQUIREMENTS $\ldots \ldots \ldots \ldots \ldots \ldots \ldots \ldots \ldots$. . . . . . . . .

4. HEALTH AND SAFETY CONSIDERATIONS $\ldots \ldots \ldots \ldots \ldots \ldots \ldots \ldots$

5. WASTE MANAGEMENT $\ldots \ldots \ldots \ldots \ldots \ldots \ldots \ldots \ldots \ldots \ldots$

5.1 ORGANIZATIONAL RESPONSIBILITIES $\ldots \ldots \ldots \ldots \ldots \ldots \ldots$ 5-1

5.2 GUIDANCE DOCUMENTS . . . . . . . . . . . . . . . $5-2$

5.3 WASTE CHARACTERIZATION/SEGREGATION $\ldots \ldots \ldots \ldots \ldots \ldots$. $\ldots \ldots$

5.3.1 Solid Waste . . . . . . . . . . . . . . . . . 5-4

5.3 .2 Liquid Waste $\ldots \ldots \ldots \ldots \ldots \ldots \ldots \ldots \ldots$. . . . . . . . . .

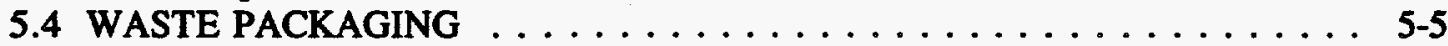

5.5 WASTE TRANSPORTATION $\ldots \ldots \ldots \ldots \ldots \ldots \ldots \ldots$

6. DATA MANAGEMENT $\ldots \ldots \ldots \ldots \ldots \ldots \ldots \ldots \ldots \ldots \ldots$ 6

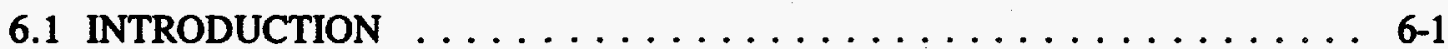

6.2 DATA DOWNLOADING $\ldots \ldots \ldots \ldots \ldots \ldots \ldots \ldots \ldots \ldots \ldots \ldots$

6.3 PROCEDURES FOR COMPLETING GROUNDWATER QUALITY (GWQ) FORMS ..................... 6-1

6.4 PROCEDURES FOR COMPLETING SAMPLE COLLECTION FORMS . . . . 6-2 


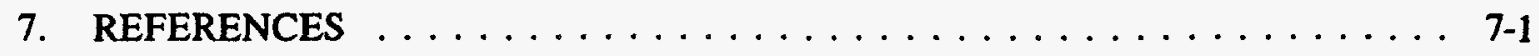

APPENDIX A: FIELD FORMS $\ldots \ldots \ldots \ldots \ldots \ldots \ldots \ldots \ldots \ldots \ldots$

APPENDIX B: SAMPLING SCHEDULES $\ldots \ldots \ldots \ldots \ldots \ldots \ldots \ldots$ B-1

APPENDIX C: SITE-SPECIFIC HAZARD EVALUATION ADDENDUM

FOR WAG 6 GROUNDWATER QUALITY . . . . . . . . . C 1 


\section{FIGURES}

1.1. Locations of groundwater quality monitoring wells $\ldots \ldots \ldots \ldots \ldots$. . . . . .

2.1. Groundwater quality sampling and analysis activity task flowchart $\ldots \ldots \ldots$. . . 2

3.1. CDM Federal WAG 6 Environmental Monitoring Plan implementation

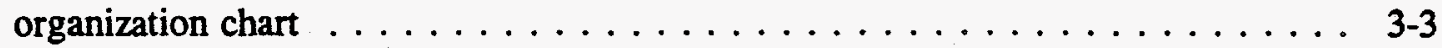




\section{TABLES}

1.1. WAG 6 Groundwater Quality SAP and project-level document cross-reference . . 1-2

1.2. Groundwater Quality SAP activities, purposes, and quality control levels $\ldots \ldots$ 1-3

1.3. Analytical suites and associated analytes for groundwater quality sampling $\ldots \ldots$ 1-5

1.4. Groundwater quality sampling locations, analytical suites, and frequencies . . . . 1-6

2.1. Sample containers, preservatives, and holding times for groundwater samples from groundwater quality monitoring wells in WAG $6 \ldots \ldots \ldots \ldots$

3.1. General responsibilities of WAG 6 EMP principal contractor personnel . . . . . . . 3-4

3.2. Types of WAG 6 EMP field documentation and the information

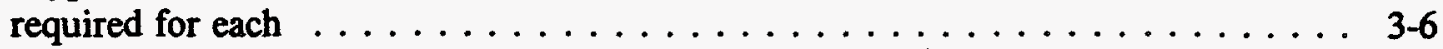

3.3. Quality control sample types and frequencies for groundwater quality

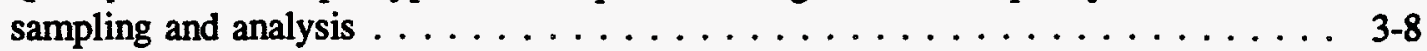

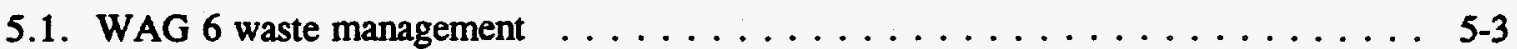





\begin{tabular}{|c|}
\hline \multirow{3}{*}{$\begin{array}{l}\text { ASME } \\
\text { CDM Federal } \\
\text { CFR }\end{array}$} \\
\hline \\
\hline \\
\hline CLP \\
\hline $\mathrm{COC}$ \\
\hline DCG \\
\hline DIC \\
\hline DOC \\
\hline DOE \\
\hline EMP \\
\hline Energy Systems \\
\hline EPA \\
\hline ESP \\
\hline FID \\
\hline FOP \\
\hline FTM \\
\hline GCO \\
\hline GPM \\
\hline GWQ \\
\hline H\&S \\
\hline HP \\
\hline ID \\
\hline IH \\
\hline LGWOD \\
\hline MS \\
\hline MSD \\
\hline ORNL \\
\hline OSHA \\
\hline PCB \\
\hline PID \\
\hline PPE \\
\hline QA \\
\hline$Q C$ \\
\hline RCRA \\
\hline RFI \\
\hline SAP \\
\hline SHSO \\
\hline SLLW \\
\hline STL \\
\hline SWSA \\
\hline WAG \\
\hline WMO \\
\hline WMP \\
\hline
\end{tabular}

American Society of Mechanical Engineers

CDM Federal Programs Corporation

Code of Federal Regulations

Contract Laboratory Program

chemical of concern

Derived Concentration Guide

dissolved inorganic carbon

dissolved organic carbon

Department of Energy

Environmental Monitoring Plan

Martin Marietta Energy Systems, Inc.

U.S. Environmental Protection Agency

environmental surveillance procedure

flame ionization detector

field operations procedure

Field Task Manager

Government Contracting Officer

gallons per minute

Groundwater Quality

health and safety

Health Physics Section

identification

Industrial Hygiene Section

Liquid and Gaseous Waste Operations Department

matrix spike

matrix spike duplicate

Oak Ridge National Laboratory

Occupational Safety and Health Administration

polychlorinated biphenyl

photoionization detector

personal protective equipment

quality assurance

quality control

Resource Conservation and Recovery Act

RCRA Facility Investigation

sampling and analysis plan

site health and safety officer

solid low-level waste

Sample Task Leader

solid waste storage area

waste area grouping

Waste Management Operations

waste management plan 



\section{EXECUTIVE SUMMARY}

This Sampling and Analysis Plan addresses groundwater quality sampling and analysis activities that will be conducted in support of the Environmental Monitoring Plan for Waste Area Grouping (WAG) 6 . WAG 6 is a shallow-burial land disposal facility for low-level radioactive waste at the Oak Ridge National Laboratory, a research facility owned by the U.S. Department of Energy and managed by Martin Marietta Energy Systems, Inc. (Energy Systems). Groundwater sampling will be conducted by Energy Systems at 45 wells within WAG 6 . The samples will be analyzed for various organic, inorganic, and radiological parameters. The information derived from the groundwater quality monitoring, sampling, and analysis will aid in evaluating relative risk associated with contaminants migrating off-WAG, and also will fulfill Resource Conservation and Recovery Act (RCRA) interim permit monitoring requirements. The sampling steps described in this plan are consistent with the steps that have previously been followed by Energy Systems when conducting RCRA sampling. 


\section{INTRODUCTION}

\subsection{PROJECT OVERVIEW}

This document is the Groundwater Quality Sampling and Analysis Plan (SAP) for Waste Area Grouping (WAG) 6 at Oak Ridge National Laboratory (ORNL). The procedures described herein are part of the Environmental Monitoring Plan (EMP) for WAG 6, which also includes monitoring tasks for groundwater levels, surface water, seeps and springs, and meteorological parameters. Separate SAPs are being issued concurrently to describe each of these monitoring programs.

This SAP has been written for the use of the field personnel responsible for implementation of the EMP, with the intent that the field personnel will be able to take this document to the field and quickly find the appropriate steps required to complete a specific task. In many cases, Field Operations Procedures (FOPs) will define the steps required for an activity. The FOPs for the EMP are referenced and briefly described in the relevant sections of the SAPs, and are contained within the FOP Manual. Both these documents (the SAP and the FOP Manual) will be available to personnel in the field.

Information regarding the WAG 6 physical description, geology and hydrogeology, and waste disposal and regulatory history can be found in the Resource Conservation and Recovery Act Facility Investigation Report for Waste Area Grouping 6 at Oak Ridge National Laboratory, Oak Ridge, Tennessee (Energy Systems 1991), and a description of the purpose and scope of the EMP can be found in the Environmental Monitoring Plan for Waste Area Grouping at Oak Ridge National Laboratory, Oak Ridge, Tennessee (DOE 1993a).

\subsection{GROUNDWATER QUALITY SAP OUTLINE AND OBJECTIVES}

The purpose of the groundwater quality SAP is to provide the field workers with information on conducting activities that are unique and essential to accomplishing the task of groundwater quality sampling. Some information that is important to field workers is contained in other project-level documents. To avoid duplication of this information [such as project-level quality assurance/quality control (QA/QC) and health and safety (H\&S) protocols], other documents have been referenced as appropriate. Table 1.1 displays the organization of this SAP and the relevant reference documents. All documents will be made available to the field workers before the initiation of field activities. Once field activities have begun, the field workers will carry the SAP and the FOP Manual to the field. The other reference documents will be available at the field office. Copies of these reference documents will be available to the field workers to carry into the field for direct reference as the need arises.

The objectives of the Groundwater Quality Monitoring Program, as defined in the EMP, are

- to verify primary chemicals of concern (COCs) that contribute to risk;

- to refine risk estimates; 
Table 1.1. WAG 6 Groundwater Quality SAP and project-level document cross-reference

Groundwater Quality SAP section

Section 1 - Introduction contains limited information on the EMP, summarizes project objectives, and summarizes the groundwater quality sampling activities to be conducted.

Section 2 - Task Instructions identifies the specific tasks to be conducted, contains activity-specific instructions on the work to be performed, and lists the procedures to be used at various stages of the work.

Section 3 - Quality Assurance/Quality Control Requirements contains information on the QA/QC requirements specific to groundwater quality monitoring. This section includes information on documentation; analytical requirements; and frequencies, numbers, and types of $Q C$ samples.

Section 4 - Health and Safety Considerations briefly describes the health and safety aspects of the activity. Activity-specific instruction sheets will be included in this section that will address specific health and safety issues that are not covered by the Site Health and Safety Plan.

Section 5 - Waste Management briefly describes the waste management associated with the groundwater quality monitoring. The wastes associated with this activity will be restricted to personal protective equipment, very small quantities of decontamination fluids, and purge water.

Section 6 - Data Management describes the data collection and management activities that will be conducted in the field, and the procedures for collecting these data to ensure that accurate data are transferred into the data base.
Project-level reference document(s)

DOE Environmental Monitoring Plan

DOE Environmental Monitoring Plan

WAG 6 Field Operations Procedures Manual

DOE Quality Assurance Project Plan for the Environmental Monitoring Program in Waste Arec Grouping 6 at Oak Ridge National Laboratory

Energy Systems Site Health and Safety Plan for Waste Area Grouping 6 at Oak Ridge National Laboratory

Energy Systems Waste Management Plan

Energy Systems Data Management Plan' Functional Systems Design

- to meet Resource Conservation and Recovery Act (RCRA) reporting requirements;

- to track and evaluate concentrations of site-related radionuclides detected above Derived Concentration Guide (DCG) levels, in compliance with U.S. Department of Energy (DOE) Orders 5400.5 and 5820.2A; and

- to identify major $\mathrm{COC}$ sources by tracking changes in groundwater beneath $\mathrm{COC}$ sources.

Field workers should keep these objectives in mind when conducting the activities described in this SAP. An understanding of, and a constant adherence to, the objectives of the EMP will ensure the collection of data in quantities and at the quality level necessary to meet the objectives. 
The activities identified in Table 1.2 will be conducted to meet these groundwater quality objectives.

Table 1.2. Groundwater Quality SAP activities, purposes, and quality control levels

\begin{tabular}{|c|c|c|}
\hline Groundwater Quality SAP activity & Activity purpose and elements & $\begin{array}{l}\text { EPA Quality } \\
\text { Control } \\
\text { Levels }^{\boldsymbol{c}}\end{array}$ \\
\hline 1. H\&S monitoring of site and uncapped well & $\begin{array}{l}\text { - Ensure worker health and } \\
\text { safety }\end{array}$ & Level I \\
\hline 2. Groundwater level measurements & - Data for groundwater model & Level I \\
\hline 3. Monitor well purging (indicator parameters) & $\begin{array}{l}\text { - Purge well for sample } \\
\text { collection }\end{array}$ & Level I \\
\hline 4. Groundwater sample collection and analysis & $\begin{array}{l}\text { - Risk calculations } \\
\text { - Confirmation of chemicals of } \\
\text { concern } \\
\text { - Groundwater geochemistry } \\
\text { characterization }\end{array}$ & $\begin{array}{l}\text { Level III } \\
(90 \%) \\
\text { Level IV } \\
(10 \%)\end{array}$ \\
\hline 5. Equipment decontamination & $\begin{array}{l}\text { - Eliminate cross-contamination } \\
\text { between wells }\end{array}$ & N/A $A^{*}$ \\
\hline 6. Waste management & $\begin{array}{l}\text { Properly document and } \\
\text { manage personal protective } \\
\text { equipment } \\
\text { and decontamination fluid }\end{array}$ & N/A \\
\hline 7. Data collection and management & $\begin{array}{l}\text { Properly record information in } \\
\text { logbooks and field forms; } \\
\text { properly download data from } \\
\text { electronic field instruments }\end{array}$ & N/A \\
\hline
\end{tabular}

${ }^{a}$ QC Levels I-IV in the EMP correspond to QC Levels A-D in the Quality Assurance Project Plan for this project (DOE 1993b).

WN/A = not applicable.

Groundwater samples will be collected by Energy Systems personnel as grab samples from selected monitoring wells. The samples will be obtained from the discharge of dedicated bladder pumps installed in each well. The discharge will be collected directly into the sample containers. Data from these activities will be collected by CDM Federal personnel on various forms (Appendix A) and in field logbooks. After the samples have been collected, CDM Federal personnel will package and ship the samples to a laboratory for analysis.

\subsection{SAMPLING LOCATIONS, FREQUENCIES, AND ANALYTES}

The EMP specifies that 42 groundwater monitoring wells will be sampled for various analytes and at various frequencies. The locations of all 42 wells are displayed in Fig. 1.1, together with other site features that are relevant to the specific activity of groundwater sampling. 



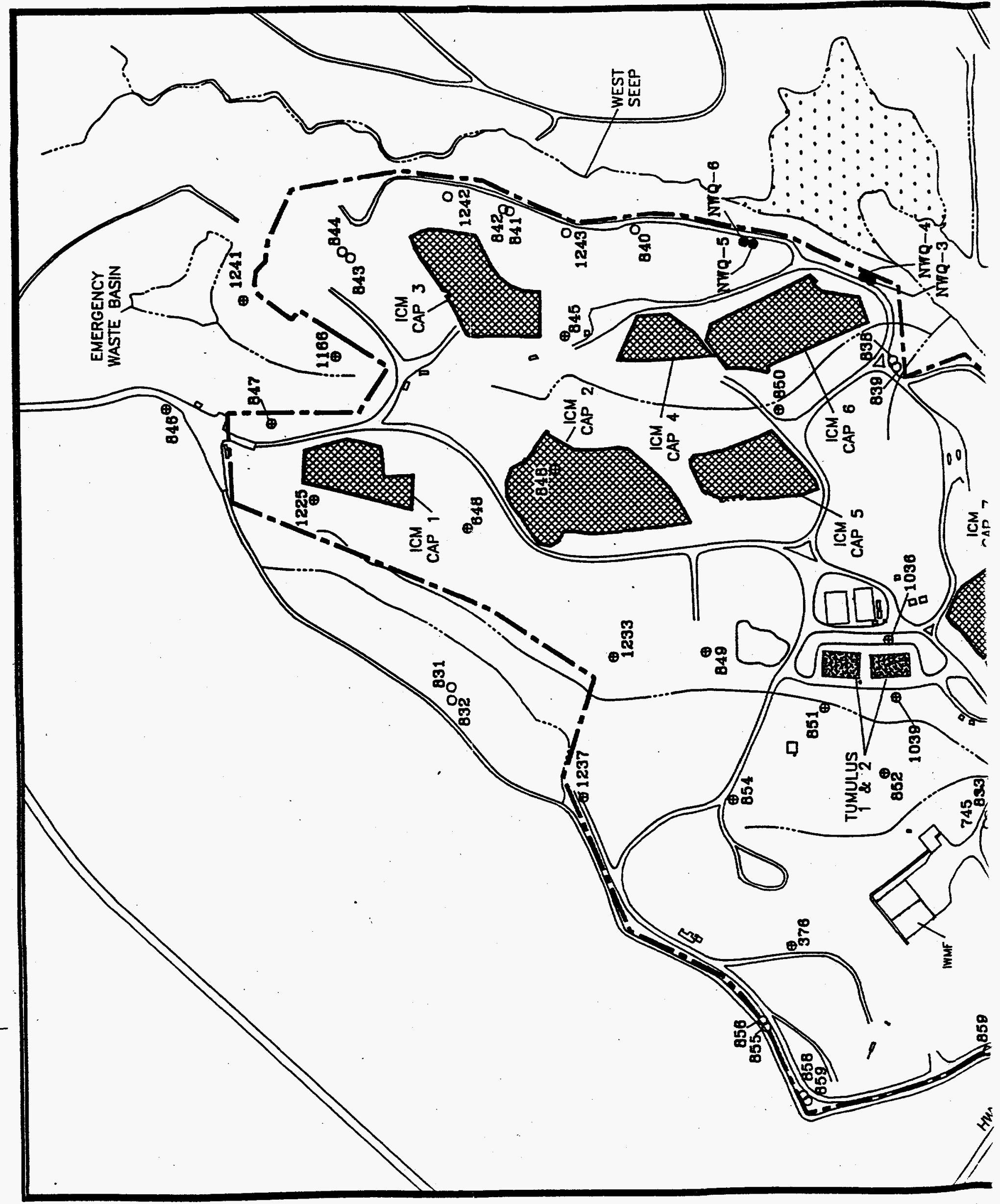


. 


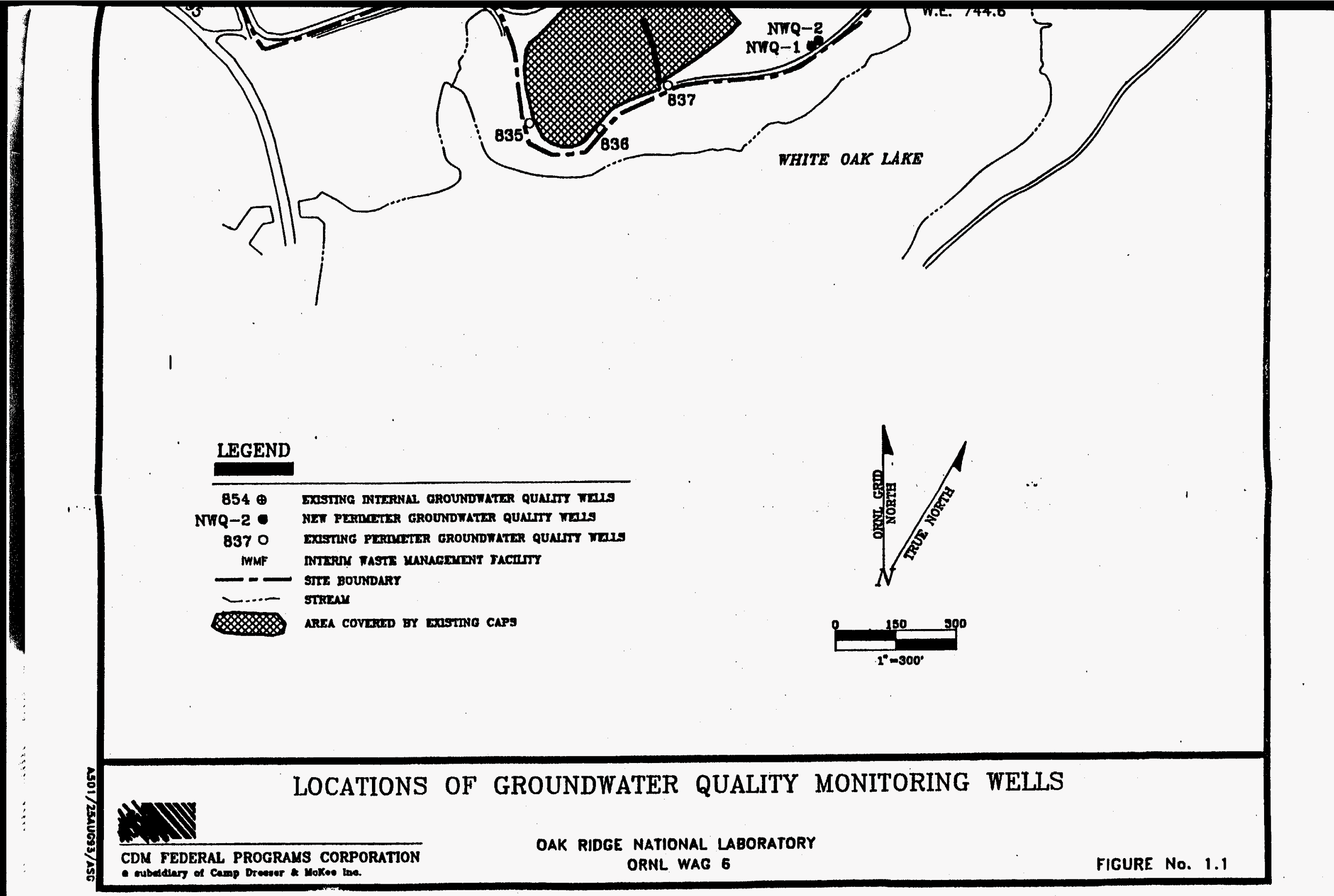



Table 1.3 displays the specific analyte list comprising the analytical suites. The frequency and analytical suite for each well are displayed in Table 1.4. Based upon the information contained in Tables 1.3 and 1.4, the sampling frequency and list of analytes for each well are displayed in Appendix B.

Table 1.3. Analytical suites and associated analytes for groundwater quality sampling

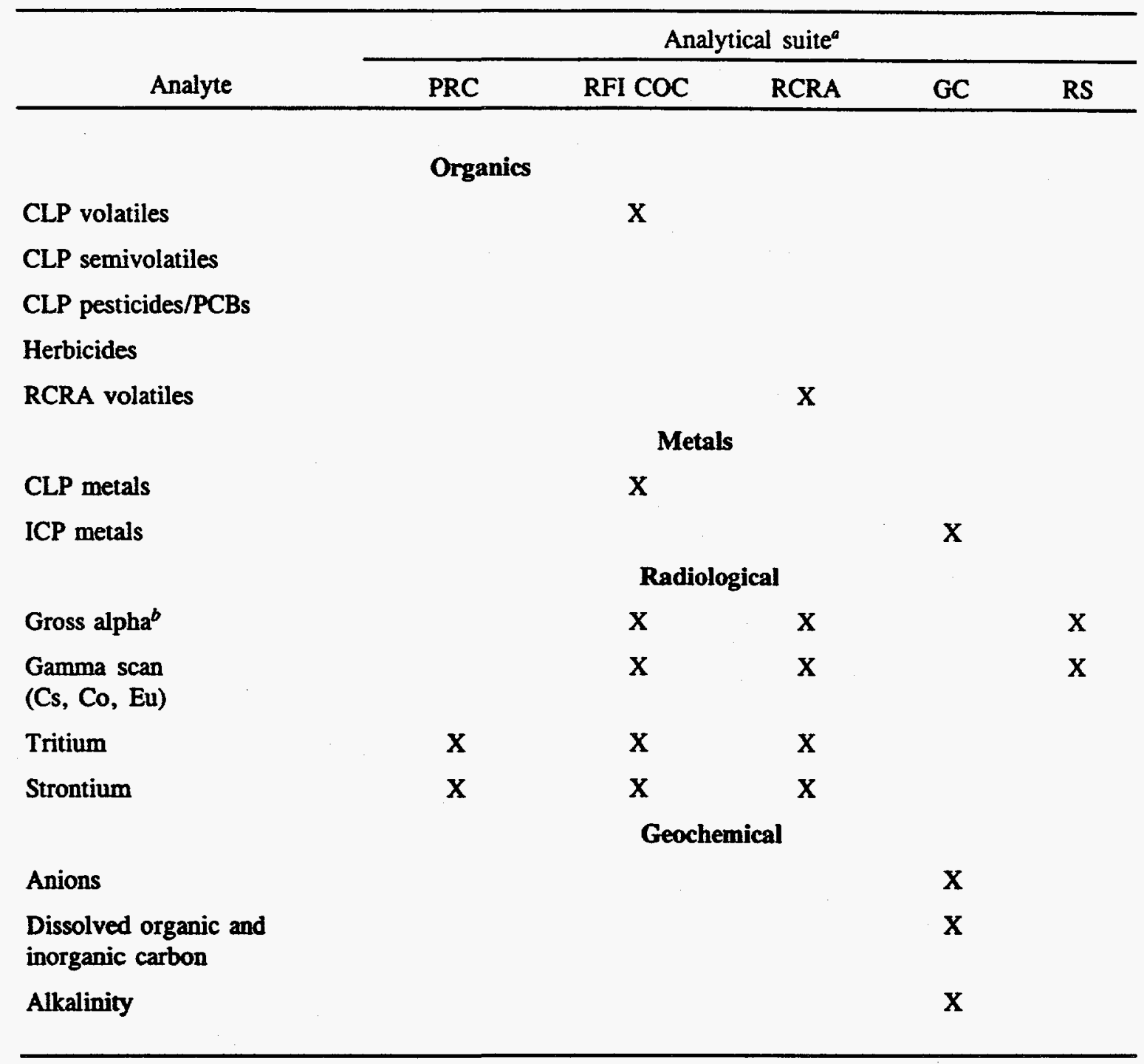

- PRC = Site-related chemicals that contribute to the majority of risk.

RFI COC = Site-related chemicals determined to be COCs during the Resource Conservation and Recovery Act (RCRA) Facility Investigation (RFI) sampling analysis.

RCRA = Volatile organic compounds (VOCs) and radionuclides required for reporting under RCRA and DOE Orders.

GC $=$ Geochemical parameters.

RS = Radiation scans.

${ }^{b}$ If the gross alpha level exceeds $5 \mathrm{pCi} /$, confirmation sampling will be required. If the confirmation also exceeds $5 \mathrm{pCi} / \mathrm{L}$ gross alpha, alpha spectroscopy will be conducted on an aliquot of the confirmation sample to determine the contributing radionuclide. 
Table 1.4. Groundwater quality sampling locations, analytical suites, and frequencies"

\begin{tabular}{|c|c|c|c|c|c|c|}
\hline & \multirow{2}{*}{\multicolumn{2}{|c|}{ Well Number }} & \multicolumn{4}{|c|}{ Well Grouping } \\
\hline & & & $\begin{array}{l}\text { First quarter, } \\
\text { annual, } \\
\text { semiannual }\end{array}$ & Second quarter & $\begin{array}{l}\text { Third quarter, } \\
\text { semiannual }\end{array}$ & Fourth quarter \\
\hline \multicolumn{7}{|c|}{ Upgradient perimeter wells (includes RCRA compliance wells) } \\
\hline $\begin{array}{ll}745 & 8 \\
833 & 8 \\
856 & 8 \\
859 & 8\end{array}$ & $\begin{array}{l}831 \\
846 \\
857 \\
860\end{array}$ & $\begin{array}{l}832 \\
855 \\
858\end{array}$ & $\begin{array}{l}\text { TAL/TCL } \\
\text { GC } \\
\text { PRC+RS } \\
\text { RCRA }\end{array}$ & RFI COC & $\begin{array}{l}\text { RFI COCs } \\
\text { RCRA }\end{array}$ & RFI COC \\
\hline \multicolumn{7}{|c|}{ Downgradient perimeter wells (includes RCRA compliance wells) } \\
\hline $\begin{array}{ll}835 & 8 \\
838 & 8 \\
841 & 8 \\
844 & 8 \\
1243\end{array}$ & $\begin{array}{l}836 \\
839 \\
842 \\
847\end{array}$ & $\begin{array}{l}837 \\
840 \\
843 \\
1242\end{array}$ & $\begin{array}{l}\text { TAL/TCL } \\
\text { GC } \\
\text { PRC+RS } \\
\text { RCRA }\end{array}$ & RFI COC & $\begin{array}{l}\text { RFI COC } \\
\text { PRC+RS } \\
\text { RCRA }\end{array}$ & RFI COC \\
\hline \multicolumn{7}{|c|}{ Downgradient perimenter wells (includes non-RCRA compliance wells) } \\
\hline $\begin{array}{l}4315 \\
4316 \\
4317\end{array}$ & & & $\begin{array}{l}\text { TAL/TCL } \\
\text { GC } \\
\text { PRC+RS }\end{array}$ & RFI COC & RFI COC & RFI COC \\
\hline \multicolumn{7}{|c|}{ Interior wells } \\
\hline $\begin{array}{l}648 \\
849 \\
852 \\
1039 \\
1233\end{array}$ & $\begin{array}{l}845 \\
850 \\
854 \\
1160 \\
123\end{array}$ & $\begin{array}{ll}848 \\
851 \\
1036 \\
6 & 1225 \\
7 & 1241\end{array}$ & $\begin{array}{l}\text { TAL/TCL } \\
\text { GC } \\
\text { PRC+RS }\end{array}$ & RFI COC & RFI COC & RFI COC \\
\hline
\end{tabular}

analytical suites are defined in Table 1.3.

- $\mathrm{TAL} / \mathrm{TCL}=$ Target Analyte List (Metals)/Target Compound List: CLP Volatiles, CLP Semivolatiles, CLP Pesticides/PCBs. 


\section{TASK INSTRUCTIONS}

This section identifies the specific groundwater quality sampling and analysis tasks to be performed to meet the objectives of the EMP. In all cases, fieldwork will be accomplished according to this SAP. Any deviations from this SAP will be documented on a WAG 6Monitoring Variance Request Form (MV-01) and approved before implementation. If for any reason a task is not completed, the reason also will be documented on a WAG 6-Monitoring Variance Request Form (MV-01). Any problem or corrective action taken also will be documented in the field logbook.

Groundwater samples will be collected by Energy Systems personnel from the 42 selected groundwater monitoring wells at the frequencies and for the analytes specified in the tables in Appendix B. These tables are organized on a quarterly basis and specify the analytical parameters for each well. The schedule is based on the assumption that an average of one well per working day will be sampled. Beginning with the first quarter sampling round, the field crew should proceed from well to well, completing water level measurements, purging, and sampling for each well before moving to the next well. Once each quarterly round of sampling has been completed, the field crew will not initiate the next quarterly sampling round until the beginning of the next quarter (three calendar months from the beginning of the preceding quarter).

A flowchart of the tasks to be conducted as part of this activity is displayed in Fig. 2.1. This flowchart graphically depicts the sequence in which the tasks will be conducted, the decision points associated with conducting the tasks, and when information will be recorded on the forms for data collection and management.

\subsection{GROUNDWATER LEVEL MEASUREMENTS}

Groundwater levels will be measured by Energy Systems personnel in each monitoring well before the well is purged. The objective for obtaining water level measurements is to determine the appropriate quantity of water to be purged from the well before sampling. To obtain groundwater level measurements, the following equipment is required:

- Rad gloves and other appropriate personal protective equipment (PPE) as specified by the Site H\&S Officer (SHSO) and/or Site Health Physicist (HP),

- photoionization detector (PID) or flame ionization detector (FID),

- water level indicator,

- field logbook, and

- WAG 6-Well Purging and Sampling Form (GWQ-01).

The water levels will be measured to the nearest $0.01 \mathrm{ft}$ using a water level indicator according to Environmental Surveillance Procedure ESP-003-022. The following guidelines will be adhered to when obtaining water level measurements.

- Don PPE as required. 





- Remove the cap from the well and allow it to vent for 3 to $5 \mathrm{~min}$.

- Check ambient air with a PID or FID; the sample task leader will note the reading.

- The Site Health and Safety Officer will check the atmosphere at the top of the well casing and the breathing zone with a PID or FID according to ESP-003-015. The sample task leader will note the reading.

- If contaminant levels in breathing zone atmosphere are not above ambient levels, lower the water level indicator probe into the well casing. If contaminant levels in breathing zone atmosphere are above ambient levels, the SHSO will contact Industrial Hygiene (IH) and work will stop at that location.

- When the alarm sounds and/or the indicator light on the side of the water level indicator reel illuminates, stop lowering the probe.

- Read the depth to water at the well casing survey mark and record it on the WAG 6-Well Purging and Sampling Form (GWQ-01) and in the field logbook.

- Remove the water level indicator from the well, wiping the tape clean as it is retrieved.

The water level indicator must be decontaminated at the site according to ESP-003-022 before subsequent use. The following guidelines shall be adhered to when decontaminating the water level indicator.

- Wipe the probe and the used portion of the water level indicator line with a paper towel that is moistened with distilled water and laboratory detergent.

- $\quad$ Rinse the probe and the washed portion of the line with distilled water.

- Allow the probe and line to air dry, or wipe dry with a paper towel.

\subsection{MONITORING WELL PURGING}

Groundwater monitoring wells will be purged and field parameters will be measured by Energy Systems personnel before obtaining samples. The objective for obtaining the field parameters and purging the monitoring wells is to ensure that fresh formation water is present in the wells during sampling.

Monitoring wells will be purged and measurements of the field parameters $\mathrm{(pH}$, temperature, turbidity, and conductivity) will be obtained in each well before sample collection according to ESP-003-012. To purge the wells and collect the field parameters, the following equipment is required:

- Rad gloves and other appropriate PPE,

- Geoguard $^{\text {mx }}$ or Well Wizard ${ }^{\text {mx }}$ displacement bladder pump (already installed in well),

- 26-L carboy,

- 32-gal plastic trash can,

- large plastic trash bag(s), 
- 55-gal drum(s),

| - plastic sheeting

- HORIBA Water Quality Checker,

- field logbook, and

- WAG 6-Well Purging and Sampling Form (GWQ-01).

The total volume of water to be purged, which is dependent upon the total depth of the well and the water level, will be determined according to ESP-003-022. The following guidelines shall be adhered to when determining the total volume of water to be purged from the wells.

- Subtract the water level from the total depth of the well to obtain the height of the water column.

- Multiply the height of the water column by the appropriate gal/ft multiplier on the WAG 6Well Purging and Sampling Form (GWQ-01) to obtain the volume (in gal) of water present in the well casing.

- Multiply the volume of water present in the well casing by three well volumes to obtain the total volume of water to be purged from the well.

Upon activation of the bladder pump, the pump purge flow rate will be determined to ensure that the appropriate volume of water is purged from the well. The purge flow rate will be determined by using the following equipment:

- 1-gal container or graduated bucket or beaker,

- watch or timer,

- field logbook, and

- WAG 6- Well Purging and Sampling Form (GWQ-01).

The purge flow rate will be determined by employing the following guidelines.

- Place plastic sheeting on ground away from well area to place clean, unused equipment on, if needed.

- Place a container in position beneath the pump discharge inside the 32-gallon trash can, to collect the well purge water.

- Note the beginning time (in minutes) when the first stream of pump discharge in water enters the container.

- Allow the container to fill for at least 30 to 60 seconds.

1 - Note the ending time (in minutes) when the last stream of pump discharge inside water enters the container. Determine the time (in minutes) of the discharge by subtracting the beginning time from the ending time.

- Determine the volume of water present in the container (in milliliters). 
- Use the following equation to determine the pump purge rate in milliliters per minute (mL/min.):

$$
\mathrm{mL} / \mathrm{min} .=\frac{\text { Volumeof watercollected }(\text { in milliliters })}{\text { Time }(\text { in minutes })}
$$

- Document the purge rate in the WAG 6-Well Purging and Sampling Form (GWQ-01) and field logbook. Note that the subsequent sampling flow rate will be moderated so that it does not exceed the calculated purge rate.

The wells will be purged by adhering to the following guidelines.

- Don PPE as required by the SHSO and/or Site Health Physicist before beginning work.

- Activate the displacement pump and begin purging the appropriate volume of water from the well into a 55-gal drum or a $26-\mathrm{L}$ carboy placed in a plastic 32-gal trash can.

- Purge a total of three casing volumes from the well, or purge the well to dryness.

- Record the total volume of water purged from the well and the field parameter data on the WAG 6-Well Purging and Sampling Form (GWQ-01) and in the field logbook.

Purge water contained in the 26-L carboy and any overflow contained in the 32-gal plastic trash can is poured into a 55-gal drum. The well purge water will be stored in the 55-gal drum until laboratory results indicate the appropriate method of disposal, according to Sect. 5.

While purging the well, measurements of $\mathrm{pH}$, temperature, turbidity, and conductivity will be obtained according to ESP-003-012 with a HORIBA Water Quality Checker. The field parameter measurements will be obtained according to the following guidelines. Before obtaining the parameter measurements, the HORIBA Water Quality Checker will be calibrated according to ESP-003-012.

- Measure field parameters ( $\mathrm{pH}$, temperature, turbidity, and conductivity) while the water is being purged from the well, and record after each purge volume.

- Immerse the probe into a sample of the well purge water.

- Obtain the parameter value from the digital or analog readout of the field measurement instrument.

- Record the obtained parameter value on the WAG 6-Well Purging and Sampling Form (GWQ-01) and in the field logbook. 


\subsection{GROUNDWATER SAMPLING}

Groundwater samples will be collected as grab samples from each of the selected monitoring wells. Before sampling the well, measurements of $\mathrm{pH}$, temperature, turbidity and conductivity will be taken according to ESP-003-012 with a HORIBA Water Quality Checker. These parameters, plus turbidity, will be taken at the beginning and conclusion of sampling. Turbidity is measured with the HORIBA Water Quality Checker, using ESP-003-012. To collect groundwater samples, the following equipment is required:

- surgical gloves and other appropriate PPE;

- plastic sheeting;

- sample containers, prewashed;

- sample labels;

- HORIBA Water Quality Checker;

- bar coding equipment;

- sample containment cooler;

- Blue ice;

- WAG 6-Well Purging and Sampling Form (GWQ-01);

- sample preservatives;

- sample bags;

- field logbook;

- chain-of-custody form (see Appendix A);

- custody seals; and

- in-line $0.45-\mu \mathrm{m}$ filters.

Groundwater samples will be collected by Energy Systems personnel according to ESP-003-022. Before obtaining groundwater samples, the sampling flow rate will be determined and adjusted (if necessary) to ensure that the sampling rate is less than the purge rate. When sampling volatiles and semivolatiles, the sampling rate will not exceed 100 to $200 \mathrm{~mL} / \mathrm{min}$. The sampling rate will be determined by using the following equipment:

$$
\rightarrow
$$

- graduated cylinder,

- watch or timer, and

- WAG 6-Well Purging and Sampling Form (GWQ-01) and field logbook.

The sampling flow rate will be determined by employing the following guidelines.

- Adjust the pump discharge rate downward (if necessary).

- Place the graduated cylinder in position beneath the pump discharge to collect the well purge water.

- Note the beginning time (in minutes) when the first stream of pump discharge water enters the cylinder.

- Note the ending time (in minutes) when the last stream of pump discharge water enters the cylinder. Determine the time (in minutes) of the discharge by subtracting the beginning time from the ending time. 
- Use the following equation to determine the pump sampling flow rate in milliliters per minute (mL/min):

$$
\mathrm{mL} / \mathrm{min}=\frac{\text { Volume of water collected }(\text { in milliliters })}{\text { Time }(\text { in minutes })}
$$

- Determine whether the sampling flow rate is less than the purge rate. The sampling rate must not exceed the purge rate.

- If the sampling flow rate is equal to or greater than the purge rate, then adjust the pump discharge rate down accordingly, and repeat the previous procedure.

- When the sampling flow rate is appropriate for collection of samples (less than purge rate), document it in the WAG 6-Well Purging and Sampling Form (GWQ-01) and field logbook.

The following guidelines should be followed when collecting groundwater samples.

- Don PPE as required by the SHSO before beginning work.

- Activate the displacement pump and begin pumping water from the well. The pumped water should be directed into the carboy or drum when samples are not actively being collected.

- Collect groundwater samples in the sample container directly from the discharge of the bladder pumps.

- Measure field parameters ( $\mathrm{pH}$, temperature, turbidity and conductivity) at the beginning and end of sample collection.

- Complete the well purging and sampling summary form and sample labels in the field while working. Samples will be labeled in accordance with WAG 6-FOP 9.

- Measure field parameters ( $\mathrm{pH}$, temperature, turbidity, conductivity, and turbidity) at completion of sample collection.

- Filter the samples to be analyzed for ICP metals.

- Add the appropriate preservatives to the samples if the sample containers are not prepreserved (Table 2.1).

- Place the samples in an insulated cooler containing Blue ice, and transport them to the appropriate location for packaging and shipping.

- Use procedure ESP 505 when samples are packaged for shipment.

- Complete chain-of-custody forms and submit the samples to the appropriate analytical chemistry laboratory for analysis. 
Table 2.1. Sample containers, preservatives, and holding times for groundwater samples from groundwater quality monitoring wells in WAG 6

\begin{tabular}{|c|c|c|c|c|c|c|}
\hline Parameter ${ }^{a}$ & $\begin{array}{c}\text { Analytical } \\
\text { method }\end{array}$ & $\begin{array}{c}\text { Container } \\
\text { type }^{b}\end{array}$ & $\begin{array}{c}\text { Container } \\
\text { volume }\end{array}$ & $\begin{array}{c}\text { Number of } \\
\text { containers } \\
\text { per site }\end{array}$ & Preservation & $\begin{array}{l}\text { Maximum } \\
\text { holding time }\end{array}$ \\
\hline CLP volatiles & CLP & G-vial, T-lined & $40 \mathrm{~mL}$ & 2 & $\mathrm{HCl} \mathrm{pH}<2,4^{\circ} \mathrm{C}$ & $14 \mathrm{~d}$ \\
\hline CLP semivolatiles & CLP & Amber-G & $1 \mathrm{~L}$ & 1 & $4^{\circ} \mathrm{C}$ & $7 d$ \\
\hline CLP Pesticides/PCBs & CLP & Amber-G & $1 \mathrm{~L}$ & 1 & $4^{\circ} \mathrm{C}$ & $7 \mathrm{~d}$ \\
\hline Herbicides & CLP & Amber-G & $1 \mathrm{~L}$ & 1 & $4^{\circ} \mathrm{C}$ & $7 d$ \\
\hline CLP metals & CLP & $\mathbf{P}$ & 1L Poly & 1 & $\mathrm{HNO}_{3} \mathrm{pH}<2,4^{\circ} \mathrm{C}$ & $180 \mathrm{~d}$ \\
\hline ICP metals & ICP & $\mathbf{P}$ & $1 \mathrm{~L}$ Poly & 1 & $\mathrm{HNO}_{3} \mathrm{pH}<2,4^{\circ} \mathrm{C}$ & $180 \mathrm{~d}$ \\
\hline Gross alpha & 900 & $\mathbf{Q}$ & $500 \mathrm{~mL}$ & 1 & $\mathrm{HNO}_{3} \mathrm{pH}<2,4^{\circ} \mathrm{C}$ & $180 \mathrm{~d}$ \\
\hline Gamma scan & 901.1 & $\mathbf{Q}$ & 1 L Poly & 1 & $\mathrm{HNO}_{3} \mathrm{pH}<2,4^{\circ} \mathrm{C}$ & $180 \mathrm{~d}$ \\
\hline Tritium & 906 & $\mathbf{P}$ & $500 \mathrm{~mL}$ Glass & 1 & $4^{\circ} \mathrm{C}$ & $180 \mathrm{~d}$ \\
\hline Strontium-90 & 905 & $\mathbf{P}$ & $1 \mathrm{~L}$ & 1 & $\mathrm{HNO}_{3} \mathrm{pH}<2,4^{\circ} \mathrm{C}$ & $180 \mathrm{~d}$ \\
\hline Anions & 300.0 & $\mathbf{P}$ & IL Poly & 1 & $4^{\circ} \mathrm{C}$ & $28 \mathrm{~d}$ \\
\hline DOC/DIC & $415.1 / 9060$ & $\mathbf{P}$ & $500 \mathrm{~mL}$ Poly & 1 & $\mathrm{H}_{2} \mathrm{SO}_{4} \mathrm{pH}<2,4^{\circ} \mathrm{C}$ & $28 \mathrm{~d}$ \\
\hline Alkalinity & 310.1 & $\mathbf{P}$ & $100 \mathrm{~mL}$ Poly & 1 & $4^{\circ} \mathrm{C}$ & $14 \mathrm{~d}$ \\
\hline
\end{tabular}

“CLP - Contract Laboratory Program, PCB = polychlorinated biphenyl, DOC/DIC = dissolved organic carbon/dissolved inorganic carbon ${ }^{\mathrm{C}} \mathrm{G}=$ Glass, $\mathrm{T}=$ Teflon, $\mathrm{P}=$ High density polyethylene, $\mathrm{Q}=$ Cubitainer 
In some cases, the volume of groundwater in a well may not be sufficient to obtain the desired number of samples. In these cases, sample collection priority will be in the following order.

1. Volatiles

2. Radionuclides, including tritium

3. Semivolatiles

4. Dissolved organic carbon

5. Dissolved inorganic carbon

6. Metals, inductively coupled plasma/mass spectrometry

7. Metals

8. Anions

9. Alkalinity 
. 


\section{QUALITY ASSURANCE/QUALITY CONTROL REQUIREMENTS}

\subsection{OVERVIEW}

This section identifies QA/QC aspects of the Quality Assurance Plan for Characterization and Monitoring Activities at Waste Area Grouping 6, Oak Ridge National Laboratory, Oak Ridge, Tennessee (CDM Federal 1993) that are required to implement the EMP and this SAP. Subjects addressed in this section include, but are not limited to, monitoring program organization and personnel responsibilities, documentation procedures and protocols, sampling and monitoring QC requirements, decontamination procedures, and equipment calibration and maintenance. The QA/QC considerations presented in this section have been developed to ensure that the data generated during all phases of the EMP will be of known quality and legally defensible.

Work on this assignment will be performed in accordance with the following:

- Environmental Restoration Quality Program Plan, ES/ER/TM-4/R4 (Energy Systems 1993);

- Interim Guidelines and Specifications for Preparing Quality Assurance Project Plans, QAMS-005/80 (EPA 1983);

- Quality Assurance Program Requirements for Nuclear Facilities, ASME NQA-1 (ASME 1989);

- Quality Assurance Project Plan for the Environmental Monitoring Program in Waste Area Grouping 6 at Oak Ridge National Laboratory, Oak Ridge, Tennessee, DOE/OR/011193\&D1 (DOE 1993b); and

- WAG 6 Field Operations Procedures Manual (CDM Federal 1993)

This SAP has been reviewed for QA/QC requirements by the Contract QA Manager, who will maintain QA oversight for the duration of the project. In addition, all deliverables will be subject to technical review by CDM Federal Programs Corporation (CDM Federal) technical specialists. All deliverables presenting measurement data will be reviewed by the CDM Federal QA staff. A description of the project Data Quality Objectives can be found in the EMP.

\subsection{MONITORING PROGRAM ORGANIZATION}

The EMP personnel comprise a sub-task team of the Monitoring and Laboratory Analysis Group, identified in the WAG 6 EMP (DOE 1993a). The principal contractor personnel assigned to conduct the WAG 6 EMP field activities are:

- $\quad$ Mitch Goldberg (Project Manager)

- David Johnson (QA Specialist)

- Donnie McCurry [Field Task Manager (FTM)]

- David Fugate [Groundwater Quality Sample Task Leader (STL)]

- Michael Charko (Field Technician)

- Richard Stout (Field QC Coordinator) 
Figure 3.1 shows the project organization, reporting relationships, and lines of authority for this project. General responsibilities are discussed in the following subsections. Other personnel will be assigned as necessary. The responsibilities of key team members are described in Table 3.1 .

\subsection{FIELD DOCUMENTATION}

Field documentation shall consist of:

- one master site logbook to be maintained at field headquarters,

- an equipment maintenance and calibration logbook,

- an activity-specific field logbook,

- a telephone logbook,

- project- and activity-specific field forms (Appendix A),

- chain-of-custody forms,

- sample labels, and

- bar code labels.

All documentation must be completed in waterproof black ink, and corrections must be marked through with a single line, dated, and initialed. Handwritten documents must be legible. Table 3.2 displays where, and what kind of, information must be recorded.

\section{Field Documentation Forms}

Field documentation forms will be the primary documentation of all EMP field activities. The following forms are to be used for the specific activities addressed in this SAP:

- WAG 6-Well Purging and Sampling Form (GWQ-01),

- WAG 6-Monitoring Variance Request Form (MV-01),

- WAG 6-Record of Repair Form (RF-01),

- WAG 6-Chain-of-Custody Form (COC-01),

- WAG 6-Weekly Activity Schedule (WAS-01),

- WAG 6-Field Collection Task Map (FCTM-01), and

- WAG 6-Field Activity Sheet (FAS-01).

These forms are located in Appendix A.

Any information pertinent to the current field activity or field condition that is not requested on the field documentation form should also be entered in the "Comments" section of the form and in the field logbook. The forms used at each site will be numbered sequentially, using bar codes. The form bar code label will be attached to the bottom right of the form, and also entered into the field logbook. In addition, any charts, oversize pages, and other printed material (e.g., runoff hydrographs, sample times) pertinent to current field activities will be securely attached to the corresponding field documentation form. The form number of the corresponding field documentation form must be written somewhere on the attached material and contained in the notebook. On a daily basis, completed forms will be forwarded to the FTM, who will review the forms and forward them to the DM for entry into the data base. 


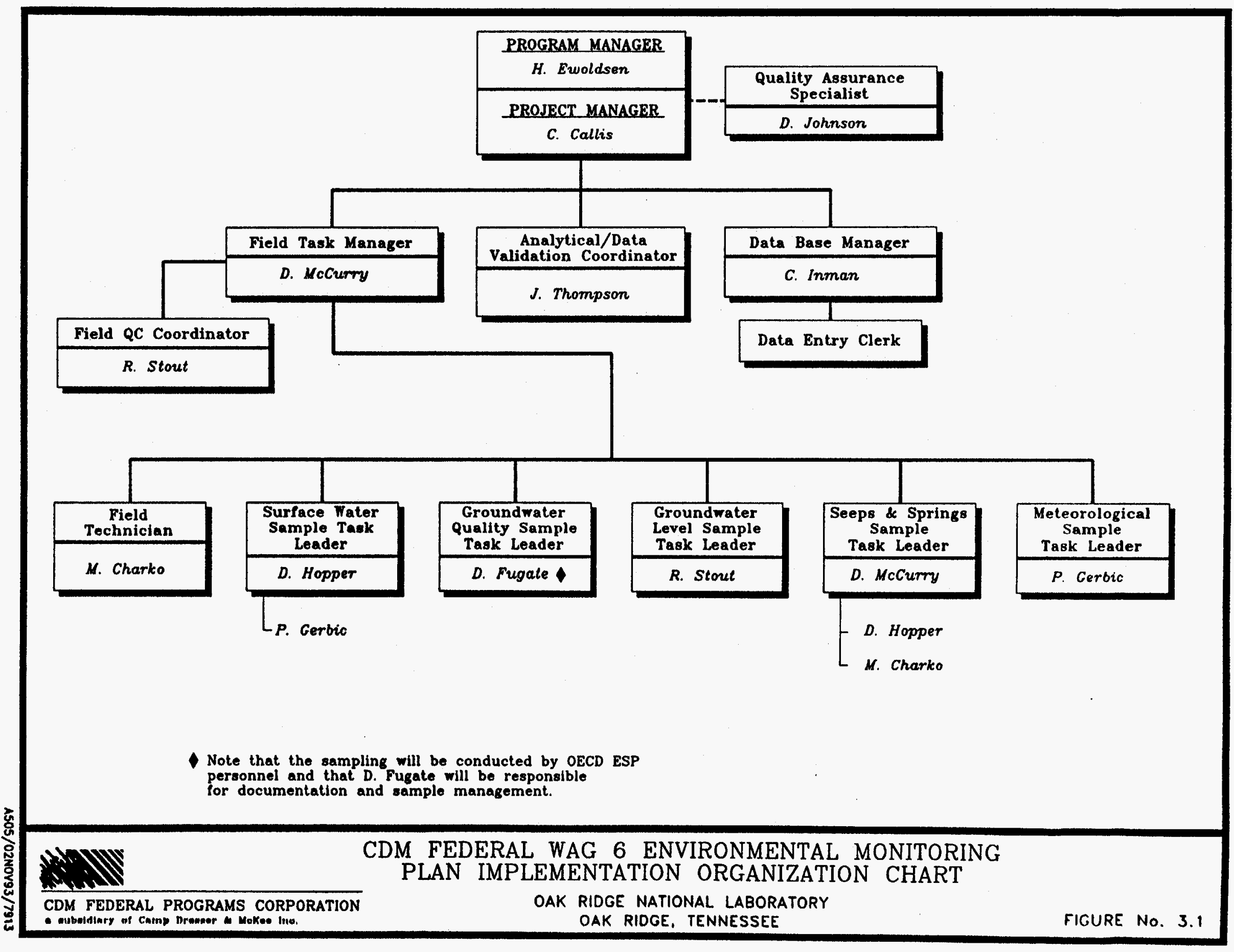


Table 3.1. General responsibilities of WAG 6 EMP principal contractor personnel

\begin{tabular}{|c|c|}
\hline Position & Responsibilities \\
\hline $\begin{array}{l}\text { Project } \\
\text { Manager }\end{array}$ & $\begin{array}{l}\text { - Verifying that all appropriate QA requirements, as specified in the WAG } 6 \text { QA Plan } \\
\text { and in this document, are met in all field monitoring and laboratory activities; } \\
\text { consulting with the WAG } 6 \text { Program Manager and appropriate EMP QA authorities } \\
\text { on all quality-related matters; } \\
\text { investigating field- and laboratory-related quality problems (e.g., out-of-control } \\
\text { events), determining their root causes, proposing solutions, implementing corrective } \\
\text { actions, and obtaining the concurrence of the WAG } 6 \text { Program Manager and QA } \\
\text { authorities on the appropriateness of any corrective action; } \\
\text { - submitting any proposed changes to the SAP, in the form of a WAG } 6 \text { - Monitoring } \\
\text { Variance Request Form (MV-01), to the WAG } 6 \text { Program Manager for approval; } \\
\text { maintaining custody of all original and copied EMP monitoring documentation; } \\
\text { - reviewing all field data and documentation and all laboratory data for completeness } \\
\text { and adherence to QA protocols; } \\
\text { submitting all field data and documentation and all laboratory data to the WAG } 6 \\
\text { Program Manager for review; and } \\
\text { developing, gaining approval for, and implementing any cost-effective quality } \\
\text { improvements. }\end{array}$ \\
\hline
\end{tabular}

Field Task Manager
- Implementing relevant requirements contained in the governing documents and plans;

- ensuring and documenting that all field and laboratory personnel are properly informed and trained as specified in this SAP;

- ensuring that there are an adequate number of properly trained personnel for implementation of groundwater quality monitoring activities;

- ensuring that all equipment (including backup equipment) necessary for groundwater quality monitoring is available for immediate use;

- keeping well informed of scheduled interim remedial action and site upgrade construction activities, especially when such activities may hamper groundwater quality monitoring activities or affect data quality objectives and/or QA objectives;

- initiating stop-work actions when the severity of conditions adverse to quality warrants immediate action;

- managing or performing inspections and calibrations, and maintaining accurate documentation of all site equipment calibration and servicing activities;

- managing or performing field monitoring activities, and ensuring that all such activities are performed and documented in accordance with QA protocols and approved procedures;

- maintaining custody of all samples collected at the site until submitted to laboratory personnel;

- submitting all field documentation and electronic site data to the Project Manager for review; and 
Table 3.1 (continued)

\begin{tabular}{|c|c|}
\hline Position & Responsibilities \\
\hline & $\begin{array}{l}\text { - keeping the Project Manager informed of all site activities and quality-related } \\
\text { problems. }\end{array}$ \\
\hline $\begin{array}{l}\text { QA } \\
\text { Specialist }\end{array}$ & $\begin{array}{l}\text { - } \\
\text { - } \\
\text { identifying project QA requirements and preparing QA procedures as required; } \\
\text { - } \text { reviewing and approving the SAP and all subsequent changes to the SAP; } \\
\text { - conducting or arranging scheduled audits or surveillances of task activities; } \\
\text { - evaluating quality performance data from quality investigations, audits, and } \\
\text { reviews; } \\
\text { - preparing monthly QA summary reports for corporate management; } \\
\text { - conducting or arranging QA training; } \\
\text { - tracking the implementation of QA requirements in this plan and consulting } \\
\text { periodically with the Project Manager; } \\
\text { tracking reports on conditions adverse to quality, reviewing corrective action, and } \\
\text { tracking completion; and } \\
\text { initiating, reviewing, and following up on corrective actions as necessary. }\end{array}$ \\
\hline $\begin{array}{l}\text { Field QC } \\
\text { Coordinator }\end{array}$ & $\begin{array}{l}\text { - Implementation and documentation of training requirements, } \\
\text { - QC review and verification of field forms and logbooks, } \\
\text { - QC review of environmental and QC samples, and } \\
\text { - verification of proper FOP usage. }\end{array}$ \\
\hline $\begin{array}{l}\text { Field } \\
\text { Technician }\end{array}$ & $\begin{array}{l}\text { - Maintenance and calibration of portable equipment, } \\
\text { - inventory of supplies, } \\
\text { - } \quad \text { sampling kit preparation, } \\
\text { - } \quad \text { sample shipping, } \\
\text { - } \quad \text { waste management, and } \\
\text { - proper documentation of all field activities. }\end{array}$ \\
\hline $\begin{array}{l}\text { Sample } \\
\text { Task Leader }\end{array}$ & $\begin{array}{l}\text { - Documentation of all field activities, } \\
\text { - sample collection coordination with Energy Systems personnel, } \\
\text { - monitoring and data acquisition activities, and } \\
\text { - waste management. }\end{array}$ \\
\hline
\end{tabular}


Table 3.2. Types of WAG 6 EMP field documentation and the information required for each

\begin{tabular}{|c|c|}
\hline Field documentation & Information \\
\hline Site Logbook & $\begin{array}{l}\text { - A list of all field logbooks; } \\
\text { - daily temperature, weather conditions, and names and titles of } \\
\text { personnel present; } \\
\text { - name, title, organization, and purpose of site visitors; } \\
\text { - outline of daily activities; } \\
\text { - problems, their final resolution, and anticipated impact on the field } \\
\text { investigation; } \\
\text { - field changes or variances; } \\
\text { - a record of samples collected and shipped; } \\
\text { - a record of equipment decontamination. }\end{array}$ \\
\hline $\begin{array}{l}\text { Equipment } \\
\text { Maintenance and } \\
\text { Calibration Logbook }\end{array}$ & $\begin{array}{l}\text { - Equipment name, serial number, and identification (ID) number, } \\
\text { - date of each calibration event, } \\
\text { - identity of person performing calibration, and } \\
\text { - calibration settings and values. }\end{array}$ \\
\hline Field Logbooks & $\begin{array}{l}\text { Date and time task started; weather conditions; and names of } \\
\text { personnel performing the task; } \\
\text { - a description of site activities in specific detail; } \\
\text { - a description, in detail, of any field test(s) (and results); } \\
\text { - a description of environmental and QC samples collected; } \\
\text { - a list of the time, equipment type and serial or ID number, and } \\
\text { procedure followed for decontamination activities; } \\
\text { - a list of equipment failures or breakdowns; and } \\
\text { - a description of calibration activities in the field. }\end{array}$ \\
\hline Telephone Logbook & $\begin{array}{l}\text { - } \quad \text { Date of call, } \\
\text { - } \quad \text { time of call, } \\
\text { - } \text { whether incoming or outgoing, } \\
\text { - participating parties, and } \\
\text { - } \quad \text { subject and pertinent information. }\end{array}$ \\
\hline
\end{tabular}




\subsection{SAMPLE IDENTIFICATION AND LABELING}

Labeling of all samples shall be performed in accordance with WAG 6-FOP 9. The following information must be recorded on the sample label:

- site name,

- unique sample ID number,

- date and time of sample collection,

- matrix,

- name of sampler,

- sample preservation,

- type of analyses to be conducted, and

- cleaning lot number.

All labels must be waterproof and preprinted or completed in permanent ink. A bar code label will also be attached, then scanned for entry into the database. An example sample label is included in Appendix A. Preprinted sample labels will be provided to the Field Technician in advance of scheduled sampling.

\subsection{CHAIN OF CUSTODY}

Preprinted chain-of-custody forms will be provided after the scheduled sampling. Sample possession must be traceable and shall be maintained in accordance with ESP-500, "Manual Chain-of-Custody Procedures." To track sample possession, an official documented chain-ofcustody form (see Appendix A) shall be maintained for each sample. A sample is in custody if one or more of the following criteria are met:

- it is in the possession of a sampling team member,

- it is in a sampling team member's view after being in possession, or

- it is in a designated secure area.

The following information will be recorded on the completed chain-of-custody form:

- $\quad$ project name,

- signature of sampler,

- sampling station,

- unique sample number,

- date and time of collection,

- grab or composite designation,

- matrix (i.e., groundwater),

- preservatives, and

- signatures of individual involved in sample transfer.

Chain-of-custody forms will be placed in a plastic cover and taped inside the shipping container used for sample transport from the field to the laboratory. When samples are relinquished to a shipping company for transport, the tracking number from the shipping bill/receipt will be recorded on the chain-of-custody form and in the field logbook. Individuals receiving samples will sign, date, and note the time of receipt on the chain-of-custody form. 


\subsection{ACTIVITY-SPECIFIC QUALITY ASSURANCE/QUALITY CONTROL REQUIREMENTS}

See Table 3.3 for QC sample types, description, and generic frequencies. Refer to the tables in Appendix B for activity-specific QC samples and collection numbers. Note that no rinseate or field blank QC samples are being collected. Since all the sampling equipment is dedicated, no decontamination of the sampling equipment will be conducted; therefore, no QC samples associated with evaluating the decontamination process will be required. The order of QC sample collection is organized so that no QC samples will be obtained from a specific well more than once during a four-quarter monitoring cycle.

Table 3.3. Quality control sample types and frequencies for groundwater quality sampling and analysis

\begin{tabular}{|c|c|}
\hline QC sample types & Frequencies \\
\hline $\begin{array}{l}\text { Field Duplicates are collected sequentially with each } \\
\text { sample into separate containers. Each sample is } \\
\text { labeled according to the activity-specific labeling } \\
\text { specifications, so that the identity of one of the } \\
\text { samples as a duplicate is not obvious from the label. }\end{array}$ & 1 duplicate/10 wells \\
\hline $\begin{array}{l}\text { Matrix Spike/Matrix Spike Duplicates are samples } \\
\text { (one sample and a duplicate) collected in the field, } \\
\text { labeled as an MS and an MSD. }\end{array}$ & $1 \mathrm{MS} / \mathrm{MSD} / 20$ wells \\
\hline $\begin{array}{l}\text { Trip blanks consist of } 40-\mathrm{mL} \text { vials filled with } \\
\text { organic-free distilled/deionized water. Trip blanks } \\
\text { are made up at the point of origin of the sampling } \\
\text { team at the beginning of the day's sampling } \\
\text { activities, and must be included in each cooler } \\
\text { containing samples to be analyzed for volatile } \\
\text { organic compounds. }\end{array}$ & $\begin{array}{l}1 / \text { cooler containing samples to be analyzed for } \\
\text { volatile organic compounds }\end{array}$ \\
\hline
\end{tabular}




\section{HEALTH AND SAFETY CONSIDERATIONS}

The provisions of the project H\&S Plan are mandatory for all personnel assigned to the program. In no case may work be performed in a manner that is inconsistent with the intent and cautions expressed in the project H\&S Plan. All field personnel will be properly trained in H\&S regulations associated with handling hazardous materials and the safe operation of sampling equipment. As specified in 29 CFR 1910.120, all field personnel will have attended Occupational Safety and Health Administration (OSHA) 40-h hazardous waste worker training.

In general, personnel will work in groups or pairs. However, personnel will perform some work activities independently of other members of the WAG 6 field team. At these times, personnel will abide by the "buddy system." Each member of the WAG 6 field team will be responsible for keeping track of personnel working independently. Before leaving a radioactive or muddy area, all personnel and conveyed equipment will be checked with a beta-gamma meter for evidence of radiological contamination. Personnel will take precautions to help prevent contact with hazards identified in the project H\&S Plan.

The SHSO and Site Health Physicist shall specify the PPE required for site activities, tasks, and work zones. This specification shall be based on possible site contaminants, OSHA guidelines, and chemical and radiological hazards information. The SHSO and/or the Site Health Physicist shall train all site personnel in PPE donning and doffing procedures before beginning any site activities. The task instructions in Appendix $C$ address activity- and location-specific $\mathrm{H} \& \mathrm{~S}$ issues. 



\section{WASTE MANAGEMENT}

The WAG 6 EMP Waste Management Plan (WMP) states that CDM Federal, as waste generator, will perform waste segregation, packaging, labeling, and transportation as required during the project. [Waste Management Operations (WMO) will transport liquid waste from the temporary waste storage area to the appropriate facility.] CDM Federal is not responsible for final disposition of waste.

Anticipated wastes from groundwater quality sampling activities include decontamination fluids, purge water, PPE, sampling residuals, and various other trash items such as plastic sheeting.

\subsection{ORGANIZATIONAL RESPONSIBILITIES}

The following personnel will be responsible for various aspects of WAG 6 waste management.

\section{Laboratory Certification Official}

The Laboratory Certification Official has the following responsibilities:

- implementing and managing the ORNL Solid Low-Level Waste (SLLW) Certification program,

- reviewing and approving project WMPs and WMP checklists, and

- providing direction if an unforeseen waste situation is encountered.

\section{Generator Certification Official}

The Generator Certification Official (GCO) has the following responsibilities:

- serving as interface between the project, the ORNL Laboratory Certification Official, and the ORNL WMO in addressing generator problems and waste certification requirements;

- initiating preparation of the Waste Pickup Request Form;

- certifying that the waste was packaged in accordance with the ORNL waste area criteria, the ORNL SLLW certification program, and SLLW QA Plan requirements;

- making arrangements with WMO for pickup and transfer of waste packages to the designated storage or treatment facility; and

- assuming other duties as specified in the WMP.

\section{Field Task Manager}

The Field Task Manager has the following responsibilities:

- ensuring that site personnel follow the WMP, 
- coordinating with Health Physics (HP) and IH, and

- assuming responsibility for transportation of waste as required.

Sample Task Leader

As the generator, the Sample Task Leader has the following responsibilities:

- properly containerizing, packaging, and segregating all waste generated as part of the project;

- maintaining interface with the FTM to ensure that any issues pertaining to SLLW characterization are promptly brought to the attention of the responsible individuals and that any new certification requirements are promptly instituted;

- assisting the GCO with the preparation of the Waste Pickup Request Form and the Container Packing List; and

- assuming other duties as specified in the project WMP.

Health Physics and Industrial Hygiene Personnel

HP and IH personnel are responsible to conduct surveys as necessary to determine if waste contains RCRA-regulated or radiologically contaminated materials.

\subsection{GUIDANCE DOCUMENTS}

The following documents will provide guidance for waste management activities conducted during the implementation of the WAG 6 EMP.

- WAG 6 Project WMP,

- "Waste Management" (ESP-1000),

- Waste Acceptance Criteria for Radiological Solid Waste Disposal (WMRA-WMPC-203),

- ORNL Liquid Waste Treatment Systems Waste Acceptance Criteria (WM-WMCO-201),

- Waste Item Description (UCN-2109) Form User Instructions,

- Container Packing List (TX-5749) Form User Instructions, and

- Management of Investigation-derived Waste During Site Investigations (EPA 1991).

\subsection{WASTE CHARACTERIZATION/SEGREGATION}

When waste is first generated, it will be containerized. Table 5.1 shows the various categories into which waste will be segregated for this project, the criteria for segregation, and packaging requirements. 
Table 5.1. WAG 6 waste management

\begin{tabular}{|c|c|c|c|c|c|}
\hline $\begin{array}{r}\text { Type } \\
\text { of waste }\end{array}$ & $\begin{array}{l}\text { Category } \\
\text { of waste }\end{array}$ & $\begin{array}{c}\text { Segregation } \\
\text { requirements }\end{array}$ & $\begin{array}{c}\text { Packaging } \\
\text { requirements }\end{array}$ & $\begin{array}{c}\text { Accumulation/ } \\
\text { staging area }\end{array}$ & $\begin{array}{c}\text { Final } \\
\text { disposal }^{b}\end{array}$ \\
\hline \multirow[t]{3}{*}{ Purge water } & 22 & $\begin{array}{l}\text { One drum per well; segregation based } \\
\text { on analytical results }\end{array}$ & 55-gal drums & At well; diked area available & $\begin{array}{l}\text { Release at point of origin or on } \\
\text { ground as investigation-derived }\end{array}$ \\
\hline & 24 & $\begin{array}{l}\text { One drum per well; segregation based } \\
\text { on analytical results }\end{array}$ & 55-gal drums & At well & \\
\hline & 25 & $\begin{array}{l}\text { One drum per well; segregation based } \\
\text { on analytical results }\end{array}$ & 55-gal drums & At well & \\
\hline \multirow[t]{2}{*}{ Returned sample water } & 22 & Sample analytical results & 55-gal drums/carboys & $\begin{array}{l}\text { Diked area by entrance or } \\
\text { GCO-designated area }\end{array}$ & Process waste treatment plant \\
\hline & 24 & Sample analytical results & 55-gal drums/carboys & $\begin{array}{l}\text { Diked area by entrance or } \\
\text { GCO-designated area }\end{array}$ & $\begin{array}{l}\text { Nonradiological process waste } \\
\text { treatment plant }\end{array}$ \\
\hline Used sample bottles ${ }^{c}$ & - & - & - & - & $\begin{array}{l}\text { Cleaned by laboratory and retumed } \\
\text { for reuse }\end{array}$ \\
\hline \multirow{3}{*}{$\begin{array}{l}\text { Miscellaneous trash } \\
\text { (personal protective } \\
\text { equipment, plastics, } \\
\text { paper) }\end{array}$} & 5 & $\begin{array}{l}\text { No } \alpha \text { or } \beta / \gamma \\
\text { no volatiles }\end{array}$ & $\begin{array}{l}\text { Plastic bags in garbage } \\
\text { cans at site }\end{array}$ & $\begin{array}{l}\text { Green dumpster adjacent to } \\
\text { personnel trailers }\end{array}$ & Y-12 landfill \\
\hline & 8 & Suspected $\alpha$ or $\beta / \gamma$ but no volatiles & $\begin{array}{l}\text { Package per Solid Waste } \\
\text { Storage Area (SWSA) } 6 \\
\text { Waste Area Criteria } \\
\text { instructions } \\
\text { (WMRA-WMPC-203) }\end{array}$ & GCO-designated area & $\begin{array}{l}\text { Site designated by Waste } \\
\text { Management Operations }\end{array}$ \\
\hline & 14 & $\begin{array}{l}\alpha \text { or } \beta / \gamma \\
\text { no volatiles }\end{array}$ & $\begin{array}{l}\text { Package per SWSA } 6 \\
\text { Waste Area Criteria } \\
\text { instruction (WMRA- } \\
\text { WMPC-203) }\end{array}$ & GCO-designated area & SWSA S-box compactor \\
\hline \multirow[t]{3}{*}{ Decontamination water } & 22 & $\begin{array}{l}\text { Based on procedure: solvent, acid, } \\
\text { etc; } \alpha \text { or } \beta / \gamma\end{array}$ & Arrange with LGWOD & Carboy & Process waste treatment plant \\
\hline & 24 & $\begin{array}{l}\text { Based on procedure: solvent, acid, } \\
\text { etc; no } \alpha \text { or } \beta / \gamma\end{array}$ & Arrange with LGWOD & Carboy & $\begin{array}{l}\text { Nonradiological waste treatment } \\
\text { plant }\end{array}$ \\
\hline & 25 & $\begin{array}{l}\text { No hazardous substance used in } \\
\text { decontamination; no } \alpha \text { or } \beta / \gamma\end{array}$ & arrange with LGWOD & Carboy & Storm sewer system \\
\hline
\end{tabular}

" Categories of waste as delineated by the Project WMP.

- According to Tables 3.2 and 3.3 in the Project WMP.

- Although these arae called out in the Project WMP and will be generated, it is unlikely that they will be returned to the site. 


\subsubsection{Solid Waste}

As it is generated (when possible), or at the end of each day, HP personnel will use portable alpha and beta/gamma detectors to monitor the material generated in the controlled zone for the presence of radioactivity. They will designate waste as being "Clean," "Very Low Activity," or "Low Level" Waste. Solid waste generated from radioactive zones will be controlled in the radioactive zones.

HP personnel will be responsible for scanning all waste entering and leaving WAG 6 . If the waste is within Energy Systems standards, the waste will be issued a "green tag," signifying that it is "clean" of radioactive contamination. An on-site dumpster adjacent to personnel trailers will be available for "clean" waste generated on-site, such as office papers.

\subsubsection{Liquid Waste}

Purge water will be considered investigation-derived waste according to Sect. 5.3 of the project WMP, and may be handled according to the guidelines in Management of Investigationderived Waste During Site Investigations (EPA 1991). However, if the contamination levels indicated by sample results exceed defined limits, the purge water (and returned sample water, if any) will not be managed as investigation-derived waste.

Following early interim guidance from the Environmental Compliance Section of the OECD, results from radiological analyses are compared with values that are $25 \%$ of the DOE DCGs for radionuclides. Drinking water standards were judged to be overly restrictive for this application, since it is highly unlikely that anyone will use WAG 6 groundwater as drinking water. The full DOE DCG, associated with an annual effective dose equivalent of $100 \mathrm{mrem}$, was deemed too lenient. A compromise value of $25 \%$ of the DCG is used in ESP checks. The associated dose of 25 mrem is comparable with Nuclear Regulatory Commission land disposal performance criteria and with DOE Order 5820.2A. Radiological analytes commonly returned and their comparison values are

Gross alpha

Gross beta

${ }^{60} \mathrm{Co}$

${ }^{137} \mathrm{Cs}$

Total radioactive strontium

Tritium
$3 \mathrm{~Bq} / \mathrm{L}$

$9 \mathrm{~Bq} / \mathrm{L}$ (assuming ${ }^{90} \mathrm{Sr}$ )

$46 \mathrm{~Bq} / \mathrm{L}$

$28 \mathrm{~Bq} / \mathrm{L}$

$9 \mathrm{~Bq} / \mathrm{L}$

$18,500 \mathrm{~Bq} / \mathrm{L}$

If the analyzed water from a well meets the criteria described in the preceding paragraphs, and if the $\mathrm{pH}$ of the water in the drum at the well is between 2 and 12.5 , then the drummed water is returned to the ground near the well. If any criterion is not met, the drummed water is transported to the appropriate facility for disposal by WMO.

According to historical data, the following wells have already been determined to exceed the comparison values:

- 843, and

- 1243. 
Purge water from these wells will be managed as Category 22 or 24 according to analytical results.

\subsection{WASTE PACKAGING}

After waste has been characterized and segregated according to category, waste packets can be created. Waste is packaged by the STL according to guidance provided by the GCO. A Waste Item Description Form is filled out for each packet. One bar code label is placed on the waste packed, and the other is placed on the Waste Item Description Form associated with the specific packet. The bar code label number is then copied onto the Container Packing List. When the container is full, the GCO and the STL will complete a Waste Pickup Request Form to be submitted to WMO by the GCO. The Waste Management forms and their instructions for use, as well as the solid and liquid waste acceptance criteria, are included in the WAG 6 FOP Manual.

\subsection{WASTE TRANSPORTATION}

When waste drums become full of liquid, if there is not sufficient analytical data available to categorize the waste, the drums will be sampled. When the liquid waste can be categorized, the original drum site will be considered the temporary waste storage area and the drums will be transported by WMO. Energy Systems personnel will manage and conduct all transportation of waste to locations outside WAG 6 as well as all liquid waste transportation. 


\section{DATA MANAGEMENT}

\subsection{INTRODUCTION}

The data management team will create "Blank Form Books" filled with previously bar coded forms to be used by the field teams. Each type of form will be stored in a separate book and will have the bar code preattached to the bottom right corner of the form. A copy of the appropriate form will be inserted on the outside cover of the "Blank Form Book," and the binder will signify the form number. The form bar code label will be scanned by the STL entering it into the bar code reader for uploading to the data base when using the form. If that form is not used after being taken to the field, the STL will return the blank form to the notebook for use on another day.

The form bar code numbers must be used in sequence for record keeping purposes. The form bar code numbers will serve as identifiers for location of the forms in the files. When the STL returns to the trailer at the end of the day, the forms will be forwarded to the FTM for review. The DM will receive all completed forms and the data diskettes downloaded from the bar code reader on a daily basis. The electronic-data-downloading diskettes will be downloaded from the monitoring equipment will be forwarded to the DM by the FTM on a daily basis.

\subsection{DATA DOWNLOADING}

Field data collected during the WAG 6 Groundwater Quality Monitoring Program will be obtained manually. Some of the manual data will be entered into the WAG 6 data base using bar code equipment. However, field documentation forms will also be completed and used by the sampling team as a quality check against the data base.

Manual data generated for groundwater quality monitoring will consist of water levels, manual sample collection information, and in situ parameter measurements. These forms will be compared with the data base at a later time to ensure that all the information entered into the bar code reader was correct.

\subsection{PROCEDURES FOR COMPLETING GROUNDWATER QUALITY (GWQ) FORMS}

The WAG 6 groundwater quality sampling team will be using a bar code reader in the field to record most of the information that will be tracked in the WAG 6 project data base.

\section{GWQ-01: WAG 6-WELL PURGING AND SAMPLING FORM}

Before leaving the trailer, the STL will pull one form GWQ-01 for each monitoring location to be visited that day. Upon arrival at the site, the STL will scan the monitoring location, the sample team's badges (by role), the field logbook number, the form bar code label, and the equipment bar code ID of the HORIBA installed at that location. The reader will then prompt the STL to enter the temperature, $\mathrm{pH}$, conductivity, and dissolved oxygen field measurements. The STL will then manually enter the "Total depth of well" and "Depth to water from reference point." The reader will calculate the height of the water column. The reader will prompt the STL to enter the diameter of the well (i.e., 2 in., 4 in., or 6 in.). The reader will then display 
the calculated fields citing "Height of water column," "Water column height," "total purge gal," and "casing volume." The STL will note all calculations displayed on the reader in the appropriate fields on the GWQ-01 form. The "Purge Sampling Method" will default to pump. The reader will prompt the STL to enter "Final Purge Volume." The STL will then scan the bar code sample ID and the sample type and analytes from a menu card. The "Comments" field is optional and will not be captured by the reader. If there is anything concerning the event that the STL wants tracked in the data base, the STL will note that information in the "Comments" field of the form. The DM will manually enter the information once the form has been submitted and the field data have been added to the data base.

\subsection{PROCEDURES FOR COMPLETING SAMPLE COLLECTION FORMS}

All sampling events will be scheduled by the FTM on a WAG 6-Weekly Activity Schedule (WAS-01). The FTM will provide the DM with a copy of Form WAS-01 in order to have the WAG 6-Field Collection Task Map (FCTM-01) printed. The Field Technician will use Form FCTM-01 to assemble the sample kits and record the sample numbers used.

Once the kits are assembled, the STL will initiate the sampling event by notifying the DM to print the WAG 6-Field Activity Sheet (FAS-01). Form FAS-01 will be used in the field by the sampling team to collect all samples. Any incorrect or additional information will be noted on the form by the STL and returned to the FTM, who will review the form and forward it to the DM for update of the data base.

When the samples are ready for shipment, the STL will note on the FAS which samples are to be shipped and a WAG 6-Chain-of-Custody Form (COC-01) will be printed by the DM and signed by the Field Technician. Form COC-01 will accompany the samples to the analytical laboratory. A copy of the form will be retained in the project files. 


\section{REFERENCES}

ASME (American Society of Mechanical Engineers) 1989. Quality Assurance Program Requirements for Nuclear Facilities, ASME NQA-1. New York.

CDM Federal (CDM Federal Programs Corporation) 1993. Quality Assurance Plan for Characterization and Monitoring Activities at Waste Area Grouping 6, Oak Ridge National Laboratory, Oak Ridge, Tennessee.

DOE (U.S. Department of Energy) 1993a. Environmental Monitoring Plan for Waste Area Grouping 6 at Oak Ridge National Laboratory, Oak Ridge, Tennessee, DOE/OR/011192\&D1. Prepared by Science Applications International Corporation.

DOE (U.S. Department of Energy) 1993b. Quality Assurance Project Plan for the Environmental Monitoring Program in Waste Area Grouping 6 at Oak Ridge National Laboratory, Oak Ridge, Tennessee, DOE/OR/01-1193\&D1. Prepared by Gilbert/ Commonwealth, Inc., Oak Ridge National Laboratory, Oak Ridge, Tennessee, September.

Energy Systems (Martin Marietta Energy Systems, Inc.) 1991. Resource Conservation and Recovery Act Facility Investigation Report for Waste Area Grouping 6 at Oak Ridge National Laboratory, Oak Ridge, Tennessee, ES/ER-22/V2\&D1. Oak Ridge National Laboratory, Oak Ridge, Tennessee.

Energy Systems (Martin Marietta Energy Systems, Inc.) 1993. Environmental Restoration Quality Program Plan, ES/ER/TM-4/R3. Oak Ridge National Laboratory, Oak Ridge, Tennessee.

EPA (U.S. Environmental Protection Agency) 1983. Interim Guidelines and Specifications for Preparing Quality Assurance Project Plans, QAMS-005/80, EPA-600/4-83-004. Washington, D.C.

EPA (U.S. Environmental Protection Agency) 1991. Management of Investigation-derived Waste During Site Investigations, EPA/540/G-91/009. 
APPENDIX A

FIELD FORMS 

Monitoring Location:

STL Badge No.:

Weather:

Comments:
Field Logbook Number:

Date:

\section{Total depth of well}

Depth to water from reference point

Height of water column

Water column height

$$
2^{*}-0.16
$$

(x) $4^{*}-0.65 \mathrm{gal} / \mathrm{ft}(\Rightarrow)$ total purge gal

$$
6^{\circ}-1.47
$$

gal/casing volume ( $x$ ) 3 casing volumes (=)

Purge Method

Sampling Method

Purge water containerized?

PURGE RATE (During Well Purging)

$$
\mathbf{Y} / \mathbf{N}
$$

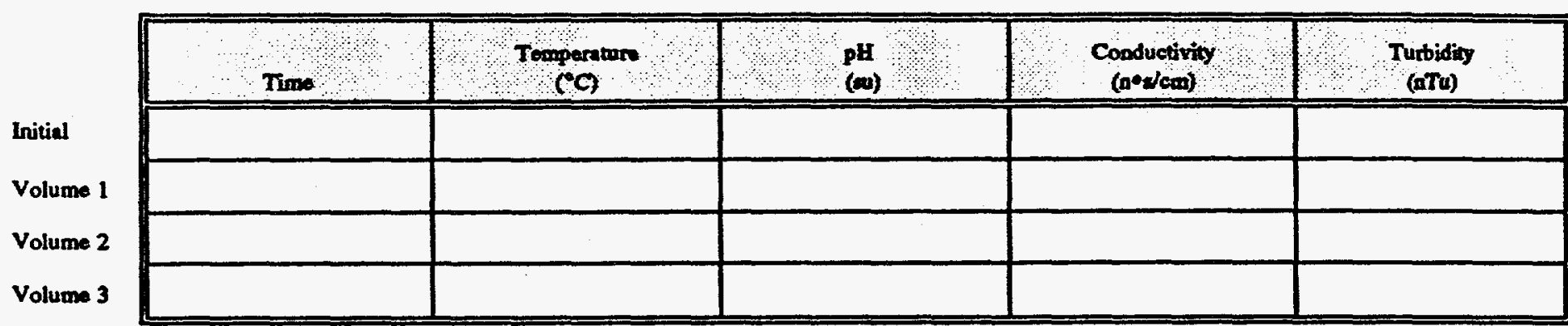

Time Sampled

HORIBA (Serial No.):

Temperature $\left({ }^{\circ} \mathrm{C}\right)$ :
Purge Rate

Time of Calibration Check:

Conductivity ( $\mu \mathrm{S} / \mathrm{cm})$ :
Procedure:

Procedure: 



\section{WAG 6 - MONTTORING VARIANCE REQUEST FORM}

(Once completed, insert this form into site notebook. If more the one site is affected, insert a cops of this form into all appropriate notebooks.)

\section{Matrix:}

ID of affected site(s):

Name and title of person making request:

Date:

Document very specifically the variance being requested. Be sure to identify all pertinent Data Quality Objectives that are affected by this variance:

Document the reasons for requesting the variance:

Document the time scale of the variance. Include dates at which this variance will start and end (if applicable):

Variance approval signature: STL:

Date:

FIM:

Date:

WAG 6 Project Manager:

Date:

Data entry signature/date:

Data verification signature/date: 



\section{WAG 6 - RECORD OF REPAIR FORM}

\section{DATE:}

EMPLOYEB BADGE NO.:

BQUIPMENT BAR CODE NO.:

EQUIPMENT STATUS: IN-USE (circle one)

AVAILABLE

Disposition of unit:
Comments:

If yes, list inspection form number or logbook number.

Nature of damage if known: Date found:

Was unit repairable in situ? Yes No

If yes, list repairs made and person making them.

Did in situ repairs include replacing any parts/accessories? Yes No

If yes, list and describe.

Was equipment sent to offsite vendor for repair? Yes No If yes, list:

Vendor: Address:

Airbill No. (if shipped):

Work Onder No:

Date Sent:

Initial:

Date returned: Received by:

Type of repair:

Was unit returned in good working condition? Yes / No

If no, please describe:

Retumed Equipment Status:

Form Bar Code Label

Sample Task Leader Signature/Date:

Data Entry Signature/Date:

Data Verification Signature/Date: 
WAG 6 - CHAIN OF CUSTODY

\begin{tabular}{|c|c|c|c|c|c|c|c|c|c|}
\hline \multicolumn{4}{|c|}{ WAG 6} & \multicolumn{4}{|c|}{ Sequential No. } & \multicolumn{2}{|r|}{ - of _ } \\
\hline \multicolumn{4}{|c|}{ Sample Task Leader } & \multicolumn{6}{|c|}{ Sumple Takk Team } \\
\hline \multirow{2}{*}{$\begin{array}{l}\text { Sample } \\
\text { Location }\end{array}$} & \multirow{2}{*}{$\begin{array}{l}\text { Sumplo } \\
\text { Date }\end{array}$} & \multirow{2}{*}{$\begin{array}{l}\text { Sample } \\
\text { Timo }\end{array}$} & \multirow{2}{*}{\begin{tabular}{|l} 
Samplo \\
Typo
\end{tabular}} & \multirow[t]{2}{*}{ Samplo } & \multicolumn{2}{|c|}{ Contsiner } & \multirow[t]{2}{*}{ Proservative } & \multirow{2}{*}{$\begin{array}{l}\text { Requested } \\
\text { Anilyaia }\end{array}$} & \multirow[t]{2}{*}{ Remarks } \\
\hline & & & & & Type & Volume & & & \\
\hline & & & & & & & & & \\
\hline & & & & & & & & & \\
\hline & & & & & & & & & \\
\hline & & & & & & & & & \\
\hline & & & & & & & & & \\
\hline & & & & & & & & & \\
\hline & & & & & & & & & \\
\hline \multicolumn{10}{|c|}{ Sample Types: RB - Rineo Blank, PB - Field Blank, TB - Trip Blank, PLD - Field Samplo, MS/MSD } \\
\hline \multicolumn{10}{|c|}{ 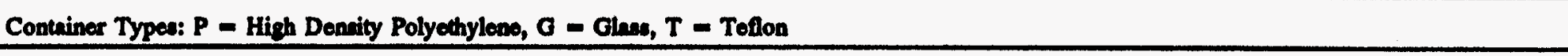 } \\
\hline \multicolumn{10}{|c|}{ Premarvative: $\mathrm{A}=\mathrm{HCl}$ to $\mathrm{pH}<2, \mathrm{~B}-\mathrm{HNO}$, to $\mathrm{pH}<2, \mathrm{C}=\mathrm{H}_{2} \mathrm{SO}_{4}$ to $\mathrm{pH}<2, \mathrm{D}-\mathrm{NaOH}$ to $\mathrm{pH}>12, \mathrm{E}=$ Other (Specify) } \\
\hline \multicolumn{3}{|c|}{ Laboratory: } & \multicolumn{4}{|c|}{ Deto Submittod to Lab: } & \multirow[t]{2}{*}{ SDG ID: } & & \\
\hline \multicolumn{2}{|c|}{ Rellinquiched by: } & Deto: & Time: & \multicolumn{3}{|c|}{ Roceived by: } & & Dete: & Time: \\
\hline \multicolumn{2}{|c|}{ Relinquishod by: } & Dute: & Time: & \multicolumn{4}{|c|}{ Received by: } & Date: & Time: \\
\hline \multicolumn{2}{|c|}{ Relinquished by: } & Date: & Timo: & \multicolumn{4}{|c|}{ Received by: } & Daco: & Time: \\
\hline \multicolumn{3}{|c|}{ Sample Disposed by: } & & \multicolumn{2}{|l|}{ Dato: } & Time: & & \multicolumn{2}{|l|}{ Airbill No.: } \\
\hline
\end{tabular}

Form Bar Code Labed 


\section{A-11}

WAG 6 - WEEKLY ACTIVITY SCHEDULE

FTM Badge No.:

Date $(\mathrm{mm} / \mathrm{dd} / \mathrm{yy})$ :

\begin{tabular}{|c|c|c|c|c|}
\hline \multicolumn{5}{|c|}{ Groundwater Quality } \\
\hline \multicolumn{5}{|c|}{ Activity Period: } \\
\hline \multirow{2}{*}{\multicolumn{2}{|c|}{ Site IDs }} & \multicolumn{3}{|c|}{ Surplus Bottles } \\
\hline & & \multirow[t]{2}{*}{ Quantity } & \multirow[t]{2}{*}{ Type } & \multirow[t]{2}{*}{ Volume } \\
\hline & & & & \\
\hline & & & & \\
\hline & & & & \\
\hline & & & & \\
\hline & & & & \\
\hline \multicolumn{5}{|c|}{ Surface Water } \\
\hline \multicolumn{5}{|c|}{ Activity Period: } \\
\hline \multirow{2}{*}{ Site IDs } & \multirow{2}{*}{$\begin{array}{c}\text { Type of } \\
\text { Sampling }\end{array}$} & \multicolumn{3}{|c|}{ Surplus Bottles } \\
\hline & & Quantity & Type & Volume \\
\hline & & & & \\
\hline & & & & \\
\hline & & & & \\
\hline & & & & \\
\hline & & & & \\
\hline \multicolumn{5}{|c|}{ Seeps and Springs } \\
\hline \multicolumn{5}{|c|}{ Activity Period: } \\
\hline \multirow{2}{*}{\multicolumn{2}{|c|}{ Site Ds }} & \multicolumn{3}{|c|}{ Surplus Bottles } \\
\hline & & Quantity & Type & Volume \\
\hline & & & & \\
\hline & & & & \\
\hline & & & & \\
\hline & & & & \\
\hline & & & & \\
\hline
\end{tabular}

FTM Signature/Date:

Data Entry Signature/Date:

Data Verification Signature/Date: 

WAG 6 - FIELD COLLECTION TASK MAP

Field Matrix:

Task:

Sampling Date:
Kit Identifier:

Kit Preparation Date:

Field Activity Sheet Number:

Field Logbook Number:

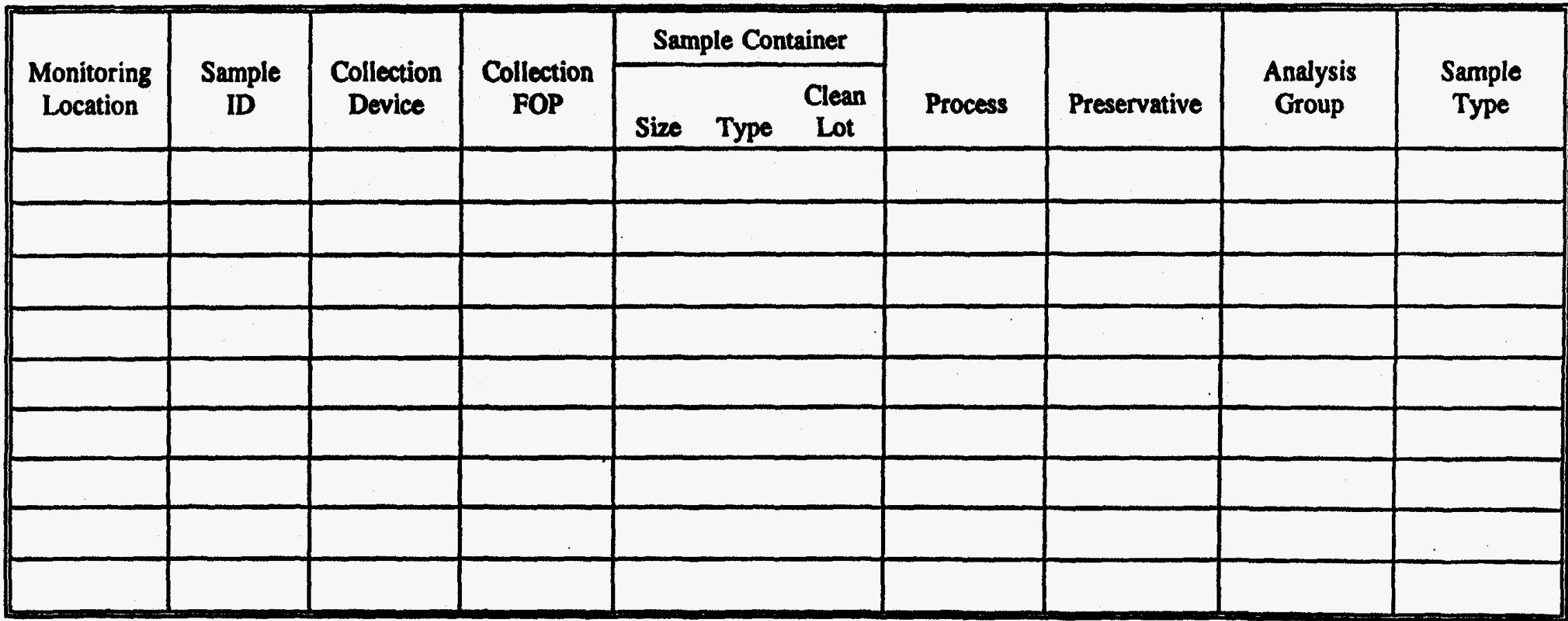

Completed By:

Date:

Form Bar Code Label 

WAG 6 - FIELD ACTTVITY SHEET

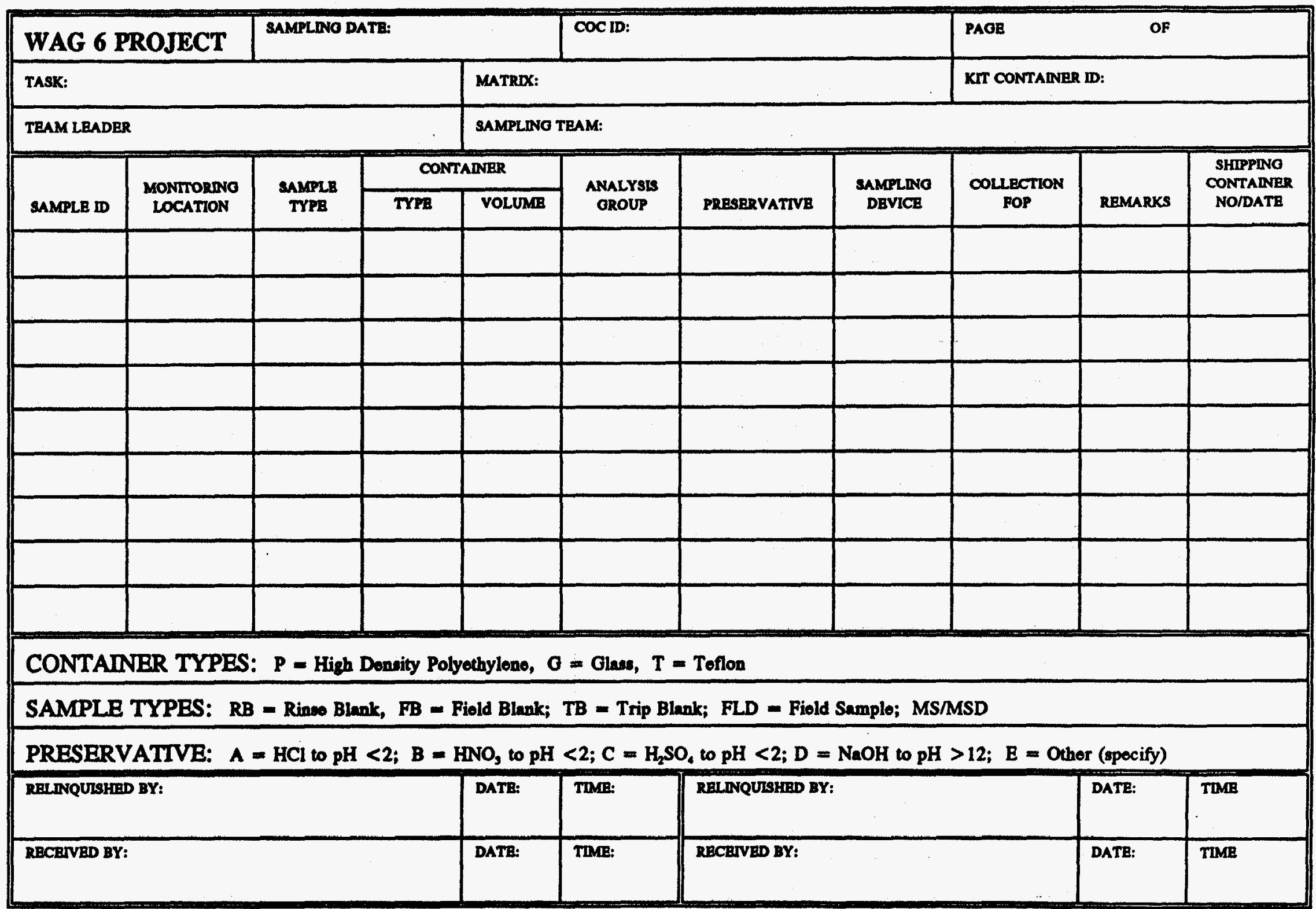

Form Bar Code Label 


\section{APPENDIX B}

SAMPLING SCHEDULES 


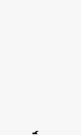


Table B.1. List of analytes, by well, for first-quarter groundwater quality monitoring at WAG 6

\begin{tabular}{|c|c|c|c|c|c|c|c|c|c|c|c|c|c|}
\hline \multicolumn{14}{|c|}{ First Quarter List of Analytes } \\
\hline Well & CLP Vols" & $\begin{array}{l}\text { CLP } \\
\text { Svols }\end{array}$ & $\begin{array}{c}\text { CLP } \\
\text { Pest/PC } \\
\text { Bs }\end{array}$ & $\begin{array}{l}\text { CLP } \\
\text { Metals }\end{array}$ & Cyanide & $\begin{array}{l}\text { Gross } \\
\text { Alpha }\end{array}$ & $\begin{array}{l}\text { Gamma } \\
\text { Scan }\end{array}$ & ${ }^{3} \mathrm{H}$ & ${ }^{\infty} \mathrm{Sr}$ & Anions & $\begin{array}{l}\text { DOC } \\
\text { DIC }\end{array}$ & Alkalinity & $\begin{array}{l}\text { Field Quality } \\
\text { Control Samples }\end{array}$ \\
\hline 648 & $\mathbf{x}$ & $\mathrm{x}$ & $\mathbf{x}$ & $\mathbf{x}$ & $\mathbf{x}$ & $\mathbf{x}$ & $\mathbf{X}$ & $\mathbf{X}$ & $\mathbf{x}$ & $\mathbf{x}$ & $\mathbf{x}$ & $\mathbf{x}$ & Trip blank ${ }^{b}$ \\
\hline 745 & $\mathbf{x}$ & $\mathbf{X}$ & $\mathbf{x}$ & $\mathbf{x}$ & $\mathbf{x}$ & $\mathbf{x}$ & $\mathbf{x}$ & $\mathbf{x}$ & $\mathbf{x}$ & $\mathbf{x}$ & $\mathbf{x}$ & $\mathbf{X}$ & Trip blank \\
\hline 831 & $\mathbf{x}$ & $\mathrm{x}$ & $\mathbf{x}$ & $\mathbf{x}$ & $\mathbf{X}$ & $\mathbf{x}$ & $\mathbf{x}$ & $\mathbf{x}$ & $\mathbf{x}$ & $\mathbf{x}$ & $\mathbf{x}$ & $\mathbf{X}$ & Trip blank \\
\hline 832 & $\mathbf{x}$ & $\mathbf{x}$ & $\mathrm{x}$ & $\mathbf{x}$ & $\mathbf{x}$ & $\mathbf{x}$ & $\mathbf{x}$ & $\mathbf{x}$ & $\mathbf{x}$ & $\mathbf{x}$ & $\mathbf{x}$ & $\mathrm{X}$ & Trip blank \\
\hline 833 & $\mathbf{x}$ & $\mathbf{x}$ & $\mathrm{x}$ & $\mathbf{x}$ & $\mathbf{x}$ & $\mathbf{x}$ & $\mathrm{x}$ & $\mathrm{x}$ & $\mathbf{x}$ & $\mathbf{x}$ & $\mathrm{x}$ & $\mathrm{X}$ & Trip blank \\
\hline 835 & $\mathbf{x}$ & $X$ & $\mathrm{x}$ & $\mathbf{x}$ & $\mathrm{X}$ & $\mathrm{x}$ & $\mathrm{x}$ & $\mathbf{X}$ & $\mathrm{X}$ & $\mathrm{x}$ & $\mathbf{x}$ & $\mathbf{X}$ & Trip blank \\
\hline 836 & $\mathbf{x}$ & $\mathbf{x}$ & $\mathrm{x}$ & $\mathbf{x}$ & $\mathbf{x}$ & $\mathbf{x}$ & $\mathbf{x}$ & $\mathbf{x}$ & $\mathbf{x}$ & $\mathbf{x}$ & $\mathbf{x}$ & $\mathbf{x}$ & Trip blank \\
\hline 837 & $\mathbf{x}$ & $x$ & $\mathbf{x}$ & $\mathbf{X}$ & $\mathbf{X}$ & $\mathrm{X}$ & $\mathrm{X}$ & $\mathrm{X}$ & $\mathrm{x}$ & $\mathrm{x}$ & $\mathbf{x}$ & $\mathbf{X}$ & Trip blank \\
\hline 838 & $\mathbf{x}$ & $\mathbf{x}$ & $\mathbf{x}$ & $\mathbf{x}$ & $\mathbf{x}$ & $\mathbf{x}$ & $\mathbf{x}$ & $\mathbf{x}$ & $\mathbf{x}$ & $\mathbf{x}$ & $\mathbf{x}$ & $\mathrm{x}$ & Trip blank \\
\hline 839 & $\mathbf{x}$ & $\mathbf{x}$ & $\mathbf{x}$ & $\mathbf{x}$ & $\mathbf{x}$ & $x$ & $\mathrm{x}$ & $\mathbf{x}$ & $\mathbf{x}$ & $\mathbf{x}$ & $\mathbf{x}$ & $\mathbf{x}$ & $\begin{array}{l}\text { Trip blank } \\
\text { Duplicater }\end{array}$ \\
\hline 840 & $\mathrm{x}$ & $\mathrm{X}$ & $\mathrm{X}$ & $\mathrm{X}$ & $\mathrm{X}$ & $\mathbf{X}$ & $\mathrm{x}$ & $\mathrm{X}$ & $\mathrm{x}$ & $\mathrm{x}$ & $x$ & $X$ & Trip blank \\
\hline 841 & $\mathrm{x}$ & $X$ & $\mathrm{X}$ & $X$ & $X$ & $x$ & $\mathrm{x}$ & $\mathrm{X}$ & $\mathbf{x}$ & $\mathrm{x}$ & $\mathrm{X}$ & $\mathrm{X}$ & Trip blank \\
\hline 842 & $\mathrm{x}$ & $\mathrm{X}$ & $\mathbf{X}$ & $\mathbf{x}$ & $\mathbf{x}$ & $x$ & $\mathrm{x}$ & $\mathrm{x}$ & $\mathbf{X}$ & $\mathbf{x}$ & $\mathrm{X}$ & $\mathrm{X}$ & Trip blank \\
\hline 843 & $\mathrm{x}$ & $X$ & $\mathrm{X}$ & $\mathrm{X}$ & $\mathrm{X}$ & $\mathbf{X}$ & $\mathrm{X}$ & $\mathbf{X}$ & $\mathrm{X}$ & $x$ & $\mathrm{X}$ & $\mathrm{X}$ & Trip blank \\
\hline 844 & $\mathrm{x}$ & $\mathrm{x}$ & $\mathbf{x}$ & $\mathbf{x}$ & $\mathbf{x}$ & $\mathbf{x}$ & $x$ & $\mathbf{X}$ & $\mathbf{x}$ & $\mathbf{x}$ & $\mathbf{x}$ & $\mathrm{X}$ & Trip blank \\
\hline 845 & $\mathrm{x}$ & $\mathbf{x}$ & $\mathbf{x}$ & $\mathbf{x}$ & $\mathrm{x}$ & $x$ & $\mathbf{x}$ & $\mathrm{x}$ & $\mathbf{x}$ & $\mathbf{x}$ & $\mathrm{x}$ & $\mathbf{x}$ & Trip blank \\
\hline 846 & $x$ & $\mathbf{x}$ & $\mathbf{x}$ & $\mathbf{x}$ & $\mathbf{x}$ & $\mathbf{x}$ & $\mathbf{x}$ & $\mathrm{x}$ & $\mathbf{x}$ & $\mathbf{x}$ & $\mathbf{x}$ & $\mathbf{x}$ & Trip blank \\
\hline 847 & $\mathrm{x}$ & $\mathbf{x}$ & $\mathbf{x}$ & $\mathrm{x}$ & $\mathbf{x}$ & $x$ & $\mathbf{x}$ & $\mathbf{x}$ & $\mathbf{x}$ & $\mathbf{x}$ & $\mathbf{x}$ & $\mathrm{x}$ & Trip blank \\
\hline
\end{tabular}


Table B.1 (continued)

\begin{tabular}{|c|c|c|c|c|c|c|c|c|c|c|c|c|c|}
\hline \multicolumn{14}{|c|}{ First Quarter List of Analytes } \\
\hline Well & CLP Vols" & $\begin{array}{l}\text { CLP } \\
\text { Svols }\end{array}$ & $\begin{array}{c}\text { CLP } \\
\text { Pest } / \text { PC } \\
\text { Bs }\end{array}$ & $\begin{array}{l}\text { CLP } \\
\text { Metals }\end{array}$ & Cyanide & $\begin{array}{l}\text { Gross } \\
\text { Alpha }\end{array}$ & $\begin{array}{l}\text { Gamma } \\
\text { Scan }\end{array}$ & ${ }^{3} \mathbf{H}$ & $\mathrm{s}_{\mathrm{Sr}}$ & Anions & $\begin{array}{l}\text { DOC } \\
\text { DIC }\end{array}$ & Alkalinity & $\begin{array}{l}\text { Field Quality } \\
\text { Control Samples }\end{array}$ \\
\hline 848 & $\mathbf{x}$ & $\mathbf{x}$ & $\mathbf{x}$ & $\mathbf{x}$ & $\mathbf{X}$ & $\mathrm{X}$ & $\mathbf{x}$ & $\mathbf{X}$ & $\mathbf{x}$ & $\mathbf{x}$ & $\mathbf{x}$ & $\mathbf{x}$ & Trip blank \\
\hline 849 & $\mathbf{x}$ & $\mathbf{x}$ & $\mathbf{x}$ & $\mathbf{x}$ & $\mathbf{x}$ & $\mathbf{x}$ & $\mathbf{x}$ & $\mathbf{x}$ & $\mathbf{x}$ & $\mathbf{x}$ & $\mathbf{x}$ & $\mathbf{x}$ & $\begin{array}{l}\text { Trip blank } \\
\text { Spike(s) } \\
\text { Duplicates }^{c}\end{array}$ \\
\hline 850 & $\mathbf{x}$ & $\mathbf{x}$ & $\mathbf{X}$ & $\mathbf{x}$ & $\mathbf{X}$ & $\mathbf{X}$ & $\mathbf{x}$ & $\mathbf{x}$ & $\mathbf{x}$ & $\mathbf{x}$ & $\mathbf{X}$ & $\mathbf{x}$ & Trip blank \\
\hline 851 & $\mathbf{X}$ & $\mathbf{X}$ & $\mathbf{X}$ & $\mathbf{X}$ & $\mathbf{x}$ & $\mathbf{x}$ & $\mathbf{X}$ & $\mathbf{x}$ & $\mathbf{x}$ & $\mathbf{x}$ & $\mathbf{x}$ & $\mathbf{x}$ & Trip blank \\
\hline 852 & $\mathbf{X}$ & $\mathbf{x}$ & $\mathbf{x}$ & $\mathbf{X}$ & $\mathbf{x}$ & $\mathbf{X}$ & $\mathbf{x}$ & $\mathbf{X}$ & $\mathbf{X}$ & $\mathbf{x}$ & $\mathrm{X}$ & $\mathrm{x}$ & Trip blank \\
\hline 854 & $\mathbf{X}$ & $X$ & $\mathbf{X}$ & $\mathbf{X}$ & $\mathbf{X}$ & $\mathrm{X}$ & $\mathbf{X}$ & $\mathrm{x}$ & $\mathbf{X}$ & $\mathrm{X}$ & $\mathbf{X}$ & $\mathrm{X}$ & Trip blank \\
\hline 855 & $\mathbf{x}$ & $\mathbf{X}$ & $\mathrm{x}$ & $\mathbf{X}$ & $\mathrm{X}$ & $\mathbf{X}$ & $\mathrm{x}$ & $\mathbf{X}$ & $\mathbf{x}$ & $\mathbf{X}$ & $\mathrm{X}$ & $\mathrm{x}$ & Trip blank \\
\hline 856 & $\mathbf{X}$ & $\mathbf{X}$ & $\mathbf{X}$ & $\mathbf{x}$ & $\mathbf{x}$ & $\mathbf{x}$ & $\mathrm{x}$ & $\mathbf{x}$ & $\mathbf{X}$ & $\mathrm{x}$ & $\mathbf{x}$ & $\mathbf{X}$ & Trip blank \\
\hline 857 & $\mathbf{X}$ & $\mathbf{X}$ & $\mathbf{X}$ & $\mathbf{X}$ & $\mathbf{X}$ & $\mathbf{X}$ & $\mathrm{X}$ & $\mathrm{X}$ & $\mathbf{x}$ & $X$ & $\mathrm{x}$ & $\mathrm{X}$ & Trip blank \\
\hline 858 & $\mathbf{x}$ & $x$ & $\mathbf{x}$ & $\mathbf{x}$ & $\mathbf{x}$ & $\mathbf{x}$ & $\mathbf{x}$ & $\mathbf{x}$ & $\mathbf{x}$ & $\mathrm{x}$ & $\mathbf{x}$ & $\mathbf{x}$ & Trip blank \\
\hline 859 & $\mathrm{X}$ & $\mathbf{X}$ & $\mathbf{x}$ & $x$ & $\mathbf{X}$ & $\mathrm{x}$ & $\mathrm{x}$ & $\mathrm{X}$ & $\mathbf{x}$ & $\mathbf{x}$ & $\mathrm{x}$ & $\mathrm{x}$ & Trip blank \\
\hline 860 & $\mathbf{X}$ & $\mathbf{x}$ & $\mathbf{x}$ & $\mathbf{X}$ & $\mathbf{x}$ & $\mathbf{x}$ & $\mathrm{x}$ & $\mathbf{x}$ & $\mathbf{x}$ & $\mathbf{x}$ & $\mathbf{X}$ & $\mathbf{x}$ & $\begin{array}{l}\text { Trip blank } \\
\text { Duplicate }^{c}\end{array}$ \\
\hline 1036 & $\mathrm{X}$ & $\mathbf{X}$ & $\mathbf{X}$ & $\mathbf{X}$ & $\mathbf{x}$ & $\mathbf{x}$ & $\mathrm{x}$ & $\mathrm{X}$ & $\mathbf{x}$ & $\mathrm{X}$ & $\mathrm{x}$ & $\mathrm{X}$ & Trip blank \\
\hline 1039 & $\mathrm{x}$ & $\mathrm{X}$ & $\mathbf{X}$ & $\mathrm{x}$ & $\mathrm{x}$ & $\mathbf{x}$ & $x$ & $\mathrm{X}$ & $\mathrm{X}$ & $\mathbf{x}$ & $\mathrm{x}$ & $\mathbf{x}$ & Trip blank \\
\hline 1166 & $\mathrm{X}$ & $X$ & $X$ & $x$ & $\mathrm{X}$ & $X$ & $\mathrm{x}$ & $\mathbf{X}$ & $\mathbf{X}$ & $\mathbf{X}$ & $\mathrm{X}$ & $\mathrm{X}$ & Trip blank \\
\hline 1225 & $\mathbf{X}$ & $\mathbf{x}$ & $\mathbf{X}$ & $\mathbf{X}$ & $\mathbf{X}$ & $\mathbf{x}$ & $\mathbf{x}$ & $\mathrm{X}$ & $\mathbf{x}$ & $\mathrm{x}$ & $\mathbf{X}$ & $\mathbf{x}$ & Trip blank \\
\hline 1233 & $\mathbf{X}$ & $\mathbf{x}$ & $\mathbf{x}$ & $\mathbf{X}$ & $\mathrm{X}$ & $\mathbf{x}$ & $\mathrm{x}$ & $\mathrm{x}$ & $\mathbf{x}$ & $\mathrm{X}$ & $\mathrm{X}$ & $\mathrm{X}$ & Trip blank \\
\hline
\end{tabular}


Table B.1 (continued)

\begin{tabular}{|c|c|c|c|c|c|c|c|c|c|c|c|c|c|}
\hline \multicolumn{14}{|c|}{ First Quarter List of Analytes } \\
\hline Well & CLP Vols" & $\begin{array}{l}\text { CLP } \\
\text { Svols }\end{array}$ & $\begin{array}{c}\text { CLP } \\
\text { Pest/PC } \\
\text { Bs } \\
\end{array}$ & $\begin{array}{l}\text { CLP } \\
\text { Metals }\end{array}$ & Cyanide & $\begin{array}{l}\text { Gross } \\
\text { Alpha }\end{array}$ & $\begin{array}{l}\text { Gamma } \\
\text { Scan }\end{array}$ & ${ }^{3} \mathrm{H}$ & ${ }^{20} \mathrm{Sr}$ & Anions & $\begin{array}{l}\text { DOC } \\
\text { DIC }\end{array}$ & Alkalinity & $\begin{array}{l}\text { Field Quality } \\
\text { Control Samples }\end{array}$ \\
\hline 1237 & $\mathbf{X}$ & $\mathrm{x}$ & $\mathbf{x}$ & $\mathbf{x}$ & $\mathbf{x}$ & $\mathbf{x}$ & $\mathbf{x}$ & $\mathbf{X}$ & $\mathbf{x}$ & $\mathbf{x}$ & $\mathbf{x}$ & $\mathbf{x}$ & Trip blank \\
\hline 1241 & $\mathbf{x}$ & $\mathbf{x}$ & $x$ & $\mathbf{x}$ & $\mathbf{x}$ & $\mathbf{x}$ & $\mathbf{x}$ & $\mathbf{x}$ & $\mathbf{x}$ & $\mathrm{x}$ & $\mathbf{x}$ & $\mathbf{X}$ & Trip blank \\
\hline 1242 & $\mathbf{x}$ & $\mathbf{x}$ & $\mathbf{X}$ & $\mathbf{x}$ & $\mathbf{x}$ & $\mathbf{x}$ & $\mathbf{x}$ & $\mathbf{x}$ & $\mathbf{x}$ & $\mathbf{x}$ & $\mathrm{x}$ & $\mathrm{X}$ & Trip blank \\
\hline 1243 & $\mathrm{X}$ & $\mathbf{x}$ & $\mathbf{x}$ & $\mathbf{X}$ & $\mathbf{X}$ & $\mathbf{x}$ & $\mathrm{X}$ & $x$ & $\mathrm{x}$ & $\mathbf{X}$ & $\mathbf{x}$ & $\mathbf{X}$ & Trip blank \\
\hline NWQ-1 & $\mathbf{x}$ & $\mathbf{x}$ & $\mathbf{x}$ & $\mathbf{x}$ & $\mathbf{x}$ & $\mathbf{x}$ & $\mathbf{x}$ & $\mathbf{x}$ & $\mathrm{x}$ & $\mathbf{x}$ & $\mathbf{x}$ & $\mathbf{x}$ & $\begin{array}{c}\text { Trip blank } \\
\text { Spike(s) } \\
\text { Duplicate }^{\text {d }}\end{array}$ \\
\hline NWQ-2 & $x$ & $\mathrm{x}$ & $\mathrm{X}$ & $\mathrm{X}$ & $\mathbf{X}$ & $\mathbf{X}$ & $\mathbf{X}$ & $\mathbf{x}$ & $\mathbf{x}$ & $\mathrm{X}$ & $\mathrm{X}$ & $\mathrm{X}$ & Trip blank \\
\hline NWQ-3 & $\mathbf{X}$ & $\mathbf{x}$ & $\mathbf{X}$ & $\mathbf{X}$ & $\mathbf{x}$ & $\mathbf{x}$ & $\mathrm{X}$ & $x$ & $\mathrm{x}$ & $\mathrm{x}$ & $\mathrm{X}$ & $\mathrm{X}$ & Trip blank \\
\hline NWQ-4 & $\mathbf{X}$ & $\mathbf{x}$ & $\mathbf{X}$ & $\mathbf{x}$ & $\mathbf{X}$ & $\mathbf{x}$ & $\mathbf{x}$ & $\mathbf{x}$ & $\mathbf{x}$ & $\mathbf{x}$ & $\mathbf{x}$ & $x$ & Trip blank \\
\hline NWQ-5 & $\mathbf{x}$ & $\mathbf{x}$ & $\mathbf{x}$ & $\mathbf{x}$ & $\mathbf{x}$ & $\mathbf{X}$ & $\mathrm{x}$ & $\mathbf{X}$ & $\mathbf{x}$ & $\mathrm{X}$ & $\mathbf{x}$ & $\mathbf{x}$ & Trip blank \\
\hline NWQ-6 & $\mathbf{x}$ & $\mathbf{x}$ & $\mathbf{x}$ & $\mathbf{x}$ & $\mathbf{x}$ & $\mathbf{x}$ & $\mathbf{x}$ & $\mathbf{x}$ & $\mathbf{x}$ & $\mathbf{x}$ & $\mathbf{X}$ & $\mathbf{X}$ & $\begin{array}{l}\text { Trip blank } \\
\text { Duplicate }^{2}\end{array}$ \\
\hline
\end{tabular}

aCLP volatiles include RCRA volatiles.

${ }^{b}$ First quarter trip blanks will be analyzed for Contract Laboratory Program (CLP) volatiles only.

'Duplicate samples will be analyzed for the same constituents for which the original sample is analyzed.

${ }^{d}$ Spike samples will be used by the laboratory as a duplicate/spike combination for inorganics and a spike/spike duplicate combination for organics. 
Table B.2. List of analytes, by well, for second quarter groundwater quality monitoring at WAG 6

\begin{tabular}{|c|c|c|c|c|c|c|c|c|c|c|c|c|}
\hline \multicolumn{13}{|c|}{ Second Quarter List of Analytes } \\
\hline Well & CLP Vols" & CLP Svols & $\begin{array}{c}\text { CLP } \\
\text { PestPCBs } \\
\end{array}$ & $\begin{array}{l}\text { CLP } \\
\text { Metals } \\
\end{array}$ & $\begin{array}{l}\text { Gross } \\
\text { Alpha }\end{array}$ & $\begin{array}{c}\text { Gamma } \\
\text { Scan } \\
\end{array}$ & ${ }^{3} \mathrm{H}$ & $\mathrm{sSr}_{\mathrm{r}}$ & Anions & $\begin{array}{l}\text { DOC } \\
\text { DIC } \\
\end{array}$ & Alkalinity & $\begin{array}{c}\text { Field Quality } \\
\text { Control Samples }\end{array}$ \\
\hline 648 & $\mathbf{x}$ & & & $\mathrm{x}$ & $\mathrm{x}$ & $\mathbf{x}$ & $\mathrm{x}$ & $\mathbf{x}$ & & & & Trip blank ${ }^{b}$ \\
\hline 745 & $\mathbf{x}$ & & & $\mathbf{x}$ & $\mathrm{x}$ & $\mathrm{x}$ & $\mathbf{x}$ & $\mathrm{x}$ & & & & Trip blank \\
\hline 831 & $\mathrm{x}$ & & & $\mathbf{x}$ & $\mathbf{x}$ & $\mathbf{x}$ & $\mathbf{x}$ & $\mathbf{x}$ & & & & Trip blank \\
\hline 832 & $\mathbf{x}$ & & & $\mathrm{x}$ & $\mathrm{x}$ & $\mathrm{x}$ & $\mathrm{x}$ & $\mathbf{x}$ & & & & Trip blank \\
\hline 833 & $\mathrm{x}$ & & & $\mathrm{x}$ & $\mathrm{x}$ & $\mathrm{x}$ & $\mathrm{x}$ & $\mathrm{x}$ & & & & Trip blank \\
\hline 835 & $\mathbf{x}$ & & & $x$ & $\mathbf{x}$ & $\mathbf{x}$ & $\mathbf{x}$ & $\mathbf{x}$ & & & & Trip blank \\
\hline 836 & $\mathrm{x}$ & & & $\mathbf{x}$ & $\mathrm{x}$ & $\mathrm{x}$ & $\mathrm{x}$ & $\mathrm{x}$ & & & & Trip blank \\
\hline 837 & $\mathbf{x}$ & & & $\mathbf{x}$ & $\mathbf{x}$ & $\mathrm{x}$ & $\mathrm{x}$ & $\mathbf{x}$ & & & & Trip blank \\
\hline 838 & $\mathrm{x}$ & & & $\mathbf{x}$ & $\mathbf{x}$ & $\mathrm{x}$ & $\mathrm{x}$ & $x$ & & & & Trip blank \\
\hline 839 & $\mathbf{x}$ & & & $\mathbf{x}$ & $\mathbf{x}$ & $\mathrm{x}$ & $\mathrm{X}$ & $\mathbf{x}$ & & & & Trip blank \\
\hline 840 & $\mathrm{x}$ & & & $\mathbf{x}$ & $\mathbf{x}$ & $\mathrm{x}$ & $\mathrm{x}$ & $\mathrm{x}$ & & & & Trip blank \\
\hline 841 & $\mathbf{x}$ & & & $\mathbf{x}$ & $\mathbf{x}$ & $\mathrm{x}$ & $\mathbf{x}$ & $\mathbf{x}$ & & & & Trip blank \\
\hline 842 & $\mathrm{x}$ & & & $\mathbf{x}$ & $x$ & $\mathrm{x}$ & $x$ & $x$ & & & & Trip blank \\
\hline 843 & $\mathbf{x}$ & & & $\mathbf{x}$ & $\mathbf{x}$ & $\mathrm{x}$ & $\mathbf{x}$ & $\mathrm{x}$ & & & & Trip blank \\
\hline 844 & $\mathrm{x}$ & & & $\mathrm{x}$ & $\mathrm{x}$ & $\mathrm{x}$ & $x$ & $\mathrm{x}$ & & & & Trip blank \\
\hline 845 & $\mathrm{x}$ & & & $\mathbf{x}$ & $\mathrm{x}$ & $\mathbf{x}$ & $\mathbf{x}$ & $\mathrm{x}$ & & & & $\begin{array}{l}\text { Trip blank } \\
\text { Duplicate }^{c}\end{array}$ \\
\hline 846 & $\mathbf{x}$ & & & $\mathrm{x}$ & $\mathrm{x}$ & $\mathrm{x}$ & $\mathrm{x}$ & $x$ & & & & Trip blank \\
\hline 847 & $\mathbf{x}$ & & & $\mathrm{x}$ & $\mathrm{x}$ & $\mathbf{x}$ & $\mathrm{x}$ & $\mathbf{x}$ & & & & Trip blank \\
\hline
\end{tabular}




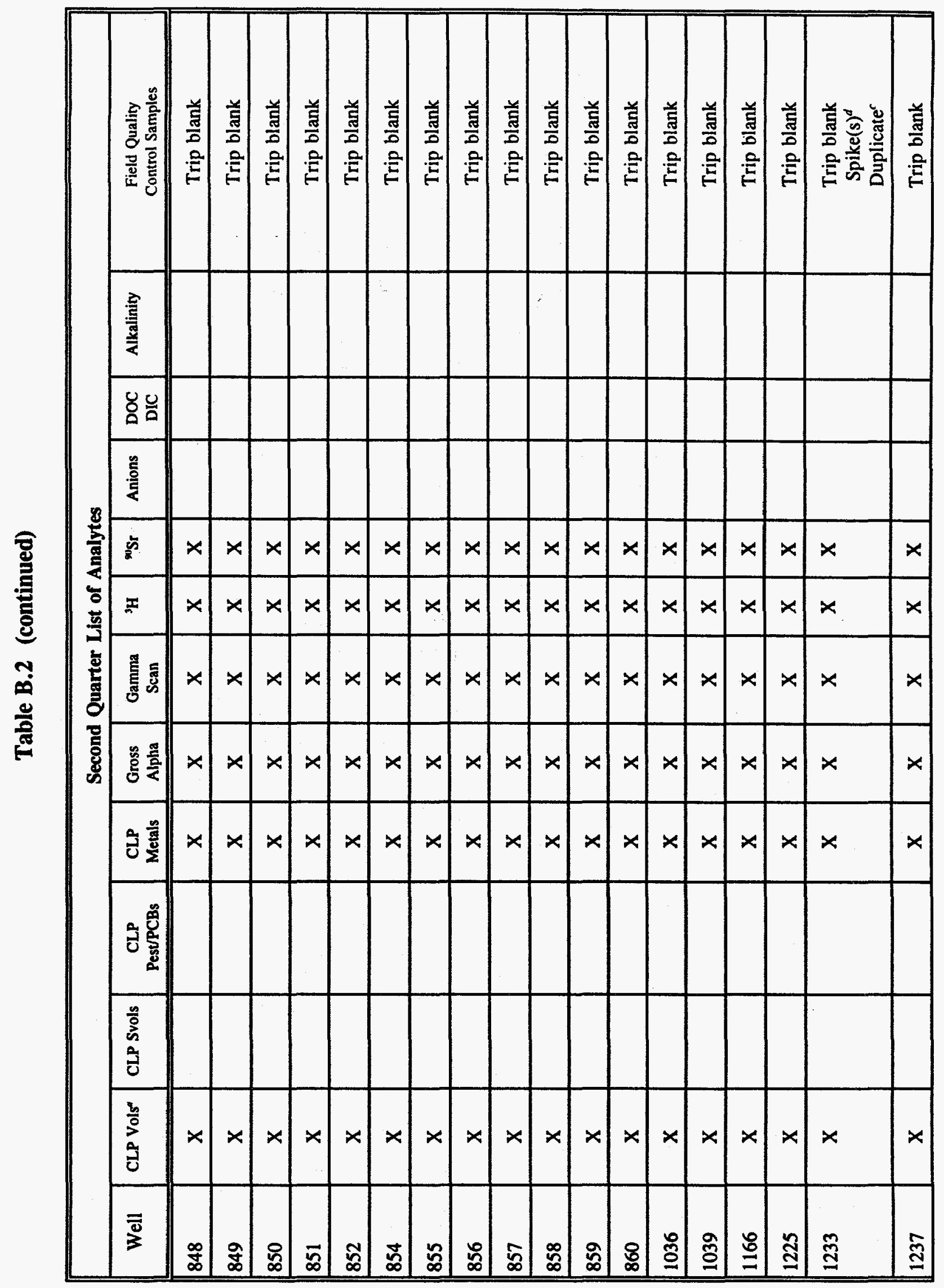


Table B.2 (continued)

\begin{tabular}{|c|c|c|c|c|c|c|c|c|c|c|c|c|}
\hline \multicolumn{13}{|c|}{ Second Quarter List of Analytes } \\
\hline Well & CLP Vols" & CLP Svols & $\begin{array}{c}\text { CLP } \\
\text { PesU/PCBs }\end{array}$ & $\begin{array}{c}\text { CLP } \\
\text { Metals }\end{array}$ & $\begin{array}{l}\text { Gross } \\
\text { Alpha }\end{array}$ & $\begin{array}{l}\text { Gamma } \\
\text { Scan }\end{array}$ & ${ }^{3} \mathbf{H}$ & ${ }^{\infty} \mathrm{Sr}$ & Anions & $\begin{array}{l}\text { DOC } \\
\text { DIC }\end{array}$ & Alkalinity & $\begin{array}{l}\text { Field Quality } \\
\text { Control Samples }\end{array}$ \\
\hline 1241 & $\mathbf{X}$ & & & $\mathbf{x}$ & $\mathbf{x}$ & $\mathbf{x}$ & $\mathbf{x}$ & $\mathbf{x}$ & & & & Trip blank \\
\hline 1242 & $\mathbf{x}$ & & & $\mathbf{x}$ & $\mathbf{x}$ & $\mathrm{X}$ & $\mathbf{X}$ & $\mathbf{x}$ & & & & Trip blank \\
\hline 1243 & $\mathbf{X}$ & & & $\mathbf{X}$ & $\mathbf{x}$ & $\mathbf{x}$ & $\mathbf{x}$ & $\mathbf{x}$ & & & & Trip blank \\
\hline NWQ-1 & $\mathbf{x}$ & & & $\mathbf{x}$ & $\mathbf{x}$ & $\mathbf{x}$ & $\mathrm{x}$ & $\mathbf{x}$ & & & & Trip blank \\
\hline NWQ-2 & $\mathbf{X}$ & & & $\mathbf{x}$ & $\mathbf{x}$ & $\mathbf{X}$ & $\mathbf{x}$ & $\mathbf{x}$ & & & & Trip blank \\
\hline NWQ-3 & $\mathbf{x}$ & & & $\mathbf{x}$ & $\mathbf{x}$ & $x$ & $\mathbf{x}$ & $\mathbf{x}$ & & & & Trip blank \\
\hline NWQ-4 & $\mathbf{x}$ & & & $\mathbf{x}$ & $\mathbf{x}$ & $\mathbf{x}$ & $\mathbf{X}$ & $\mathrm{x}$ & & & & Trip blank \\
\hline NWQ-5 & $\mathbf{x}$ & & & $\mathrm{x}$ & $\mathrm{X}$ & $\mathrm{x}$ & $\mathbf{X}$ & $\mathbf{x}$ & & & & $\begin{array}{l}\text { Trip blank } \\
\text { Duplicate }^{c}\end{array}$ \\
\hline NWQ-6 & $\mathbf{X}$ & & & $\mathbf{X}$ & $\mathbf{X}$ & $\mathbf{x}$ & $\mathbf{X}$ & $\mathbf{x}$ & & & & Trip blank \\
\hline
\end{tabular}

${ }^{a}$ CLP volatiles include RCRA volatiles.

'Second quarter trip blanks will be analyzed for CLP volatiles only.

'Duplicate samples will be analyzed for the same constituents for which the original sample is analyzed.

${ }^{d S p i k e ~ s a m p l e s ~ w i l l ~ b e ~ u s e d ~ b y ~ t h e ~ l a b o r a t o r y ~ a s ~ a ~ d u p l i c a t e / s p i k e ~ c o m b i n a t i o n ~ f o r ~ i n o r g a n i c s ~ a n d ~ a s ~ a ~ s p i k e / s p i k e ~ d u p l i c a t e ~ c o m b i n a t i o n ~ f o r ~ o r g a n i c s . ~}$ 
Table B.3. List of analytes, by well, for third-quarter groundwater quality monitoring at WAG 6

\begin{tabular}{|c|c|c|c|c|c|c|c|c|c|c|c|}
\hline \multicolumn{12}{|c|}{ Third Quarter List of Analytes } \\
\hline Well & $\begin{array}{l}\text { CLP' } \\
\text { Vols }\end{array}$ & $\begin{array}{l}\text { CLP } \\
\text { Svols }\end{array}$ & $\begin{array}{c}\text { CLP } \\
\text { Pest/PCBs }\end{array}$ & $\begin{array}{l}\text { CLP } \\
\text { Metals }\end{array}$ & $\begin{array}{l}\text { Gross } \\
\text { Alpha }\end{array}$ & $\begin{array}{l}\text { Gamma } \\
\text { Scan }\end{array}$ & ${ }^{3} \mathbf{H}$ & ${ }^{90} \mathrm{Sr}$ & $\begin{array}{l}\text { ICP Metals } \\
\text { (Filtered) }\end{array}$ & Herbicides & Field Quality Control Samples \\
\hline 648 & $\mathbf{x}$ & & & $\mathbf{x}$ & $\mathbf{x}$ & $\mathbf{x}$ & $\mathbf{x}$ & $\mathbf{x}$ & $\mathbf{x}$ & $\mathbf{x}$ & Trip blank ${ }^{b}$ \\
\hline 745 & $\mathbf{x}$ & & & $\mathbf{x}$ & $\mathbf{x}$ & $\mathbf{x}$ & $\mathbf{x}$ & $\mathbf{x}$ & $\mathbf{X}$ & $\mathbf{x}$ & Trip blank \\
\hline 831 & $\mathbf{x}$ & & & $\mathbf{x}$ & $\mathbf{x}$ & $\mathbf{x}$ & $\mathbf{X}$ & $\mathbf{x}$ & $\mathbf{x}$ & $\mathbf{x}$ & Trip blank \\
\hline 832 & $\mathbf{x}$ & & & $\mathbf{x}$ & $\mathbf{x}$ & $\mathbf{x}$ & $\mathbf{x}$ & $\mathbf{x}$ & $\mathbf{X}$ & $\mathbf{x}$ & Trip blank \\
\hline 833 & $\mathbf{x}$ & & & $\mathbf{x}$ & $\mathbf{x}$ & $\mathbf{x}$ & $\mathbf{x}$ & $\mathbf{x}$ & $\mathbf{x}$ & $\mathbf{x}$ & Trip blank \\
\hline 835 & $\mathbf{x}$ & & & $\mathbf{x}$ & $\mathbf{x}$ & $\mathbf{x}$ & $\mathbf{x}$ & $\mathbf{x}$ & $\mathbf{x}$ & $\mathbf{x}$ & Trip blank \\
\hline 836 & $\mathbf{x}$ & & & $\mathbf{x}$ & $x$ & $\mathbf{x}$ & $\mathbf{X}$ & $\mathbf{x}$ & $X$ & $\mathbf{x}$ & Trip blank \\
\hline 837 & $\mathbf{X}$ & & & $\mathbf{X}$ & $\mathbf{X}$ & $\mathrm{X}$ & $\mathrm{X}$ & $\mathbf{x}$ & $\mathrm{X}$ & $\mathbf{x}$ & Trip blank \\
\hline 838 & $\mathbf{X}$ & & & $\mathbf{x}$ & $\mathrm{x}$ & $\mathbf{x}$ & $\mathbf{x}$ & $\mathrm{X}$ & $\mathrm{X}$ & $\mathrm{x}$ & Trip blank \\
\hline 839 & $\mathbf{X}$ & & & $\mathbf{x}$ & $\mathbf{X}$ & $\mathrm{x}$ & $\mathbf{X}$ & $\mathbf{X}$ & $X$ & $\mathbf{x}$ & $\begin{array}{l}\text { Trip blank } \\
\text { Duplicate }^{c}\end{array}$ \\
\hline 840 & $\mathbf{X}$ & & & $\mathbf{x}$ & $\mathbf{x}$ & $\mathrm{X}$ & $\mathrm{X}$ & $\mathbf{X}$ & $\mathbf{X}$ & $\mathbf{X}$ & Trip blank \\
\hline 841 & $\mathbf{X}$ & & & $\mathbf{x}$ & $\mathbf{X}$ & $\mathbf{x}$ & $\mathbf{X}$ & $\mathbf{x}$ & $\mathbf{X}$ & $\mathbf{x}$ & $\begin{array}{l}\text { Trip blank } \\
\text { Duplicate }^{c}\end{array}$ \\
\hline 842 & $\mathbf{X}$ & & & $\mathbf{X}$ & $\mathbf{X}$ & $\mathbf{x}$ & $\mathbf{X}$ & $\mathbf{x}$ & $\mathrm{X}$ & $\mathrm{X}$ & Trip blank \\
\hline 843 & $\mathbf{X}$ & & & $\mathrm{X}$ & $x$ & $\mathbf{x}$ & $\mathbf{X}$ & $\mathbf{x}$ & $x$ & $\mathbf{X}$ & Trip blank \\
\hline 844 & $\mathbf{x}$ & & & $\mathbf{x}$ & $\mathrm{x}$ & $\mathrm{X}$ & $\mathrm{X}$ & $\mathrm{X}$ & $x$ & $X$ & Trip blank \\
\hline 845 & $\mathbf{X}$ & & & $\mathbf{x}$ & $\mathbf{x}$ & $\mathrm{X}$ & $\mathrm{X}$ & $\mathrm{X}$ & $\mathrm{x}$ & $\mathbf{X}$ & Trip blank \\
\hline 846 & $\mathbf{x}$ & & & $\mathbf{x}$ & $\mathbf{x}$ & $\mathbf{x}$ & $\mathrm{X}$ & $\mathrm{x}$ & $\mathbf{X}$ & $\mathbf{x}$ & Trip blank \\
\hline 847 & $\mathbf{X}$ & & & $\mathbf{X}$ & $\mathrm{x}$ & $\mathrm{x}$ & $\mathrm{X}$ & $\mathbf{X}$ & $\mathrm{X}$ & $\mathbf{X}$ & Trip blank \\
\hline 848 & $\mathbf{X}$ & & & $\mathbf{x}$ & $\mathbf{x}$ & $\mathbf{x}$ & $\mathbf{X}$ & $\mathbf{x}$ & $\mathbf{X}$ & $\mathbf{x}$ & Trip blank \\
\hline
\end{tabular}


Table B.3 (continued)

\begin{tabular}{|c|c|c|c|c|c|c|c|c|c|c|c|}
\hline \multicolumn{12}{|c|}{ Third Quarter List of Analytes } \\
\hline Well & $\begin{array}{l}\text { CLPa } \\
\text { Vols }\end{array}$ & $\begin{array}{l}\text { CLP } \\
\text { Svols }\end{array}$ & $\begin{array}{c}\text { CLP } \\
\text { Pest/PCBs } \\
\end{array}$ & $\begin{array}{l}\text { CLP } \\
\text { Metals }\end{array}$ & $\begin{array}{l}\text { Gross } \\
\text { Alpha }\end{array}$ & $\begin{array}{c}\text { Gamma } \\
\text { Scan }\end{array}$ & ${ }^{3} \mathbf{H}$ & ${ }^{*} \mathrm{Sr}$ & $\begin{array}{l}\text { ICP Metals } \\
\text { (Filtered) }\end{array}$ & Herbicides & Field Quality Control Samples \\
\hline 849 & $\mathbf{x}$ & & & $\mathbf{x}$ & $x$ & $x$ & $\mathbf{x}$ & $\mathrm{x}$ & $\mathbf{x}$ & $\mathbf{x}$ & Trip blank \\
\hline 850 & $\mathbf{X}$ & & & $\mathbf{X}$ & $\mathbf{x}$ & $\mathbf{X}$ & $\mathbf{X}$ & $\mathbf{X}$ & $\mathbf{X}$ & $\mathbf{x}$ & Trip blank \\
\hline 851 & $\mathbf{x}$ & & & $\mathbf{x}$ & $\mathbf{x}$ & $\mathrm{X}$ & $\mathbf{X}$ & $\mathbf{X}$ & $\mathbf{x}$ & $\mathbf{X}$ & $\begin{array}{l}\text { Trip blank } \\
\text { Duplicate }^{c} \\
\end{array}$ \\
\hline 852 & $\mathbf{X}$ & & & $\mathbf{X}$ & $\mathbf{X}$ & $\mathbf{X}$ & $\mathbf{X}$ & $\mathbf{x}$ & $\mathbf{X}$ & $\mathbf{x}$ & Trip blank \\
\hline 854 & $\mathbf{X}$ & & & $\mathbf{x}$ & $\mathbf{x}$ & $\mathrm{x}$ & $\mathrm{x}$ & $\mathrm{x}$ & $\mathbf{x}$ & $\mathbf{x}$ & Trip blank \\
\hline 855 & $\mathbf{X}$ & & & $\mathbf{x}$ & $\mathbf{x}$ & $\mathrm{X}$ & $\mathbf{x}$ & $\mathbf{x}$ & $\mathrm{x}$ & $\mathbf{x}$ & Trip blank \\
\hline 856 & $\mathbf{X}$ & & & $\mathbf{x}$ & $\mathbf{x}$ & $\mathrm{x}$ & $\mathbf{x}$ & $\mathbf{x}$ & $\mathbf{x}$ & $\mathbf{X}$ & Trip blank \\
\hline 857 & $\mathbf{x}$ & & & $\mathbf{x}$ & $\mathbf{x}$ & $\mathbf{x}$ & $\mathrm{x}$ & $\mathrm{x}$ & $\mathbf{X}$ & $\mathbf{X}$ & Trip blank \\
\hline 858 & $\mathbf{X}$ & & & $\mathbf{X}$ & $\mathbf{X}$ & $\mathbf{X}$ & $\mathbf{X}$ & $x$ & $X$ & $\mathbf{X}$ & Trip blank \\
\hline 859 & $\mathrm{x}$ & & & $\mathbf{x}$ & $\mathbf{x}$ & $\mathrm{x}$ & $\mathbf{X}$ & $\mathbf{x}$ & $\mathrm{x}$ & $\mathrm{X}$ & Trip blank \\
\hline 860 & $\mathbf{X}$ & & & $\mathbf{x}$ & $x$ & $x$ & $\mathbf{x}$ & $\mathbf{x}$ & $\mathbf{x}$ & $\mathbf{x}$ & Trip blank \\
\hline 1036 & $\mathbf{x}$ & & & $\mathbf{X}$ & $X$ & $\mathrm{X}$ & $\mathbf{x}$ & $\mathbf{x}$ & $\mathbf{X}$ & $\mathrm{X}$ & Trip blank \\
\hline 1039 & $\mathbf{x}$ & & & $\mathbf{x}$ & $\mathbf{x}$ & $\mathbf{x}$ & $\mathrm{x}$ & $\mathrm{x}$ & $\mathbf{x}$ & $\mathbf{x}$ & $\begin{array}{l}\text { Trip blank } \\
\text { Duplicate }^{c}\end{array}$ \\
\hline 1166 & $\mathbf{X}$ & & & $\mathbf{X}$ & 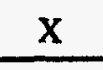 & $\mathbf{X}$ & $\mathrm{X}$ & $\mathbf{X}$ & $\mathbf{x}$ & $\mathrm{x}$ & Trip blank \\
\hline 1225 & $\mathbf{x}$ & & & $\mathbf{x}$ & $\mathbf{x}$ & $\mathrm{x}$ & $\mathbf{X}$ & $\mathbf{X}$ & $\mathbf{x}$ & $\mathrm{x}$ & Trip blank \\
\hline 1233 & $\mathbf{x}$ & & & $\mathbf{X}$ & $X$ & $\mathrm{X}$ & $\mathbf{X}$ & $\mathrm{X}$ & $\mathbf{X}$ & $\mathrm{X}$ & Trip blank \\
\hline 1237 & $\mathrm{X}$ & & & $\mathbf{X}$ & $x$ & $\mathbf{x}$ & $\mathrm{X}$ & $\mathrm{x}$ & $x$ & $\mathrm{X}$ & Trip blank \\
\hline 1241 & $\mathbf{x}$ & & & $\mathbf{X}$ & $x$ & $\mathrm{X}$ & $\mathbf{x}$ & $\mathbf{x}$ & $\mathbf{X}$ & $\mathbf{X}$ & Trip blank \\
\hline
\end{tabular}


Table B.3 (continued)

\begin{tabular}{|c|c|c|c|c|c|c|c|c|c|c|c|}
\hline \multicolumn{12}{|c|}{ Third Quarter List of Analytes } \\
\hline Well & $\begin{array}{l}\text { CLP" } \\
\text { Vols }\end{array}$ & $\begin{array}{l}\text { CLP } \\
\text { Svols }\end{array}$ & $\begin{array}{c}\text { CLP } \\
\text { Pest/PCBs }\end{array}$ & $\begin{array}{l}\text { CLP } \\
\text { Metals }\end{array}$ & $\begin{array}{l}\text { Gross } \\
\text { Alpha }\end{array}$ & $\begin{array}{c}\text { Gamma } \\
\text { Scan }\end{array}$ & ${ }^{3} \mathrm{H}$ & ${ }^{10} \mathrm{Sr}$ & $\begin{array}{l}\text { ICP Metals } \\
\text { (Filtered) }\end{array}$ & Herbicides & Field Quality Control Samples \\
\hline 1242 & $\mathbf{X}$ & & & $\mathbf{x}$ & $\mathbf{x}$ & $\mathbf{X}$ & $\mathrm{x}$ & $\mathbf{x}$ & $\mathbf{x}$ & $\mathbf{x}$ & Trip blank \\
\hline 1243 & $\mathbf{X}$ & & & $\mathbf{x}$ & $\mathbf{X}$ & $\mathbf{x}$ & $\mathbf{X}$ & $\mathbf{X}$ & $\mathbf{X}$ & $\mathbf{X}$ & Trip blank \\
\hline NWQ-1 & $\mathbf{X}$ & & & $\mathbf{x}$ & $\mathbf{X}$ & $\mathbf{X}$ & $\mathbf{X}$ & $\mathbf{X}$ & $\mathbf{X}$ & $\mathbf{x}$ & Trip blank \\
\hline NWQ-2 & $\mathbf{x}$ & & & $\mathbf{x}$ & $\mathbf{x}$ & $\mathbf{x}$ & $\mathbf{x}$ & $\mathbf{x}$ & $\mathbf{x}$ & $\mathbf{x}$ & Trip blank \\
\hline NWQ-3 & $\mathbf{X}$ & & & $\mathbf{x}$ & $\mathbf{X}$ & $\mathbf{X}$ & $\mathbf{X}$ & $\mathbf{X}$ & $\mathbf{X}$ & $\mathbf{x}$ & $\begin{array}{l}\text { Trip blank } \\
\text { Spike }(\mathbf{s})^{d} \\
\text { Duplicater }^{r}\end{array}$ \\
\hline NWQ-4 & $\mathrm{x}$ & & & $\mathbf{x}$ & $\mathbf{X}$ & $\mathbf{x}$ & $\mathbf{x}$ & $\mathbf{x}$ & $\mathbf{x}$ & $\mathrm{x}$ & Trip blank \\
\hline NWQ-5 & $\mathbf{X}$ & & & $\mathbf{x}$ & $\mathbf{X}$ & $\mathrm{X}$ & $\mathbf{X}$ & $\mathbf{X}$ & $x$ & $\mathrm{X}$ & Trip blank \\
\hline NWQ-6 & $\mathbf{x}$ & & & $\mathbf{x}$ & $\mathbf{x}$ & $\mathbf{x}$ & $\mathrm{X}$ & $\mathbf{x}$ & $\mathbf{X}$ & $\mathbf{x}$ & $\begin{array}{l}\text { Trip blank } \\
\text { Duplicate }^{2}\end{array}$ \\
\hline
\end{tabular}

$\mathrm{XX}$

${ }^{a}$ CLP volatiles include RCRA volatiles.

${ }^{t}$ Third quarter trip blanks will be analyzed for CLP volatiles only.

'Duplicate samples will be analyzed for the same constituents for which the original sample is analyzed.

${ }^{d}$ Spike samples will be used by the laboratory as a duplicate/spike combination for inorganics and as a spike/spike duplicate combination for organics. 
Table B.4. List of analytes, by well, for fourth-quarter groundwater quality monitoring at WAG 6

\begin{tabular}{|c|c|c|c|c|c|c|c|c|c|c|c|c|}
\hline \multicolumn{13}{|c|}{ Fourth Quarter List of Analytes } \\
\hline Well & CLP Vols" & CLP Svols & CLLP Pest/PCBs & $\begin{array}{l}\text { CLP } \\
\text { Metals }\end{array}$ & $\begin{array}{l}\text { Gross } \\
\text { Alpha } \\
\end{array}$ & $\begin{array}{c}\text { Ganima } \\
\text { ccan } \\
\end{array}$ & ${ }^{{ } \mathrm{H}}$ & ${ }^{{ }_{S} \mathrm{~S}_{\mathrm{r}}}$ & $\begin{array}{c}\text { ICP Metals } \\
\text { (Filtered) }\end{array}$ & $\begin{array}{l}\text { DOC } \\
\text { DIC }\end{array}$ & Alkatinity & $\begin{array}{c}\text { Field Quality } \\
\text { Control Samples }\end{array}$ \\
\hline 648 & $\mathrm{x}$ & & & $\mathbf{x}$ & $\mathrm{x}$ & $\mathrm{x}$ & $\mathrm{x}$ & $\mathbf{X}$ & $\mathbf{x}$ & & & Trip blank ${ }^{b}$ \\
\hline 745 & $\mathbf{x}$ & & & $\mathbf{x}$ & $\mathrm{x}$ & $x$ & $\mathbf{x}$ & $\mathbf{x}$ & $x$ & & & Trip blank \\
\hline 831 & $\mathbf{x}$ & & & $\mathbf{x}$ & $\mathbf{x}$ & $\mathrm{x}$ & $\mathbf{x}$ & $\mathbf{x}$ & $\mathbf{x}$ & & & Trip blank \\
\hline 832 & $\mathbf{x}$ & & & $\mathrm{x}$ & $\mathbf{x}$ & $\mathrm{x}$ & $\mathbf{x}$ & $\mathbf{x}$ & $\mathrm{X}$ & & & Trip blank \\
\hline 833 & $\mathbf{x}$ & & & $\mathbf{x}$ & $\mathrm{x}$ & $\mathrm{x}$ & $\mathbf{x}$ & $\mathrm{x}$ & $\mathrm{x}$ & & & Trip blank \\
\hline 835 & $\mathrm{x}$ & & & $\mathbf{x}$ & $\mathrm{x}$ & $\mathrm{x}$ & $\mathbf{x}$ & $\mathrm{x}$ & $\mathrm{x}$ & & & Trip blank \\
\hline 836 & $\mathrm{x}$ & & & $\mathbf{x}$ & $\mathrm{x}$ & $\mathrm{x}$ & $\mathrm{x}$ & $\mathbf{x}$ & $\mathrm{x}$ & & & Trip blank \\
\hline 837 & $\mathbf{x}$ & & & $\mathbf{x}$ & $\mathbf{x}$ & $\mathrm{x}$ & $\mathbf{x}$ & $\mathrm{x}$ & $\mathrm{x}$ & & & Trip blank \\
\hline 838 & $\mathrm{x}$ & & & $\mathrm{x}$ & $\mathrm{x}$ & $\mathbf{x}$ & $\mathbf{x}$ & $\mathrm{X}$ & $\mathrm{x}$ & & & Trip blank \\
\hline 839 & $\mathrm{x}$ & & & $\mathbf{x}$ & $\mathrm{x}$ & $\mathrm{x}$ & $\mathrm{x}$ & $\mathrm{x}$ & $\mathrm{x}$ & & 曾 & Trip blank \\
\hline 840 & $\mathbf{x}$ & & & $\mathrm{x}$ & $x$ & $\mathbf{x}$ & $\mathbf{x}$ & $\mathrm{x}$ & $x$ & & & Trip blank \\
\hline 841 & $\mathbf{x}$ & & & $\mathbf{x}$ & $\mathbf{x}$ & $\mathbf{x}$ & $\mathrm{x}$ & $\mathbf{x}$ & $\mathbf{x}$ & & & Trip blank \\
\hline 842 & $\mathrm{x}$ & & & $\mathrm{x}$ & $\mathrm{x}$ & $\mathbf{x}$ & $\mathrm{x}$ & $\mathbf{X}$ & $\mathbf{x}$ & & & Trip blank \\
\hline 843 & $\mathbf{x}$ & & & $\mathbf{x}$ & $\mathrm{x}$ & $\mathrm{x}$ & $\mathbf{x}$ & $\mathbf{x}$ & $\mathrm{x}$ & & & $\begin{array}{l}\text { Trip blank } \\
\text { Duplicate }\end{array}$ \\
\hline 844 & $\mathbf{X}$ & & & $\mathrm{x}$ & $\mathrm{x}$ & $\mathrm{x}$ & $\mathbf{x}$ & $\mathbf{x}$ & $x$ & & & Trip blank \\
\hline 845 & $\mathrm{x}$ & & & $\mathrm{x}$ & $\mathrm{X}$ & $\mathrm{X}$ & $\mathbf{x}$ & $\mathbf{X}$ & $\mathrm{x}$ & & & Trip blank \\
\hline 846 & $\mathbf{x}$ & & & $\mathbf{x}$ & $\mathbf{x}$ & $\mathrm{x}$ & $\mathbf{x}$ & $\mathrm{X}$ & $\mathrm{x}$ & & & Trip blank \\
\hline 847 & $\mathbf{x}$ & & & $\mathbf{x}$ & $\mathrm{x}$ & $\mathbf{x}$ & $\mathbf{x}$ & $\mathrm{x}$ & $\mathrm{x}$ & & & Trip blank \\
\hline
\end{tabular}


Table B.4 (continued)

\begin{tabular}{|c|c|c|c|c|c|c|c|c|c|c|c|c|}
\hline \multicolumn{13}{|c|}{ Fourth Quarter List of Analytes } \\
\hline Well & CLP Vols" & CLP Svols & CLP Pest/PCBs & $\begin{array}{l}\text { CLP } \\
\text { Metals }\end{array}$ & $\begin{array}{l}\text { Gross } \\
\text { Alpha } \\
\end{array}$ & $\begin{array}{c}\text { Gamma } \\
\text { Scan }\end{array}$ & ${ }^{3} \mathrm{H}$ & ${ }^{90} \mathrm{Sr}$ & $\begin{array}{l}\text { ICP Metals } \\
\text { (Filtered) }\end{array}$ & $\begin{array}{l}\text { DOC } \\
\text { DIC }\end{array}$ & Alkalinity & $\begin{array}{c}\text { Field Quality } \\
\text { Control Samples }\end{array}$ \\
\hline 848 & $\mathbf{x}$ & & & $\mathbf{x}$ & $\mathbf{x}$ & $\mathbf{x}$ & $\mathbf{x}$ & $\mathbf{x}$ & $\mathbf{x}$ & & & Trip blank \\
\hline 849 & $\mathrm{X}$ & & & $\mathbf{X}$ & $\mathbf{X}$ & $\mathbf{X}$ & $\mathrm{X}$ & $\mathbf{X}$ & $\mathbf{x}$ & & & Trip blank \\
\hline 850 & $\mathbf{X}$ & & & $\mathbf{X}$ & $\mathrm{X}$ & $\mathbf{X}$ & $\mathrm{X}$ & $\mathbf{x}$ & $\mathbf{x}$ & & & Trip blank \\
\hline 851 & $\mathbf{X}$ & & & $\mathbf{X}$ & $\mathbf{x}$ & $\mathbf{x}$ & $\mathbf{x}$ & $\mathbf{x}$ & $\mathbf{x}$ & & & Trip blank \\
\hline 852 & $\mathbf{x}$ & & & $\mathbf{X}$ & $\mathbf{X}$ & $\mathrm{X}$ & $\mathbf{x}$ & $\mathbf{x}$ & $\mathbf{X}$ & & & Trip blank \\
\hline 854 & $\mathbf{x}$ & & & $\mathbf{x}$ & $\mathbf{X}$ & $\mathbf{x}$ & $\mathrm{x}$ & $\mathbf{x}$ & $\mathbf{x}$ & & & Trip blank \\
\hline 855 & $\mathbf{X}$ & & & $\mathrm{X}$ & $\mathbf{X}$ & $\mathbf{X}$ & $\mathrm{X}$ & $\mathbf{x}$ & $\mathrm{X}$ & & & Trip blank \\
\hline 856 & $\mathrm{X}$ & & & $\mathbf{X}$ & $\mathrm{X}$ & $\mathbf{x}$ & $\mathrm{X}$ & $\mathbf{x}$ & $\mathrm{X}$ & & & Trip blank \\
\hline 857 & $\mathbf{x}$ & & & $\mathbf{x}$ & $\mathbf{x}$ & $\mathbf{x}$ & $\mathrm{X}$ & $\mathbf{x}$ & $\mathrm{X}$ & & & Trip blank \\
\hline 858 & $\mathbf{X}$ & & & $\mathbf{X}$ & $\mathrm{X}$ & $\mathbf{X}$ & $\mathrm{x}$ & $\mathbf{x}$ & $\mathrm{X}$ & & & Trip blank \\
\hline 859 & $\mathbf{X}$ & & & $\mathbf{X}$ & $\mathrm{X}$ & $\mathbf{X}$ & $\mathrm{X}$ & $\mathbf{X}$ & $\mathrm{X}$ & & & Trip blank \\
\hline 860 & $\mathrm{X}$ & & & $\mathrm{X}$ & $\mathrm{X}$ & $\mathbf{x}$ & $\mathbf{x}$ & $\mathbf{X}$ & $\mathbf{X}$ & & & Trip blank \\
\hline 1036 & $\mathbf{x}$ & & & $\mathbf{x}$ & $\mathrm{x}$ & $\mathbf{x}$ & $x$ & $\mathrm{x}$ & $x$ & & & $\begin{array}{c}\text { Trip blank } \\
\text { Spike(s) } \\
\text { Duplicate }^{2}\end{array}$ \\
\hline 1039 & $\mathrm{x}$ & & & $\mathbf{x}$ & $\mathbf{x}$ & $\mathbf{x}$ & $\mathrm{X}$ & $\mathbf{X}$ & $\mathbf{x}$ & & & Trip blank \\
\hline 1166 & $\mathbf{x}$ & & & $\mathbf{X}$ & $\mathbf{X}$ & $\mathbf{x}$ & $\mathbf{x}$ & $\mathbf{x}$ & $\mathbf{x}$ & & & Trip blank \\
\hline 1225 & $\mathbf{X}$ & & & $\mathrm{X}$ & $\mathbf{X}$ & $\mathbf{x}$ & $\mathbf{x}$ & $\mathbf{x}$ & $\mathrm{X}$ & & & Trip blank \\
\hline 1233 & $\mathbf{X}$ & & & $\mathbf{x}$ & $\mathbf{X}$ & $\mathrm{X}$ & $\mathbf{x}$ & $\mathrm{X}$ & $\mathbf{X}$ & & & Trip blank \\
\hline 1237 & $\mathbf{X}$ & & & $\mathbf{x}$ & $\mathbf{X}$ & $\mathbf{X}$ & $\mathbf{X}$ & $\mathrm{x}$ & $\mathbf{X}$ & & & Trip blank \\
\hline
\end{tabular}


Table B.4 (continued)

\begin{tabular}{|c|c|c|c|c|c|c|c|c|c|c|c|c|}
\hline \multicolumn{13}{|c|}{ Fourth Quarter List of Analytes } \\
\hline Well & CLP Vols" & CLP Svols & CLP Pest/PCBs & $\begin{array}{l}\text { CLP } \\
\text { Metals }\end{array}$ & $\begin{array}{l}\text { Gross } \\
\text { Alpha }\end{array}$ & $\begin{array}{l}\text { Gamma } \\
\text { Scan }\end{array}$ & ${ }^{3} \mathbf{H}$ & ${ }^{v} \mathbf{S r}$ & $\begin{array}{l}\text { ICP Metals } \\
\text { (Filtered) }\end{array}$ & $\begin{array}{l}\text { DOC } \\
\text { DIC }\end{array}$ & Alkalinity & $\begin{array}{l}\text { Field Quality } \\
\text { Control Samples }\end{array}$ \\
\hline 1241 & $\mathbf{x}$ & & & $\mathbf{x}$ & $\mathbf{x}$ & $\mathbf{x}$ & $\mathbf{X}$ & $\mathbf{x}$ & $\mathbf{x}$ & & & Trip blank \\
\hline 1242 & $\mathbf{x}$ & & & $\mathbf{x}$ & $\mathbf{X}$ & $\mathrm{x}$ & $\mathbf{X}$ & $\mathbf{x}$ & $\mathbf{x}$ & & & Trip blank \\
\hline 1243 & $\mathbf{x}$ & & & $\mathbf{x}$ & $\mathbf{x}$ & $\mathbf{x}$ & $\mathbf{X}$ & $\mathbf{X}$ & $\mathbf{X}$ & & & Trip blank \\
\hline NWQ-1 & $\mathbf{x}$ & & & $\mathbf{x}$ & $\mathbf{x}$ & $\mathbf{x}$ & $\mathbf{x}$ & $\mathbf{x}$ & $\mathbf{x}$ & & & Trip blank \\
\hline NWQ-2 & $\mathbf{x}$ & & & $\mathbf{x}$ & $\mathbf{x}$ & $\mathbf{x}$ & $\mathbf{X}$ & $\mathbf{x}$ & $\mathbf{x}$ & & & $\begin{array}{l}\text { Trip blank } \\
\text { Duplicate }^{r}\end{array}$ \\
\hline NWQ-3 & $\mathbf{x}$ & & & $\mathbf{x}$ & $\mathbf{x}$ & $\mathbf{x}$ & $\mathbf{x}$ & $\mathbf{x}$ & $\mathbf{X}$ & & & Trip blank \\
\hline NWQ-4 & $\mathbf{X}$ & & & $\mathbf{x}$ & $\mathrm{X}$ & $\mathrm{x}$ & $\mathbf{X}$ & $\mathrm{X}$ & $\mathbf{X}$ & & & Trip blank \\
\hline NWQ-5 & $\mathbf{X}$ & & & $\mathbf{x}$ & $\mathrm{x}$ & $\mathbf{x}$ & $\mathbf{x}$ & $\mathbf{x}$ & $\mathrm{X}$ & & & Trip blank \\
\hline NWQ-6 & $\mathbf{X}$ & & & $\mathbf{x}$ & $\mathrm{x}$ & $\mathrm{x}$ & $\mathbf{x}$ & $\mathbf{x}$ & $\mathbf{x}$ & & & Trip blank \\
\hline
\end{tabular}

${ }^{a}$ CLP volatiles include RCRA volatiles.

${ }^{b}$ Fourth quarter trip blanks will be analyzed for CLP volatiles only.

'Duplicate samples will be analyzed for the same constituents for which the original sample is analyzed.

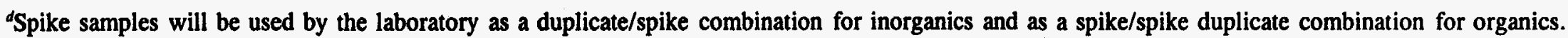




\section{APPENDIX C \\ SITE-SPECIFIC HAZARD EVALUATION ADDENDUM FOR \\ WAG 6 GROUNDWATER QUALITY \\ SAMPLING AND ANALYSIS PLAN}


SITE-SPECIFIC HAZARD EVALUATION ADDENDUM FOR WAG 6 GROUNDWATER QUALITY SAMPLING AND ANALYSIS PLAN

Si) ikon Her $2125(44)$

S. D. Van Hoesen

ER WAG 6 Project Manager

Q.w. Sautsting $2 / 14 / 94$

A. W. Saulsbury

ORNL HAZWOPER Program

Coordinator

WC $C$ Hayes $2 / 2 y / 24$

ORNL Applied Health Physicist

G. S. m) der $2 / 24 / 94$

ORNL Industrial Safety

28 Relucent: 2/21/44

T. S. Abercrombie

Laboratory Paptection

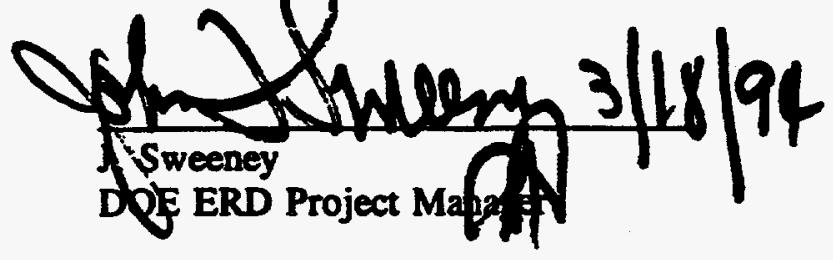

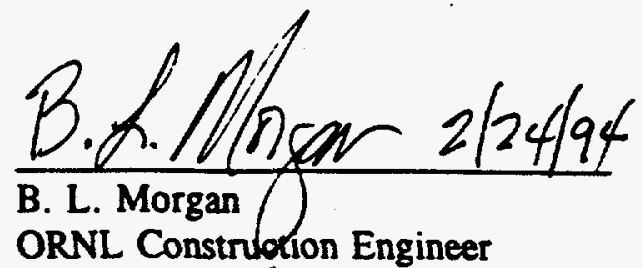

ORNL Constrotorion Engineer

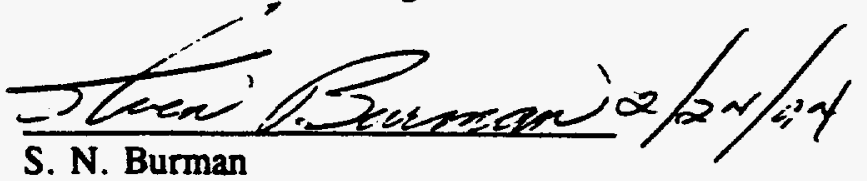

Site Safety and Health Manager

Kink a. Golden z/25/94

WAG 6 Facility Manager

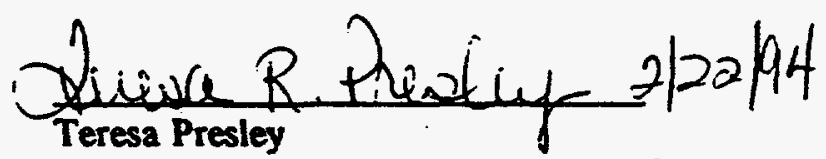

ORNL IH Divisional Representative for

Environmental Surveillance Division

Circe che 2128194

C. Clark, Jr.

Environmental Restoration Office 


\section{SITE-SPECIFIC HAZARD EVALUATION ADDENDUM FOR WAG 6 GROUNDWATER QUALITY SAMPLING AND ANALYSIS PLAN}

This Site-Specific Hazard Evaluation Addendum is for the performance of the Waste Area Grouping (WAG) 6 groundwater quality sampling and analysis plan. The work will be conducted by CDM Federal Programs Corporation (CDM Federal) and associated Oak Ridge National Laboratory (ORNL) environmental, safety, and health support groups. This activity will fall under the scope of 29 CFR 1910.120, Hazardous Waste Operations and Emergency Response (HAZWOPER). The purpose of this document is to establish site-specific health and safety guidelines to be followed by all personnel involved in conducting work for this project. Work will be conducted in accordance with requirements as stipulated in the ORNL HAZWOPER Program Manual, WAG 6 Site Health and Safety Plan (HASP), this addendum, and applicable ORNL, Martin Marietta Energy Systems, Inc. (Energy Systems), and U.S. Department of Energy (DOE) policies and procedures. The WAG 6 Site HASP and this addendum serve as an extension of the ORNL HAZWOPER Program Manual; combined, they fulfill the requirements of 29 CFR 1910.120 .

The levels of protection and the procedures specified in this plan are based on the best information available from historical data and preliminary evaluations of the area. Therefore, these recommendations represent the minimum health and safety requirements to be observed by all personnel engaged in this project. Unforeseeable site conditions, changes in scope of work, or hazardous conditions not previously considered will warrant a reassessment of protection levels and controls stated. Minor changes, such as downgrade of personal protective equipment (PPE) or change in the model of a site instrument may be justified and documented in the site logbook by the Site Safety and Health Officer (SSHO). Significant changes will require revision of the HASP or this addendum and must have approval by the appropriate ORNL Environmental Restoration (ER) Environmental Safety and Health (ESH) Manager and the HAZWOPER Program Coordinator (HPC) before restart of site operations. 


\section{PROJECT AND SITE DESCRIPTION}

\subsection{PROJECT DESCRIPTION}

The groundwater-quality-monitoring network is composed of 45 wells. The sampling team is composed of an Environmental Surveillance Division (ESD) sampling crew, a CDM Federal sample task leader (STL), and Industrial Hygiene-Health Physics (IHHP) personnel. Groundwater quality sampling requires the following steps: measuring the water level, purging the well, and obtaining the sample. Water level sampling guidelines, well sample locations, and data collection guidelines are discussed in Sect. 2 of the Groundwater Quality Sampling and Analysis Plan.

Water level measurements are obtained by removing the cap from the well, lowering the water level indicator probe into the well, and recording the reading. The well purging process is performed by removing from the well a volume of water equivalent to three well casings or by pumping the well to dryness. In completing the groundwater-quality-monitoring tasks, samples will be obtained after the well has been purged. Samples are collected directly from the bladder pumps; the samples are analyzed to determine levels of gross alpha activity, total radioactive strontium, gamma radiation, and tritium. Proper sample preservation techniques and overall groundwater sampling guidelines are located in Sect. 2 of the Groundwater Quality Sampling and Analysis Plan.

\subsection{SITE DESCRIPTION}

Information regarding the WAG 6 site description can be found in the Draft RCRA Facility Investigation Report for Waste Area Grouping 6 at Oak Ridge National Laboratory, Oak Ridge, Tennessee, ES/ER-22/V2\&D1 (Energy Systems 1991). 


\section{SITE ORGANIZATION AND COORDINATION}

The work will be performed by an ESD sampling crew and a CDM Federal STL. ORNL Industrial Hygiene (IH), Industrial Safety (IS), and Radiation Protection (RP) will provide appropriate health and safety services, including monitoring and oversight.

The following section details the organizational structure for this project. Key personnel and their project responsibilities are listed. An approved representative of the Measurement Applications and Development (MAD) Group will serve as the Site Safety and Health Officer (SSHO) and alternate SSHO.

In the event of a health and safety emergency, field personnel will contact the SSHO and/or the WAG 6 Project Engineer.

\subsection{SITE SAFETY AND HEALTH OFFICER}

The SSHO is the primary on-site contact for safety and health during field activities. The SSHO oversees the on-site execution of all field activities regarding safety and health procedures and has the authority to stop all work if conditions are judged to be hazardous to on-site personnel or to the public. The SSHO will remain at the project site at all times while workers are performing site activities. Other specific responsibilities are as follows.

1. Ensures that all on-site project personnel meet the required level of training, meet medical requirements including respirator fit test (as required), attend a pre-entry briefing on project and potential site hazards, and review the Work Plan and HASP. Maintains copies of this documentation at the project site and ensures that documentation is available for on-site review. Note: The ORNL Special Access Training Badge may be used as verification of training.

2. Requires personnel to obtain immediate medical attention in the case of a work-related injury or illness.

3. Denies access to all or any portion of the work area as warranted.

4. Orders work to cease, orders evacuation of the work area by all personnel, and reestablishes safe working conditions, as needed.

5. Controls access to the site by visitors and unauthorized personnel. Advises visitors and unauthorized personnel of their responsibilities, and ensures that they meet access requirements before their entry into the contamination reduction zone, exclusion zone, or controlled access areas is allowed.

6. Ensures the correct field execution of the Work Plan and HASP.

7. Ensures that this Work Plan and HASP are revised and approved if there are changes in site conditions or tasks. 
8. Advises emergency response personnel in an emergency.

9. Coordinates with IH, IS, and RP to establish site work zones level of required personnel protection, monitoring, and other controls.

10. Coordinates and minimizes the number of personnel and amount of equipment in the work zones.

11. Coordinates accident prevention by oversight of field activities and by awareness of all site operations.

12. Ensures that needed work permits are obtained and made available on site.

13. Ensures that the ER Program ESH Manager, HPC, IH, IS, and RP are contacted before commencement of site work (1) to notify of intent to begin work, and (2) to schedule monitoring support, as needed.

14. Conducts daily inspection of the work site.

15. Provides the HPC and ER Program ESH Manager with a list of personnel participating in site activities to determine the need for inclusion in the hazardous-waste-worker medical surveillance program.

16. Ensures that appropriate fall protection measures are in place, as warranted.

17. Ensures that an approved hoisting and rigging plan is available, as warranted.

18. Ensures that appropriate measures have been taken to prevent spills.

19. Ensures that appropriate monitoring/sampling services are available.

20. Ensures that the appropriate chain of command is followed in reporting safety and health issues.

21. Maintains Site Safety Logbook.

\subsection{FIELD PERSONNEL}

Specific responsibilities are as follows.

1. Take all reasonable precautions to prevent injury to themselves and to their fellow employees; be alert to potentially harmful situations.

2. Perform only those tasks that they believe they can do safely and immediately reporting any accidents and/or unsafe conditions to the SSHO.

3. Notify the SSHO of any special medical conditions (e.g., allergies, diabetes). 
4. Prevent spills to the extent possible. If a spill occurs, contain the spill, notify the SSHO, and clean up immediately using safe cleanup measures as directed by the SSHO. Note: Do not engage in spill containment or cleanup if conditions are not safe and if the cleanup cannot be accomplished with supplies available at the site. Evacuate the area. All spills must be reported to the ORNL Environmental Interface (574-8770).

5. Avoid splashing materials to the extent possible.

6. Practice good housekeeping by keeping the work area neat, clean, and orderly to the extent possible.

7. Report all injuries, no matter how minor.

8. Comply with the work plan and with the HASP and Addendum, as well as postings and rules at the project site.

9. Follow the appropriate chain of command for reporting and addressing health and safety issues.

\subsection{RADIATION PROTECTION (Jim Ed Irwin)}

ORNL Radiation Protection will be responsible for oversight and approval of personnel protection requirements related to radiation protection. A representative from the Office of Radiation Protection will review and approve the HASP before commencement of field activities. ORNL RP will be consulted before entry into any posted radiological area and will instruct field participants on requirements for that area, including the need for a Radiation Work Permit, appropriate monitoring, dosimetry, and PPE. The RP resentative will maintain an instrument calibration $\log /$ file in association with the Instrumentation and Calibration Department. The RP representative will be contacted for radiological concerns at the site that cannot be addressed by the SSHO or HP.

\subsection{INDUSTRIAL HYGIENE (Teresa Presley)}

The ORNL Industrial Hygiene Section and the HPC will be responsible for the oversight and approval of personnel protection related to industrial hygiene and the requirements of 29 CFR 1910.120 (HAZWOPER). The IH Divisional Representative and the HPC will review and approve the Work Plan and HASP before commencement of field activities. The IH representative and the HPC will provide guidance regarding PPE, and industrial hygiene monitoring and sampling requirements. The IH Section will be contacted for IH and HAZWOPER concerns at the site that cannot be addressed by the SSHO or HP.

\subsection{INDUSTRIAL SAFETY (Doug Miller)}

The ORNL Industrial Safety Section will be responsible for oversight and approval of personnel protection related to safety. A representative from IS will review and approve the Work Plan and HASP before commencement of field activities. IS will provide guidance 
regarding potential safety hazards, PPE, and safety requirements. The IS Section representative will be contacted for safety concerns at the site that cannot be addressed by the SSHO or HP.

A complete organizational structure and description of responsibilities may be found in Sect. 3 of the WAG 6 HASP.

\subsection{ENVIRONMENTAL RESTORATION PROGRAM ENVIRONMENTAL SAFETY AND HEALTH MANAGER (Charles Clark)}

The ORNL ER Program ESH Manager is a designated Energy Systems employee who is responsible for the oversight of all ORNL ER Program activities. The responsibilities of the ORNL ER Program ESH Manager include, but are not limited to,

- reviewing and approving all site safety and health plans and all site safety and health evaluation addendums,

- reviewing all self-assessment and -surveillance reports,

- providing interface between ER projects and the HPC, and

- reviewing and approving the qualifications of the Site Safety and Health Managers and SSHOs.

The ER Program ESH Manager provides a direct interface between field personnel and the HPC for safety and health issues that cannot be resolved at the ER Program level or the SSHO level. 


\section{PROJECT HAZARD EVALUATION}

Task: Groundwater quality sampling and analysis.

\subsection{PHYSICAL HAZARDS}
(X) Heat stress
(X) Cold stress
( ) Noise
( ) Confined space
( ) Enclosed space
( ) Manual lifting
(X) Tripping/falling
( ) Ergonomic
( ) High pressure
( ) Oxygen deficient
( ) Explosives/flammables
( ) Vibration
( ) Oxygen enriched
( ) Water

\subsection{SAFETY/CONSTRUCTION HAZARDS}
( ) Trenching
( ) Excavating
( ) Heavy equipment operation
( ) Demolition
( ) Elevated work
( ) Welding/cutting
( ) Hoisting/rigging
( ) Underground hazards
(X) Personnel decon
(X) Equipment decon
( ) Overhead hazards
( ) Drilling
( ) Drum handling
( ) ISU
(X) Environmental sampling
( ) Work in water/boat

\subsection{CHEMICAL HAZARDS}
(X) Volatile organics
( ) Inorganics
(X) Carcinogens
(X) Corrosives
( ) Reproductive toxicants
( ) Metals
( ) Mutagens
( ) Asbestos
( ) PCBs
( ) OSHA specific
( ) Flammables/explosives

\subsection{IONIZING RADIOLOGICAL HAZARDS}
( ) Internal exposure
(X) External exposure
(X) Contamination

\subsection{NON-IONIZING RADIOLOGICAL HAZARDS}
( ) UV
( ) RF
( ) Microwave
( ) Laser
( ) High voltage

\subsection{BIOLOGICAL/VECTOR HAZARDS}
( ) Wildlife
(X) Plants
( ) Medical waste
( ) Bacteria
(X) Parasites 


\subsection{DESCRIPTION OF HAZARDS AND CONTROLS}

\subsubsection{Physical Hazards}

Temperature Extremes

Task: Sampling on RCRA Caps.

Temperature extremes are of concern in two primary tasks that include heat stress while working in Tyvek PPE during the summer and early autumn months and include hypothermia while performing equipment decontamination during the winter.

Work load:

(X) Light

( ) Moderate

( ) Heavy

Precautions (specify): Decrease work load during extremely hot or cold days, and take frequent breaks to warm up or cool down. Increase water intake on extremely hot or cold days, and make frequent trips to either vehicles or trailers during cold days. The SSHO will adhere to the guidelines for temperature extremes listed in the American Conference of Government Industrial Hygienists publication. Threshhold Level Values for Chemical Substances, Physical Agents, and Biological Exposure Indices.

Cooling/heating equipment needed: No, vehicle is present at site.

\section{Ergonomic Hazards}

Task: Sampling on RCRA caps.

Heavy lifting ( ) Yes (X) No

Vibrating equipment () Yes (X) No

Tripping/falling (X) Yes ( ) No

Controls/protective equipment: The buddy system will be employed to monitor field personnel safety. Protective controls to assist in prevention of tripping and falling include shoe covers (black rubber boots). In addition, care will be taken while monitoring/sampling in areas where heavy dew or damp RCRA caps are possible.

\subsubsection{Chemical Hazards}

Substance: Hydrochloric acid ( $\mathrm{HCl})$

Use (for materials brought on site): Sample preservative

Location (for substances identified at the site): NA

TLV: NA PEL: $5 \mathrm{ppm}$ IDLH: $100 \mathrm{ppm}$ STEL: NA

Route of exposure: Inhalation, ingestion, contact/absorption 
Target organs: Respiratory system, eyes, skin
LEL:
NA UEL:
NA
FP:
NA

Signs and symptoms of exposure: Inflammation of nose and throat; coughing, burning sensation in eyes and on skin.

Health effects: May cause damage to the respiratory system or mucous membrane; may cause epidermal burns.

Additional comments and controls:

None

Substance: Nitric acid $\left(\mathrm{HNO}_{3}\right)$

Use (for materials brought on site): Sample preservative

Location (for substances identified at the site): NA

TLV: $2 \mathrm{ppm}$ PEL: $2 \mathrm{ppm}$ IDLH: $100 \mathrm{ppm}$ STEL: $10 \mathrm{mg} / \mathrm{m}^{3}$

Route of exposure: Inhalation, ingestion, contact (absorption)

Target organs: Eyes, skin, respiratory system, teeth
LEL: NA
UEL:
NA
FP:
NA

Signs and symptoms of exposure: Skin irritation or burning; irritation of eyes; irritated respiratory system (burning, coughing, choking)

Health Effects: _. May cause epidermal burns or discoloration: may cause damage to the respiratory system or mucous membrane

Additional comments and controls:

None

Substance: Liquinox

Use (for materials brought on site): Equipment decontamination

Location (for substances idemified at the site): NA

TLV: NA PEL: NA IDLH: NA STEL: NA

Route of exposure: Absorption, ingestion

Target organs: Eyes, skin

LEL: NA UEL: N NA FP: NA

Signs and symptoms of exposure: Redness or dryness of the skin; stomach discomfort or nausea if ingested.

Health Effects: NA

Additional comments and controls:

None

Substance: Deionized water

Use (for materials brought on site): Equipment decontamination

Location (for substances identified at the site): NA

TLV: NA PEL: NA IDLH: NA STEL: NA

Route of exposure: Ingestion

Target organs: NA

LEL: NA UEL: NA FP: NA

Signs and symptoms of exposure: NA

Health Effects: NA

Additional comments and controls:

None

More information regarding specific chemicals of concern at the site is provided in the tables at the end of this section. See Sea. 5 for Industrial Hygiene monitoring/sampling requirements. 


\subsubsection{Ionizing Radiation}

For ionizing radiological hazards identified in Sect. 3.4, the following information is provided. Available historical and site characterization data were used to complete this section. An Office of Radiation Protection representative was contacted to assist in completion of this section.

Additional information concerning ionizing radiation can be found in the tables at the end of this section.

Any known contamination present (from prior scanning or history)? $\quad$ (X) Yes $\quad$ ( ) No

Primary contaminating isotope(s): See tables

Radiation type: Alpha/beta/gamma

Location on site: Well number(s) 1242, 1243,843

Radiation work permit required? ( ) Yes (X) No

Dose rate: (weekly) $\quad 100 \mathrm{mR}$

Worker dose limit: $\quad 20 \mathrm{mR} /$ day

Contamination level (removable): Alpha $20 \mathrm{dpm}$

Beta/gamma $200 \mathrm{dpm}$

$\begin{array}{llr}\text { (fixed): } & \text { Alpha } & 200 \mathrm{dpm} \\ & \text { Beta/gamma } & 1000 \mathrm{dpm}\end{array}$

Note: Dose rate, worker dose limit, and contamination levels are administrative guidelines.

Airborne contamination concentration: $\mathrm{NA}_{\mathrm{N}} \mu \mathrm{Ci} / \mathrm{mL}$

Water contamination potential? $\quad(\mathrm{X})$ Yes $\quad($ ) No

Unrestricted airborne contamination release potential? ( ) Yes (X) No

Health Physics coverage: Continuous/Intermittent/Conditional

High volume sampling to be conducted?

Low volume sampling to be conducted?

Personal monitoring/sampling?
( ) Yes (X) No

(X) Yes ( ) No

(X) Yes ( ) No

Additional controls/requirements: None

Instruments to be used and monitoring requirements are identified in Sect. 5. 


\subsubsection{Sanitation}

Task: Groundwater quality sampline and analysis

A clean zone located on WAG 6 provides workers with an area for eating and drinking, toilet facilities, washing facilities (hand wash and emergency eye wash only), and a changing room.

Potable water required? Not permitted on work site

Nonpotable water used? Yes, for decontamination

Eating, drinking, chewing, use of tobacco permitted?

Location: As stated above.

Toilet facilities required?

Location and number: As stated above.

Washing facilities required?

Location: As stated above.

Change rooms required?

Specify: As stated above.

\subsubsection{Mumination}

Tasks: Groundwater ouality sampling and analysis

Additional illumination needed? ( ) Yes (X) No ( ) NA

All groundwater quality sampling and analysis activities will be performed during daylight hours. No additional illumination will be required. 




TAG 6 ZONE DIVISION

OAK moeE Hanomu Usoratomy OANL WAE : 
ZONE 1

Water Quality Wells

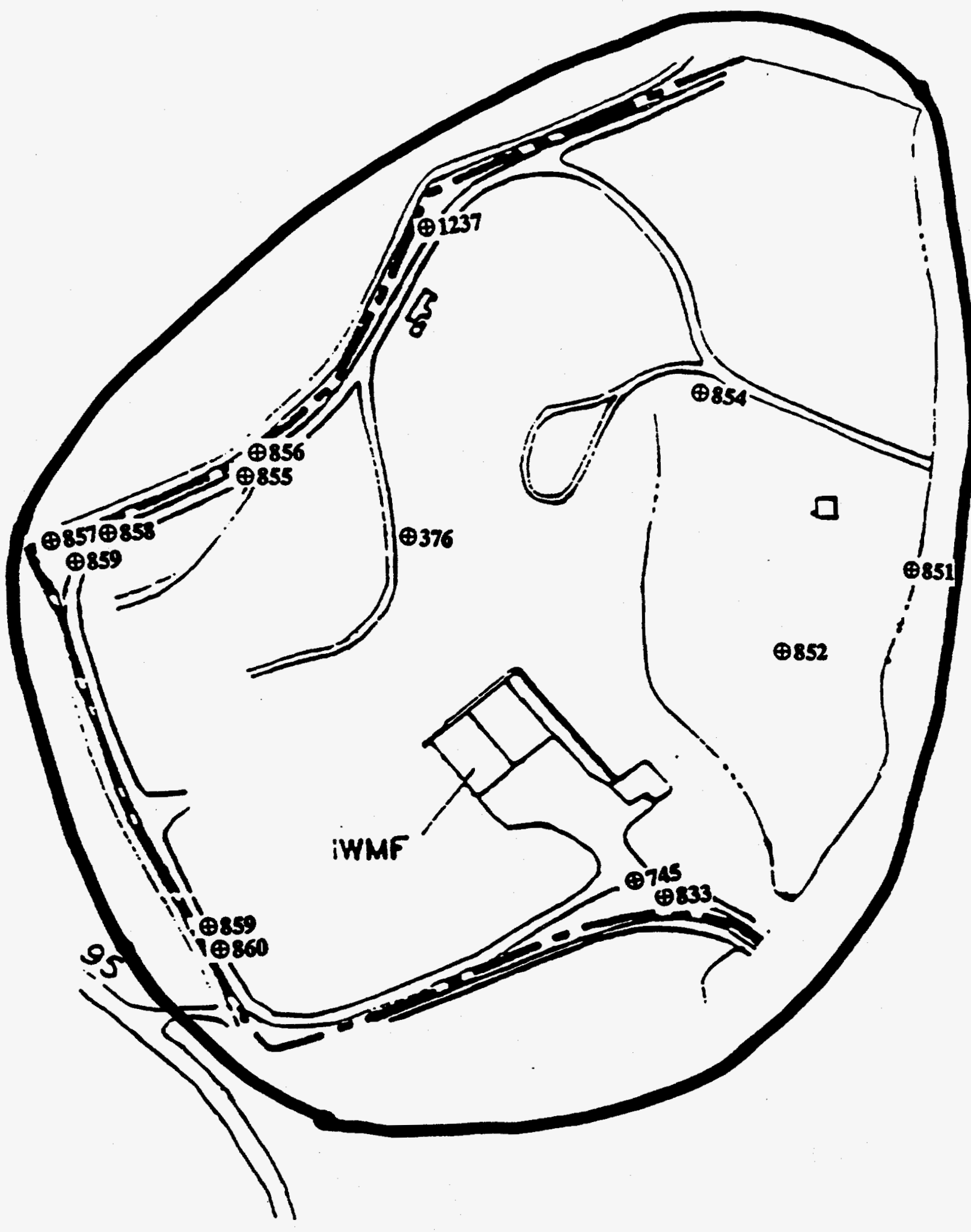

Oak Ridge National Laboratory

WAG - 6 
Zone 1 Contaminant List

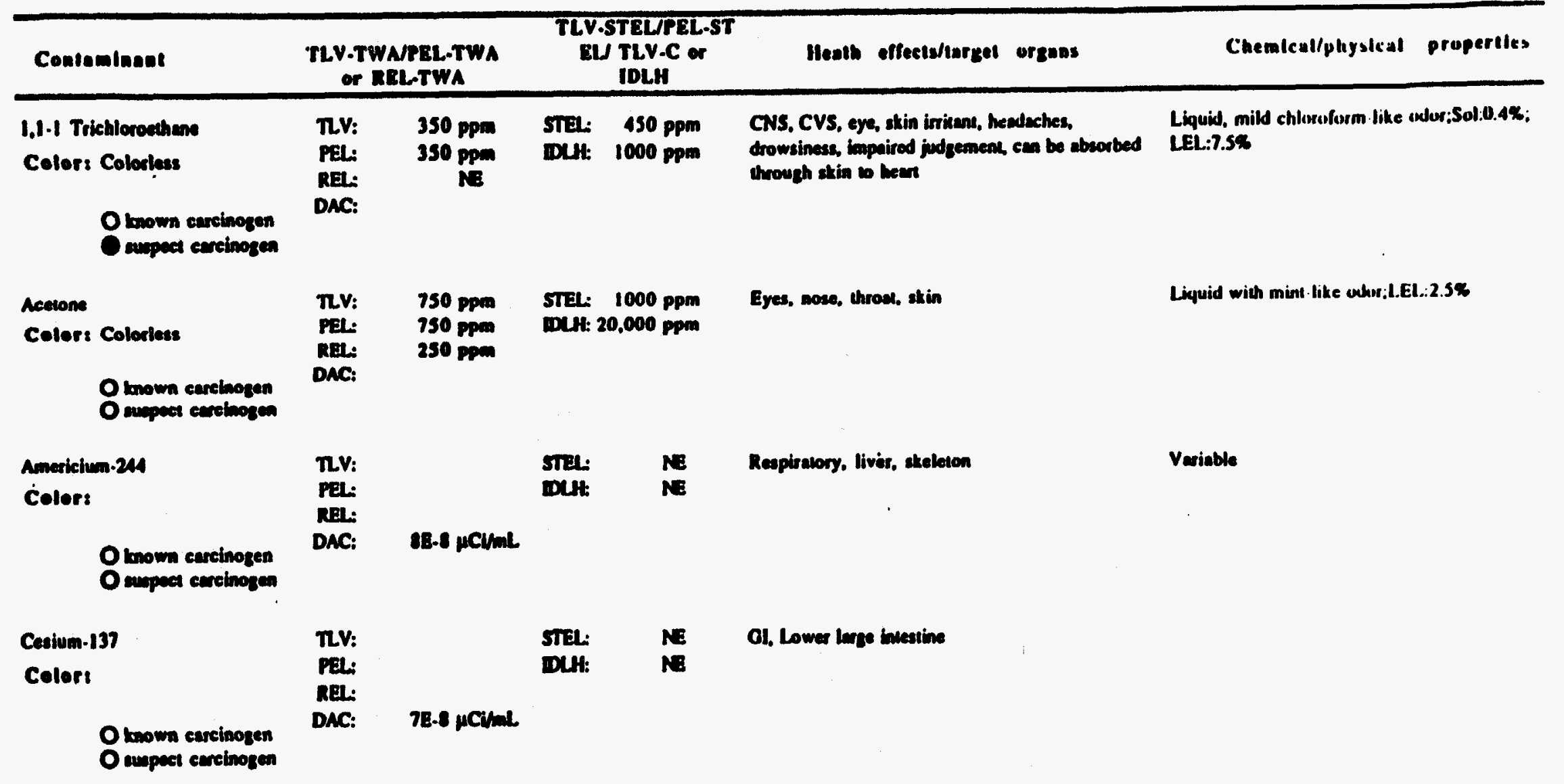

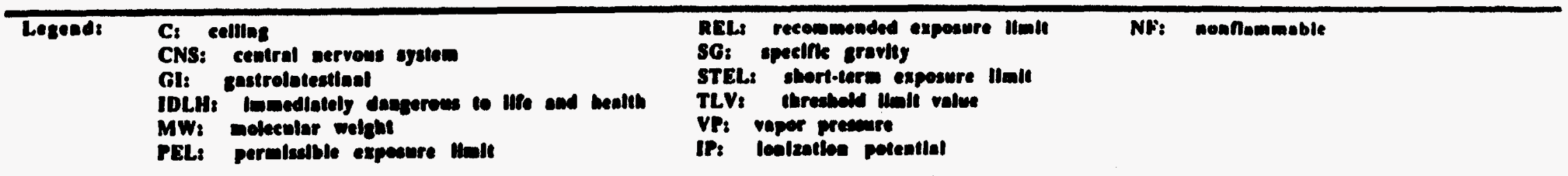

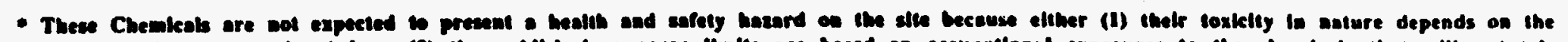

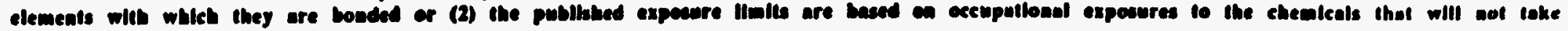
place is the envirenoment. 
Zone 1 Contaminant List

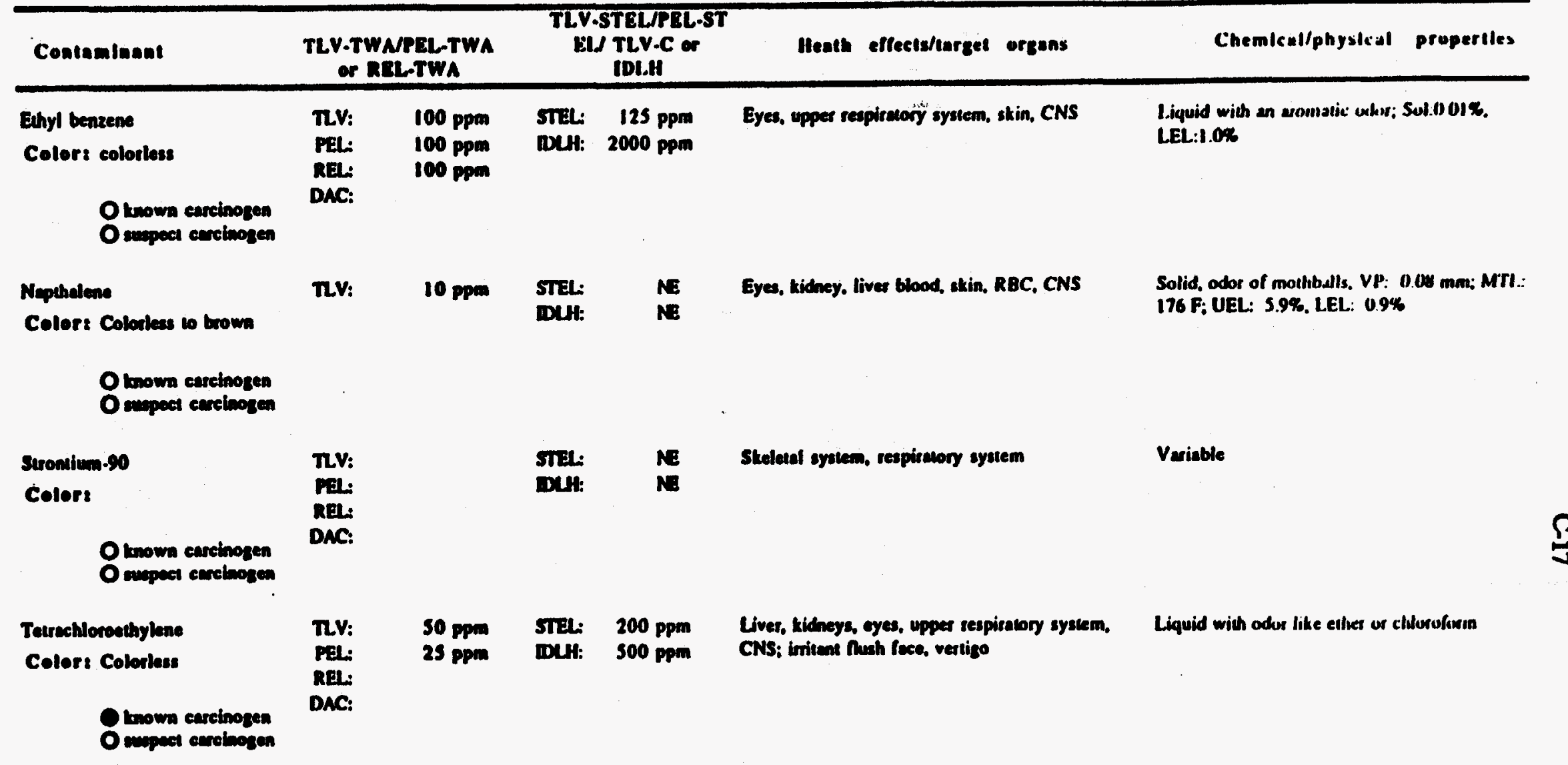

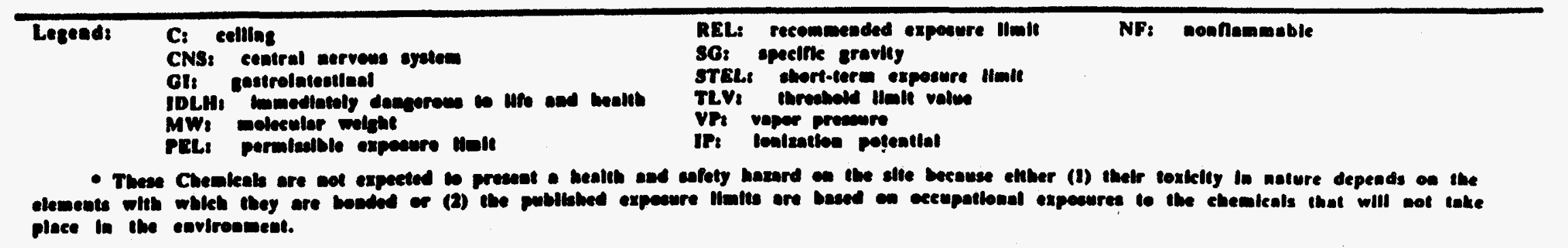


Zone 1 Contaminant list

\begin{tabular}{|c|c|c|c|c|c|c|}
\hline Contamianat & $\begin{array}{r}\text { TLV-T } \\
\text { or }\end{array}$ & $\begin{array}{l}\text { PEL-TWA } \\
\text { PTWA }\end{array}$ & ThV. & $\begin{array}{l}\text { STELAPEL.S } \\
\text { TLV.C or } \\
\text { IDI.II }\end{array}$ & Heats effecta/largel organs & Chemiculphyslcal propertles \\
\hline $\begin{array}{l}\text { Tetrachloroethylene } \\
\text { Color: Colorless }\end{array}$ & TLV: & 50 ppm & $\begin{array}{l}\text { STEL: } \\
\text { DLHI: }\end{array}$ & $\begin{array}{l}200 \mathrm{ppm} \\
500 \mathrm{ppm}\end{array}$ & $\begin{array}{l}\text { Liver, kidneys, eyes, upper respirubry syskem. } \\
\text { CNS; irrient flush fece, vertige }\end{array}$ & $\begin{array}{l}\text { Liquid with ocher like cthet or thlonoform: If: } \\
\text { 9.32; FP: 0; L.FL: munflaninalde: UFI.: } \\
\text { nonflammable }\end{array}$ \\
\hline $\begin{array}{l}\text { Tolvene } \\
\text { Color: Colorless } \\
\text { O known curcinogen } \\
\text { O mupeet carcinosen }\end{array}$ & $\begin{array}{l}\text { RLV: } \\
\text { PEL: } \\
\text { REL: } \\
\text { DAC: }\end{array}$ & $\begin{array}{l}100 \mathrm{ppm} \\
100 \mathrm{ppm} \\
100 \mathrm{pmm}\end{array}$ & $\begin{array}{l}\text { STEL: } \\
\text { DLH: }\end{array}$ & $\begin{array}{l}150 \mathrm{ppm} \\
2000 \mathrm{ppm}\end{array}$ & CNS, liver, tridneys, stin & $\begin{array}{l}\text { Liquid with sweel. pungent beneene tike ocho; } \\
\text { LEL:1.2\% }\end{array}$ \\
\hline $\begin{array}{l}\text { Trichlorecthylene } \\
\text { Colors Colorless }\end{array}$ & $\mathbf{R} \mathbf{V}:$ & 50 pom & $\begin{array}{l}\text { STEL: } \\
\text { DLH: }\end{array}$ & $1000 \mathrm{ppm}$ & $\begin{array}{l}\text { Respirckory, heart, skin; headeches, dermatitis, } \\
\text { nousen, vomitins }\end{array}$ & Linguid with a chlorofurill orker \\
\hline $\begin{array}{l}\text { Xylen } \\
\text { Celer: Colerless }\end{array}$ & ILV: & $100 \mathrm{ppm}$ & $\begin{array}{l}\text { STEL: } \\
\text { DLH: }\end{array}$ & $1000 \mathrm{ppm}$ & $\begin{array}{l}\text { CNS, Ot treet, liver, kidneys, skin; dizziness. } \\
\text { sugsering sait, nuser, stomech puin }\end{array}$ & Licquid with aromatic odker \\
\hline O brown carcinogen & & & & & 9 & \\
\hline
\end{tabular}

\begin{tabular}{|c|c|c|c|c|}
\hline Legendz & 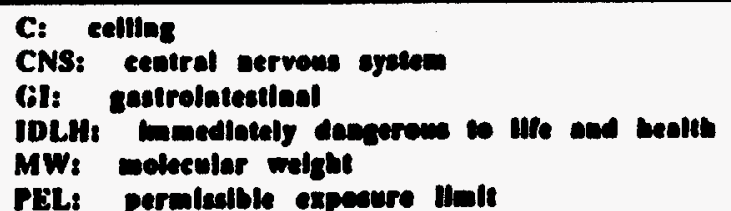 & 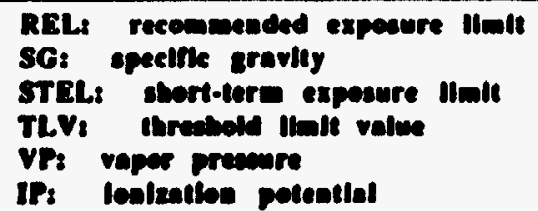 & NF: & moanammable \\
\hline
\end{tabular}

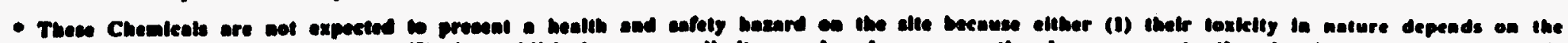

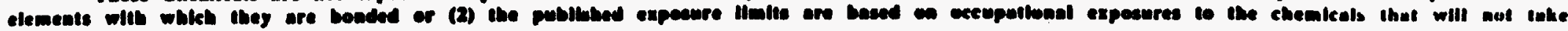
plece in the environment. 


\section{C.19}

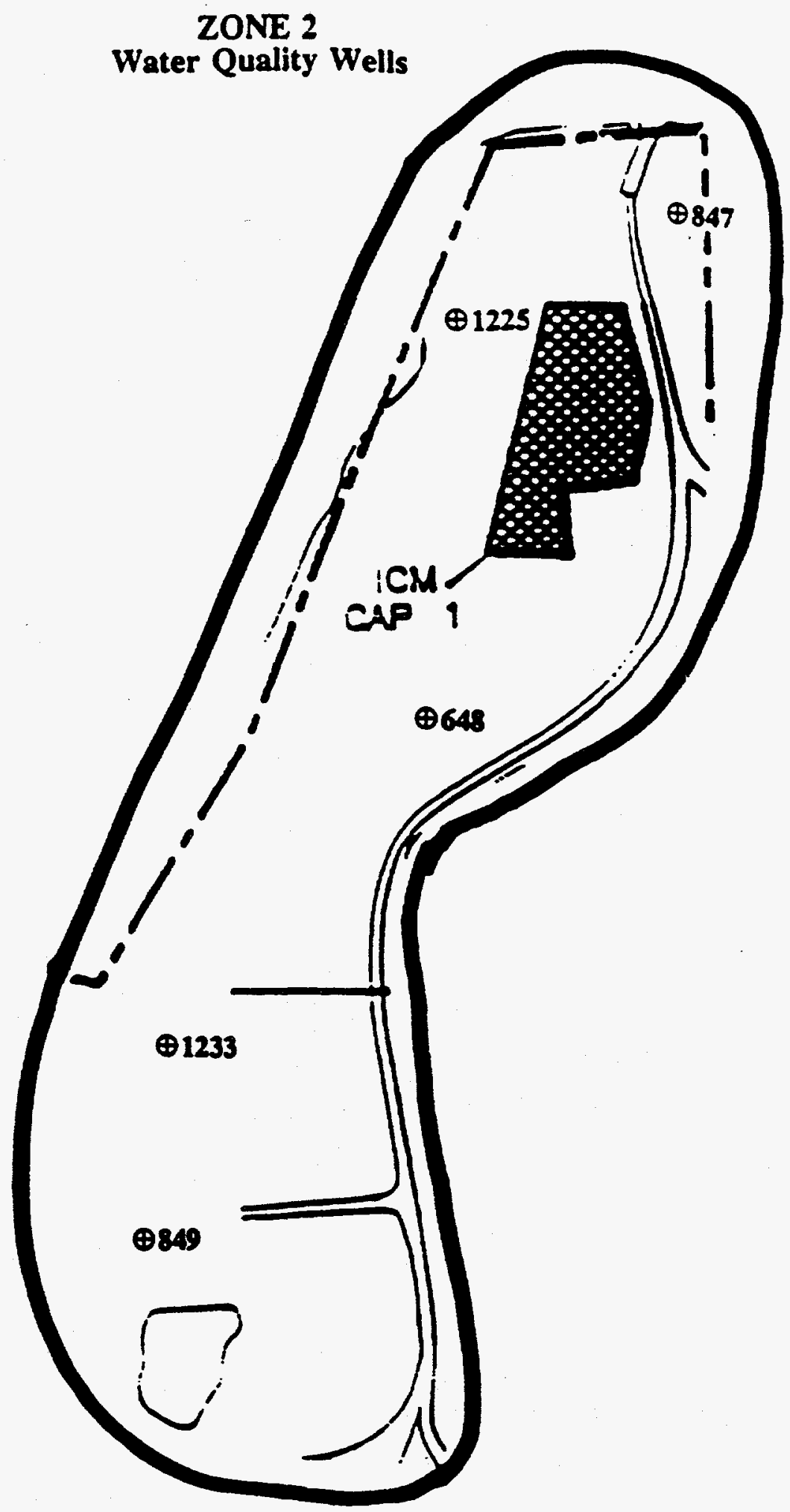

Oak Ridge National Laboratory

WAG - 6 
Zone 2 Contaminant List

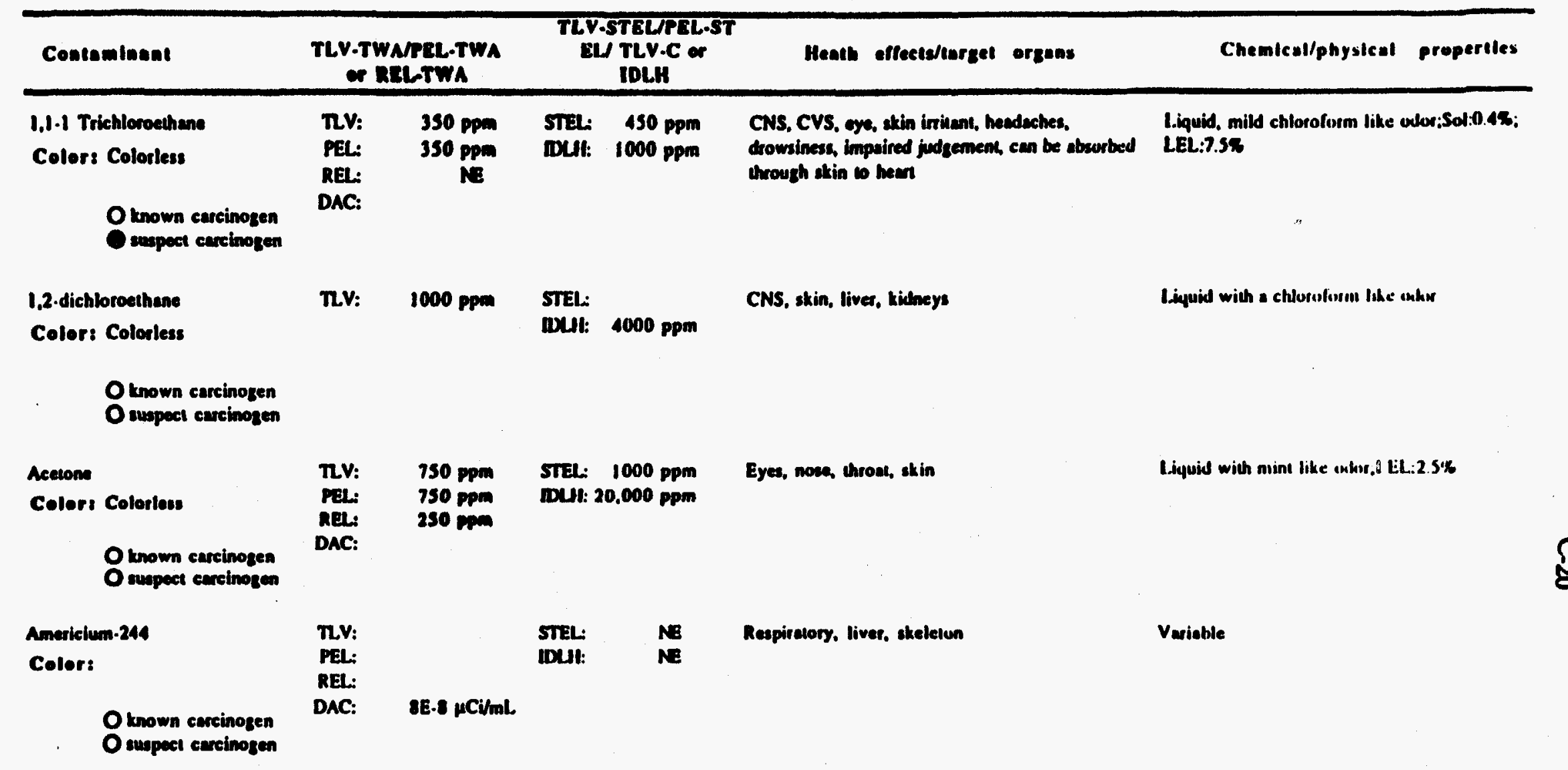

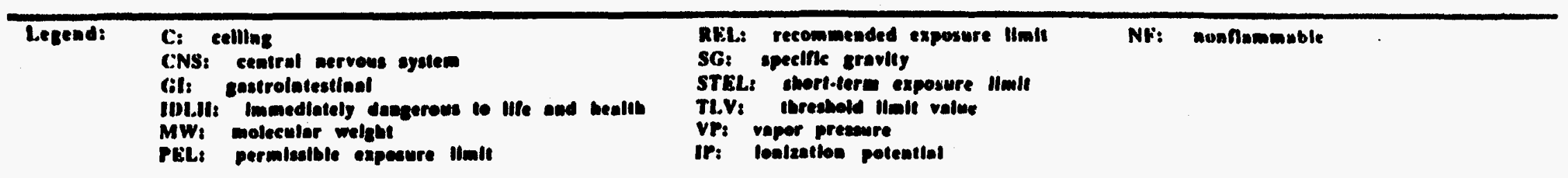

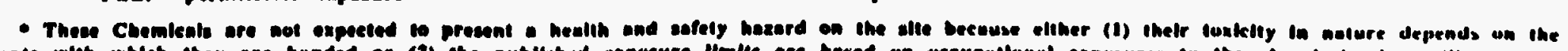

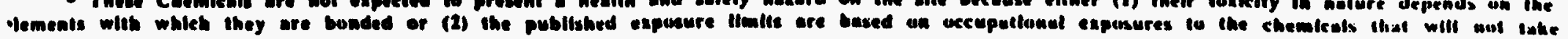
vce In the eavironment. 
Zone 2 Contaminant list

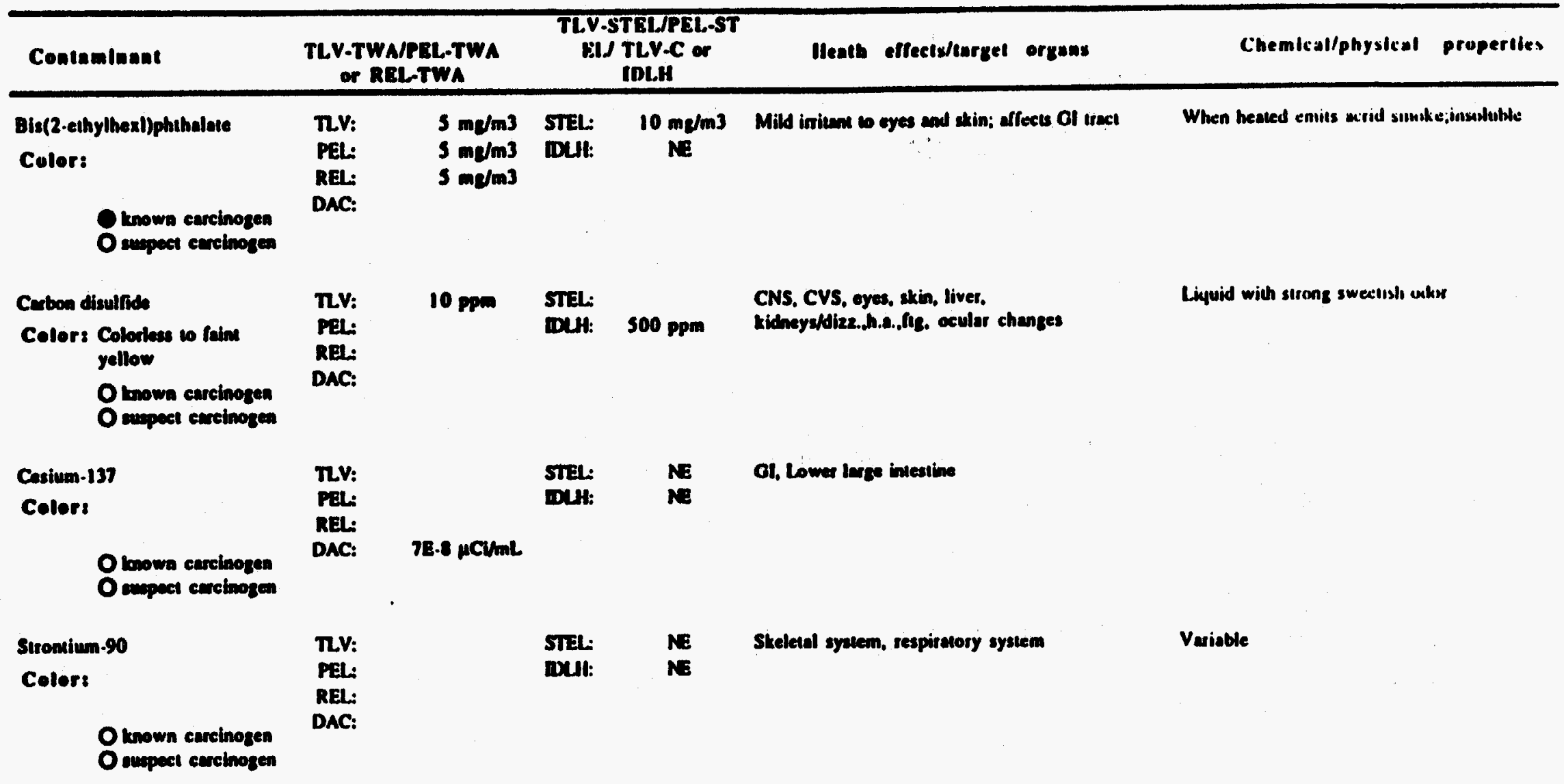

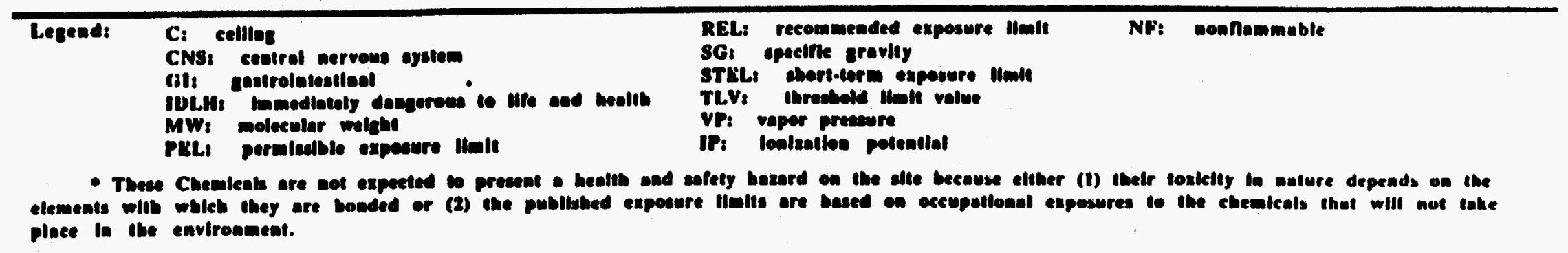


Zone 2 Contaminant Idist



Omperer carcinoten

\begin{tabular}{|c|c|c|c|c|}
\hline Legend: & 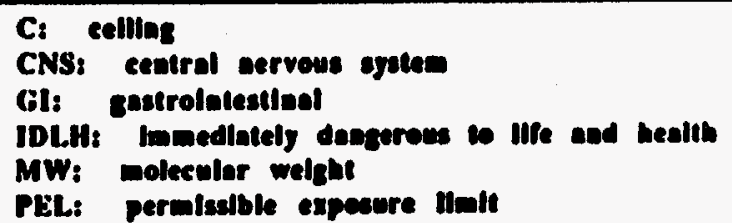 & 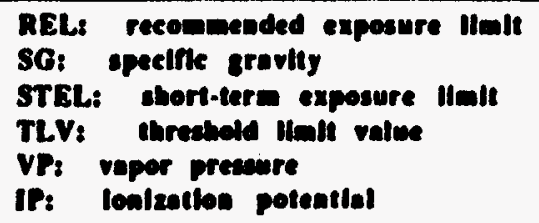 & NF: & monfremmable \\
\hline
\end{tabular}

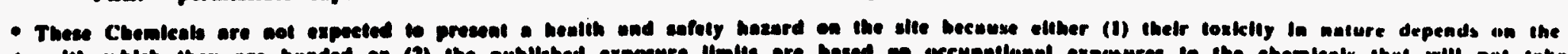

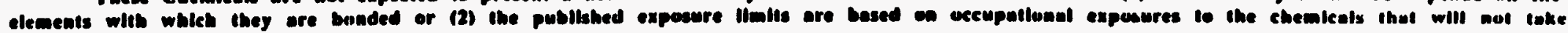
alace in the envirenment. 


\section{ZONE 3}

Water Quality Wells

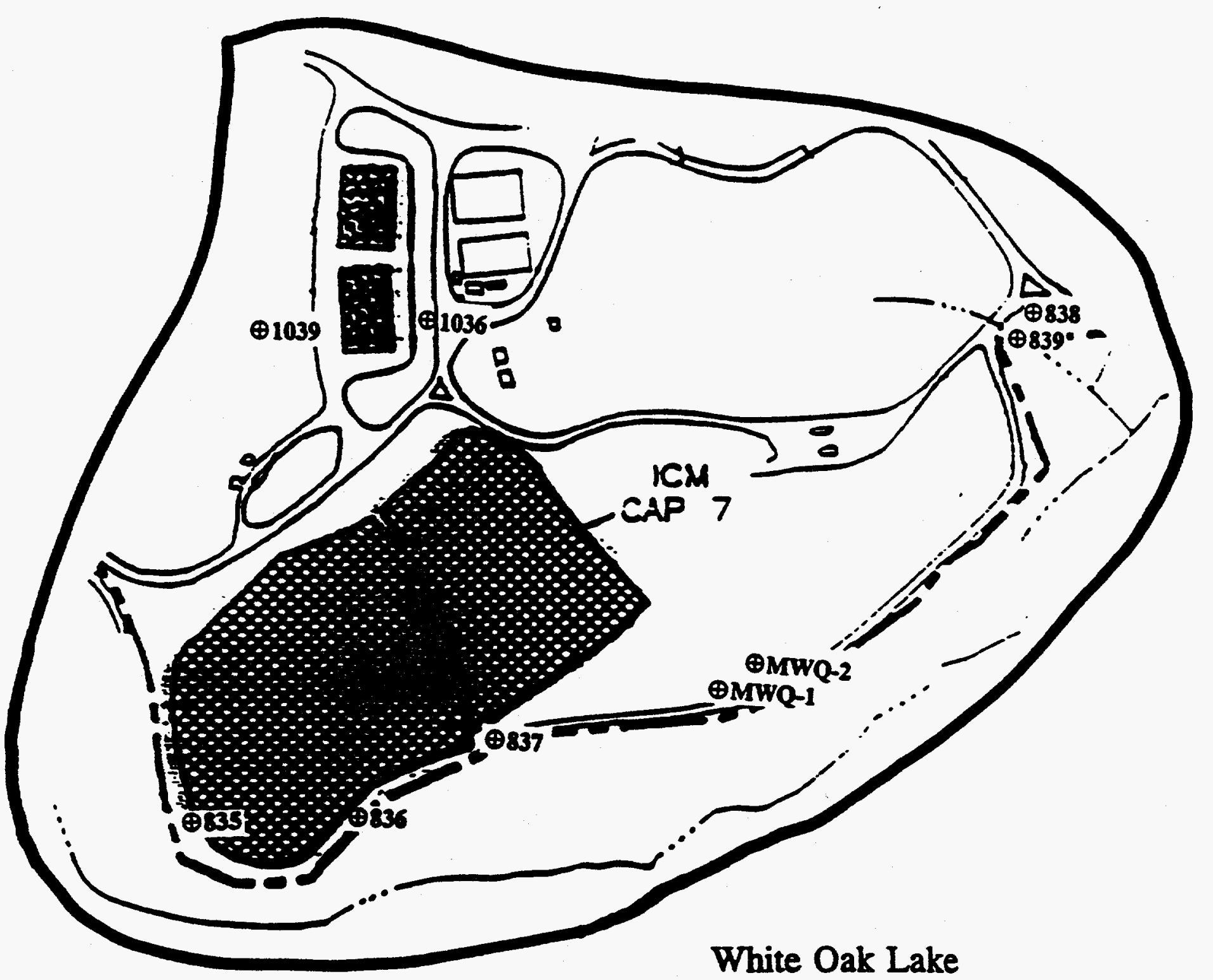

Oak Ridge National Laboratory

WAG - 6 
Zone 3 Contaminant List

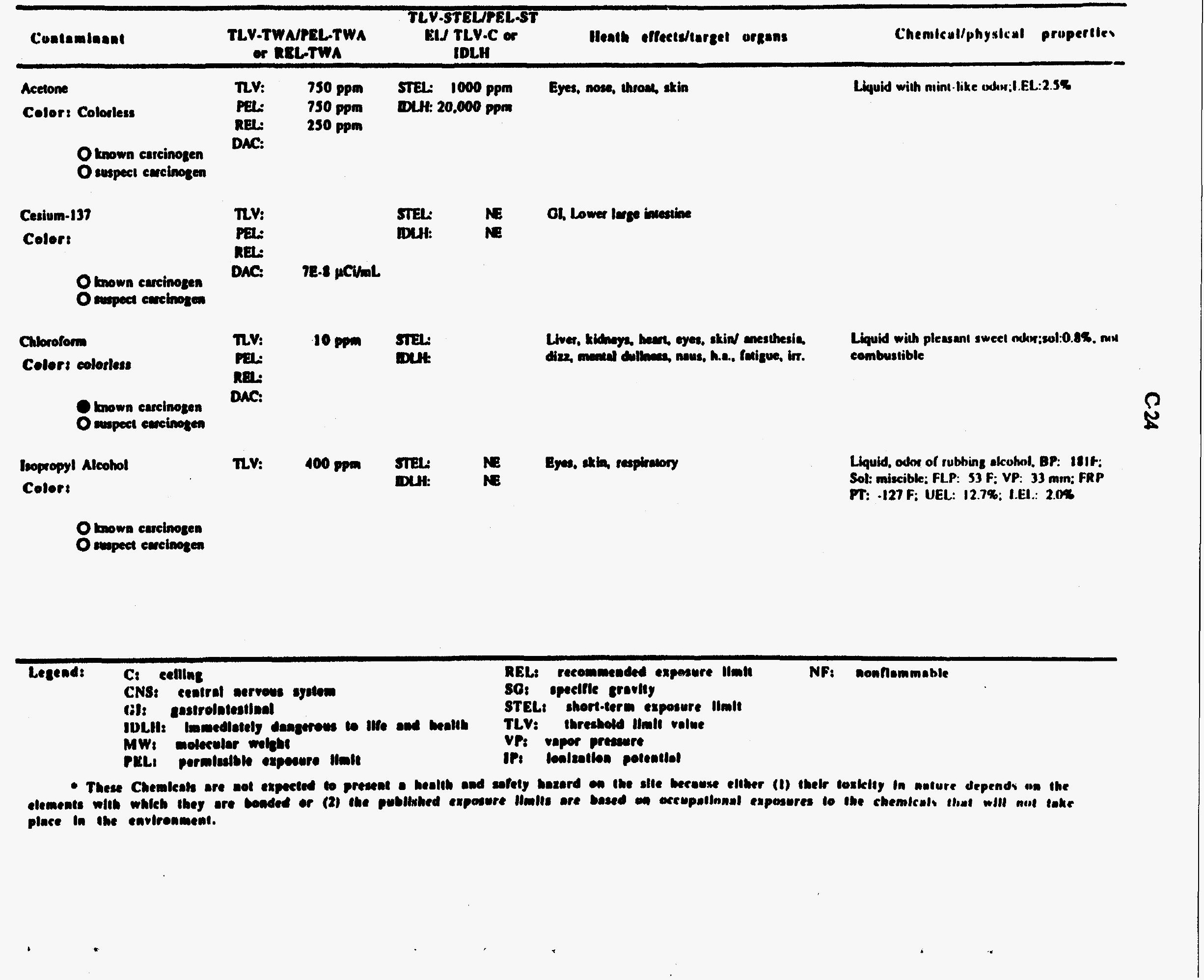


Zone 3 Contaminant List

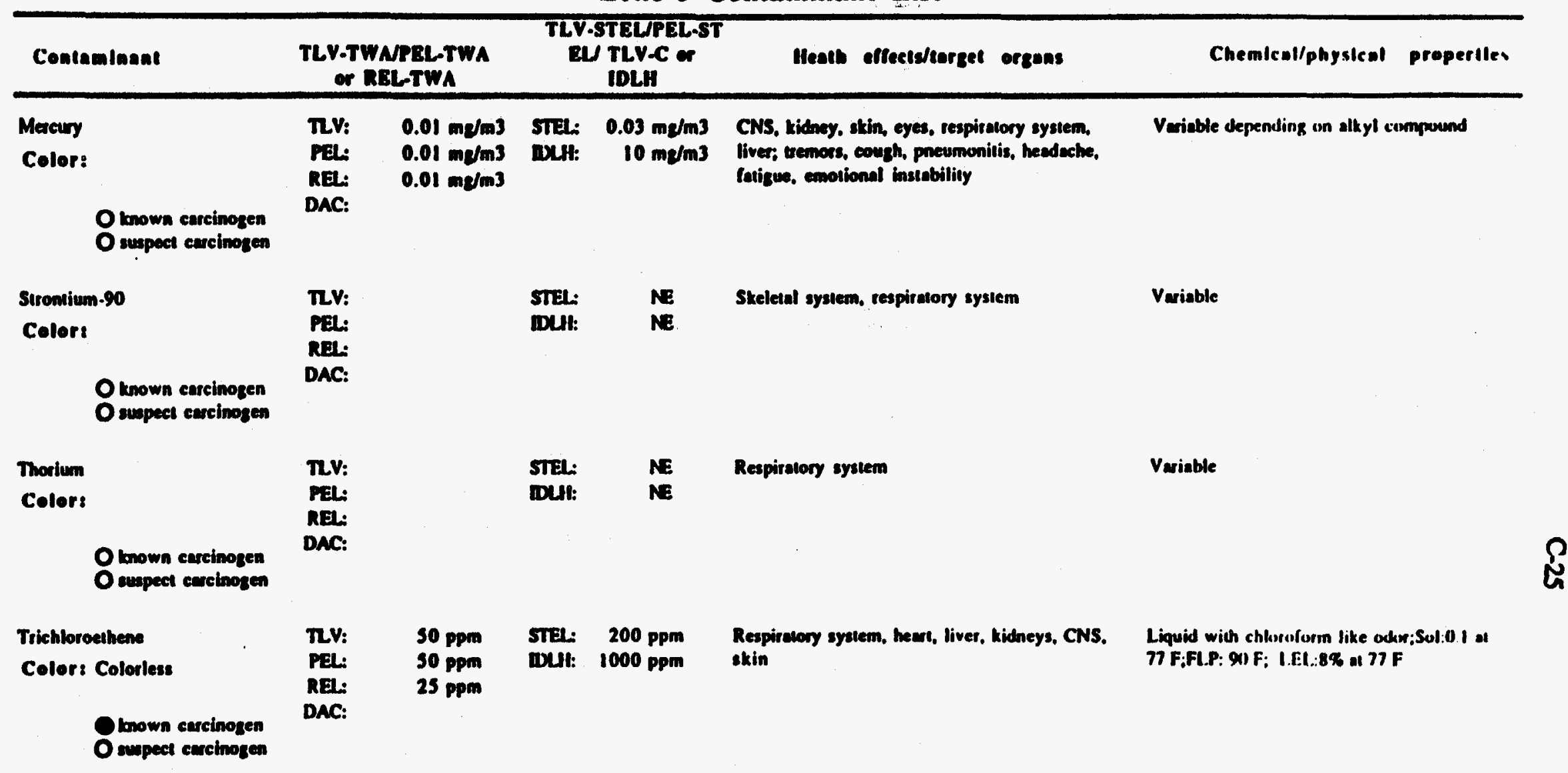

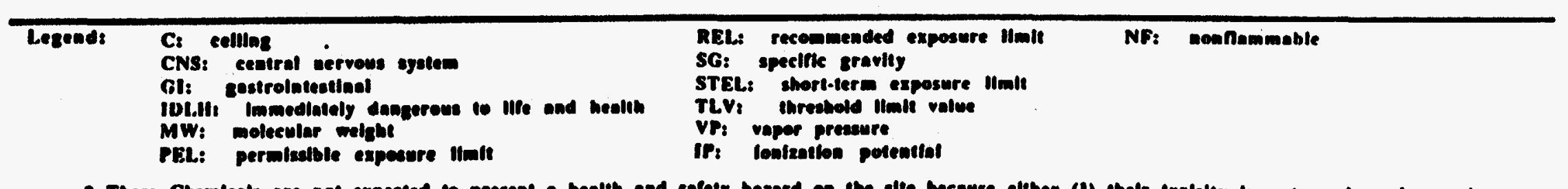

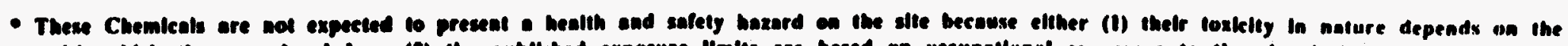

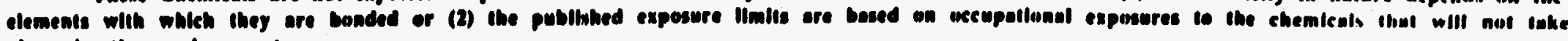
place in the environment. 
Zone 3 Contaminant List

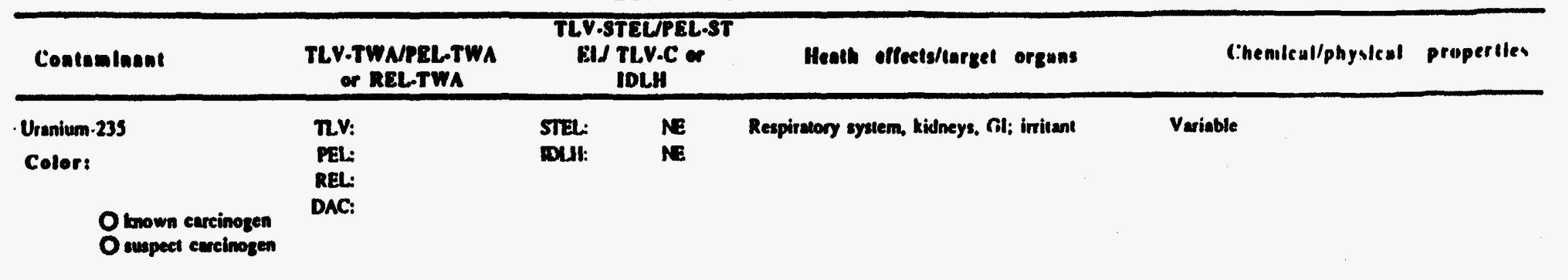

\begin{tabular}{|c|c|c|c|c|}
\hline Legends & 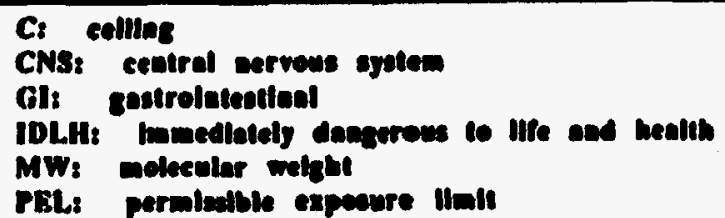 & 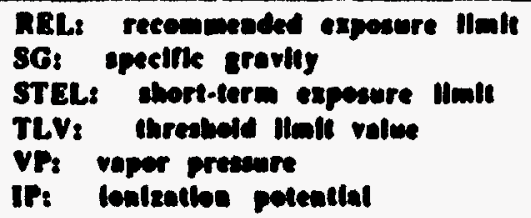 & NF: & meaffommable \\
\hline
\end{tabular}

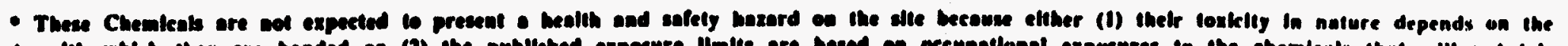

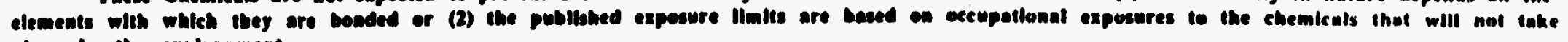
place in the environment. 


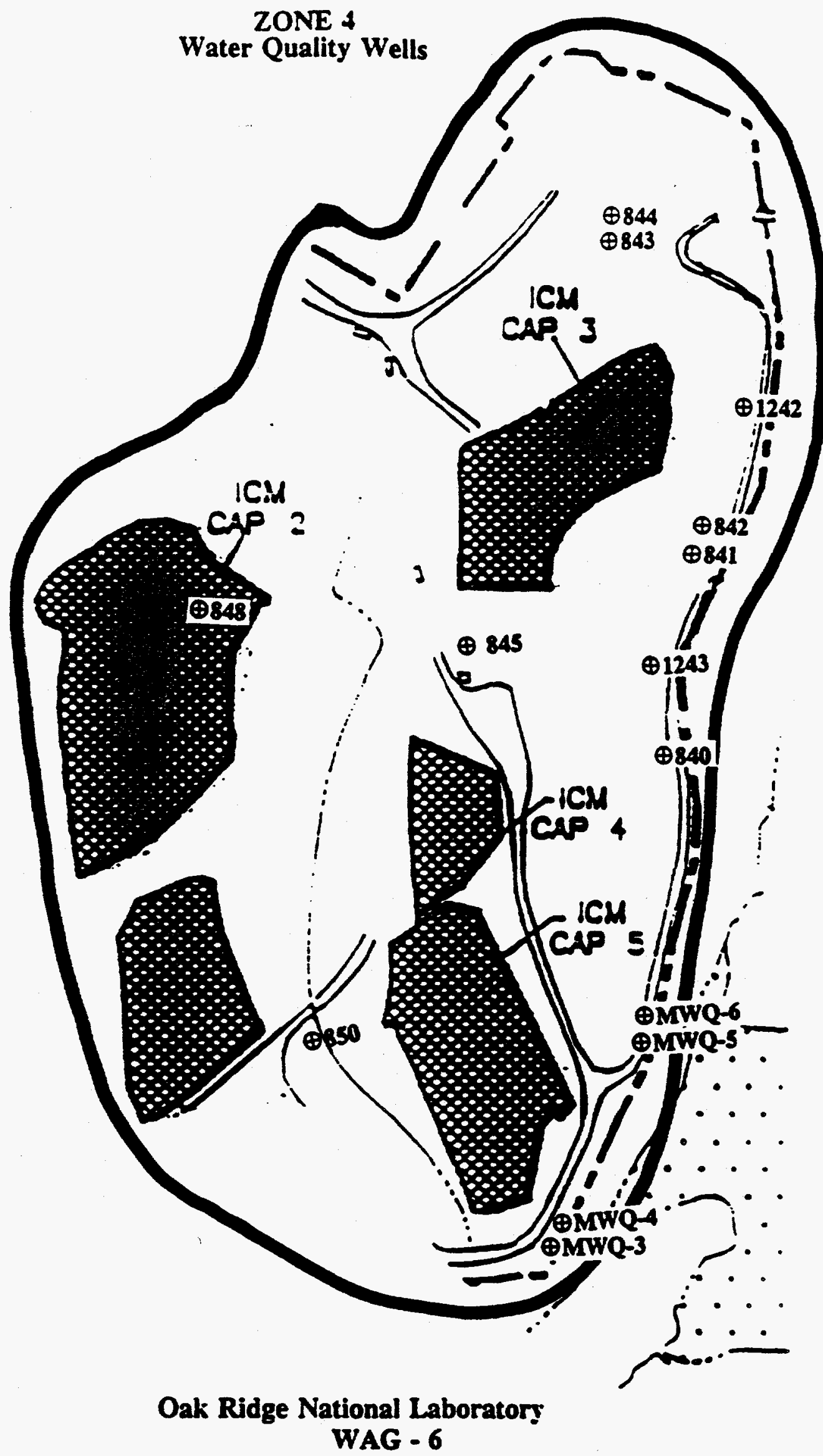


Zone 4 Contaminant list

\begin{tabular}{|c|c|c|c|c|c|c|}
\hline Contaninant & $\begin{array}{r}\text { TLV.T } \\
\text { or }\end{array}$ & $\begin{array}{l}\text { EL.TWA } \\
\text { TWA }\end{array}$ & $\begin{array}{r}\text { TLV. } \\
\text { rit. }\end{array}$ & $\begin{array}{l}\text { STEL/PFL-ST } \\
\text { TLV-C or } \\
\text { IDLH }\end{array}$ & Heuth effecta/target urgans & Chemlcul/physlcal properiles \\
\hline $\begin{array}{l}\text { Bis(2-ethylhexl)phothalate } \\
\text { Color: } \\
\qquad \begin{array}{l}\text { known carcinozen } \\
\text { Osuspect carcinozen }\end{array}\end{array}$ & $\begin{array}{l}\text { nV: } \\
\text { PEL: } \\
\text { REL: } \\
\text { DAC: }\end{array}$ & $\begin{array}{l}5 \mathrm{mg} / \mathrm{m}^{3} \\
5 \mathrm{mg} / \mathrm{m} 3 \\
5 \mathrm{mg} / \mathrm{m} 3\end{array}$ & $\begin{array}{l}\text { STEL: } \\
\text { IDLH: }\end{array}$ & $10 \mathrm{me} / \mathrm{m} 3$ & Mild initan to eyes and stin; affects GI treet & When heaved eniis acrid somske;insuluble \\
\hline $\begin{array}{l}\text { Methylene chloride } \\
\text { Color: Colorless } \\
\qquad \text { known carcinogen } \\
\text { Orupect cercinozen }\end{array}$ & $\begin{array}{l}\text { RV: } \\
\text { PEL: } \\
\text { REL: } \\
\text { DAC: }\end{array}$ & $\begin{array}{l}50 \mathrm{ppm} \\
500 \mathrm{ppm} \\
\mathrm{NE}\end{array}$ & $\begin{array}{l}\text { STEL: } \\
\text { IDIN: }\end{array}$ & $\begin{array}{c}\mathrm{NE} \\
3000 \mathrm{ppm}\end{array}$ & $\begin{array}{l}\text { Eyes, skin, liver, CVS, CNS irrilant. numboness. } \\
\text { tingling. vertigo. angina }\end{array}$ & $\begin{array}{l}\text { Liquid with choloform like inkw: } \\
\text { LEL:12\%:Sisl:296}\end{array}$ \\
\hline $\begin{array}{l}\text { Strontium.90 } \\
\text { Coler: } \\
\qquad \begin{array}{l}\text { Otwown carcinogen } \\
\text { O unpect carcinoten }\end{array}\end{array}$ & $\begin{array}{l}\text { RV: } \\
\text { PaL: } \\
\text { REL: } \\
\text { DAC: }\end{array}$ & & $\begin{array}{l}\text { STEL: } \\
\text { DLH: }\end{array}$ & $\mathrm{NE}$ & Skeletal system, respirstory system & Veriable \\
\hline $\begin{array}{l}\text { 1.1.1 Trichlorcethane } \\
\text { Color: Colorless } \\
\text { Otunown carcinogen } \\
\text { suspect carcinogen }\end{array}$ & $\begin{array}{l}\text { TLV: } \\
\text { PEL: } \\
\text { REL: } \\
\text { DAC: }\end{array}$ & $\begin{array}{c}350 \mathrm{ppm} \\
350 \mathrm{ppm} \\
\mathrm{Ne}\end{array}$ & $\begin{array}{l}\text { STEL: } \\
\text { BLH: }\end{array}$ & $\begin{array}{l}450 \mathrm{ppm} \\
1000 \mathrm{ppm}\end{array}$ & $\begin{array}{l}\text { CNS, CVS, eye, skin inituna, hendaches. } \\
\text { drowsinese, impaired judgement can be buorbed } \\
\text { Wrough stin to heart }\end{array}$ & $\begin{array}{l}\text { Liquid. mild chloruform like mlon:Sol:0.4\%: } \\
\text { LEL:7.5\% }\end{array}$ \\
\hline
\end{tabular}

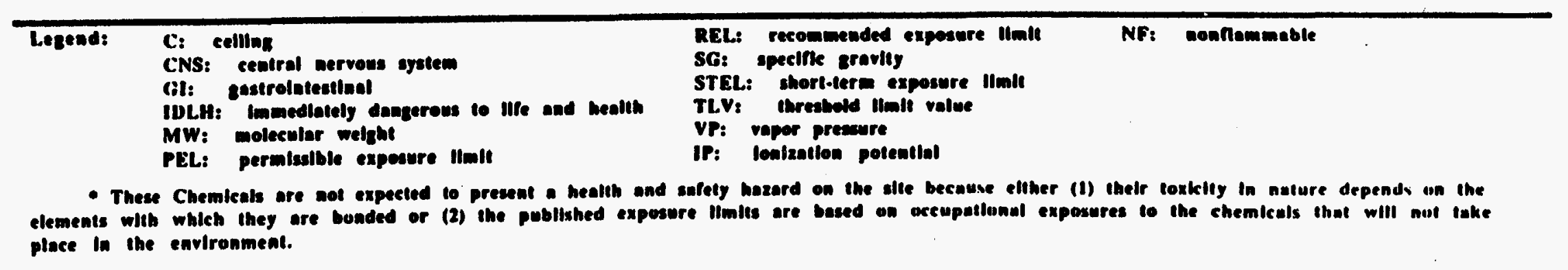


Zone 4 Contaminant List

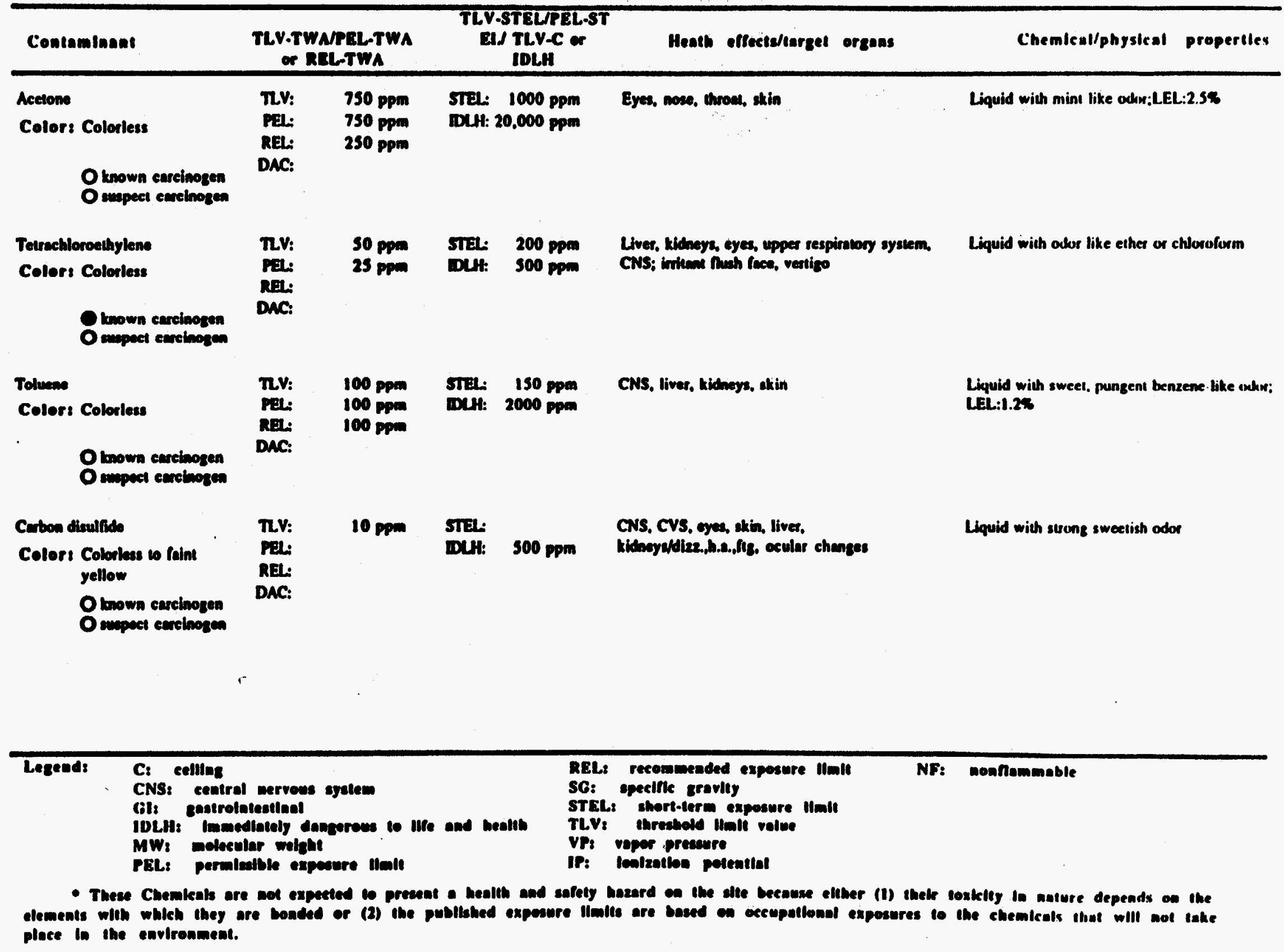


Zone 4 Contaminant List

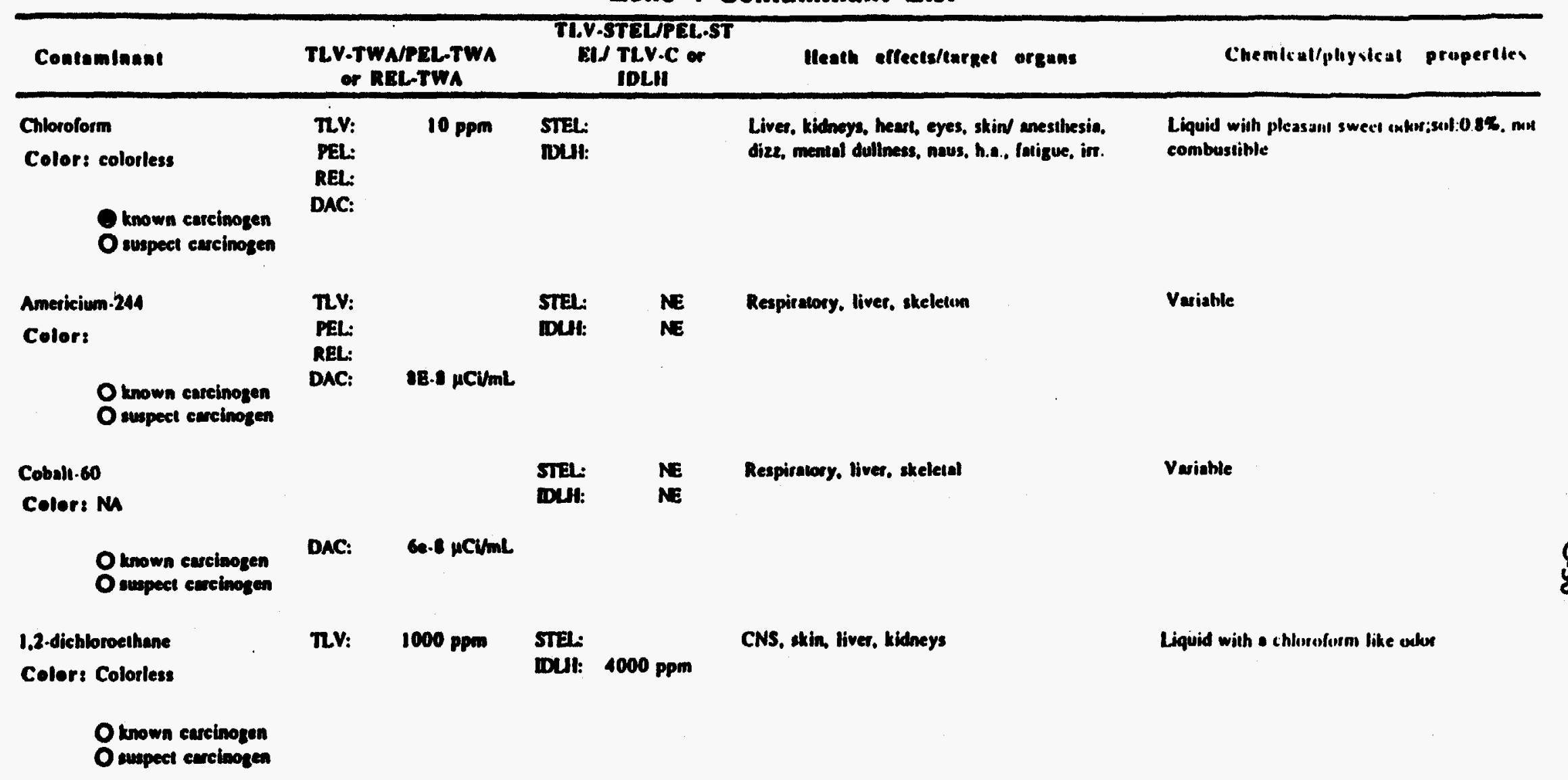

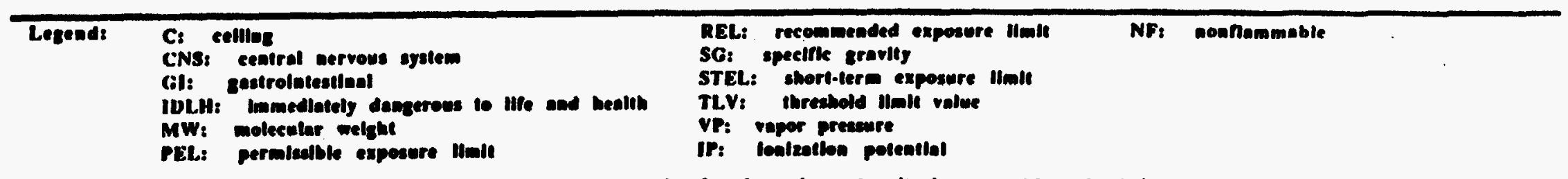

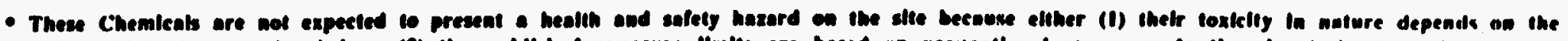

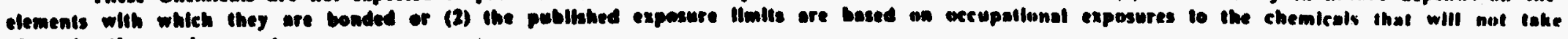
place in the envirengenent. 
Zone 4 Contaminant l.ist

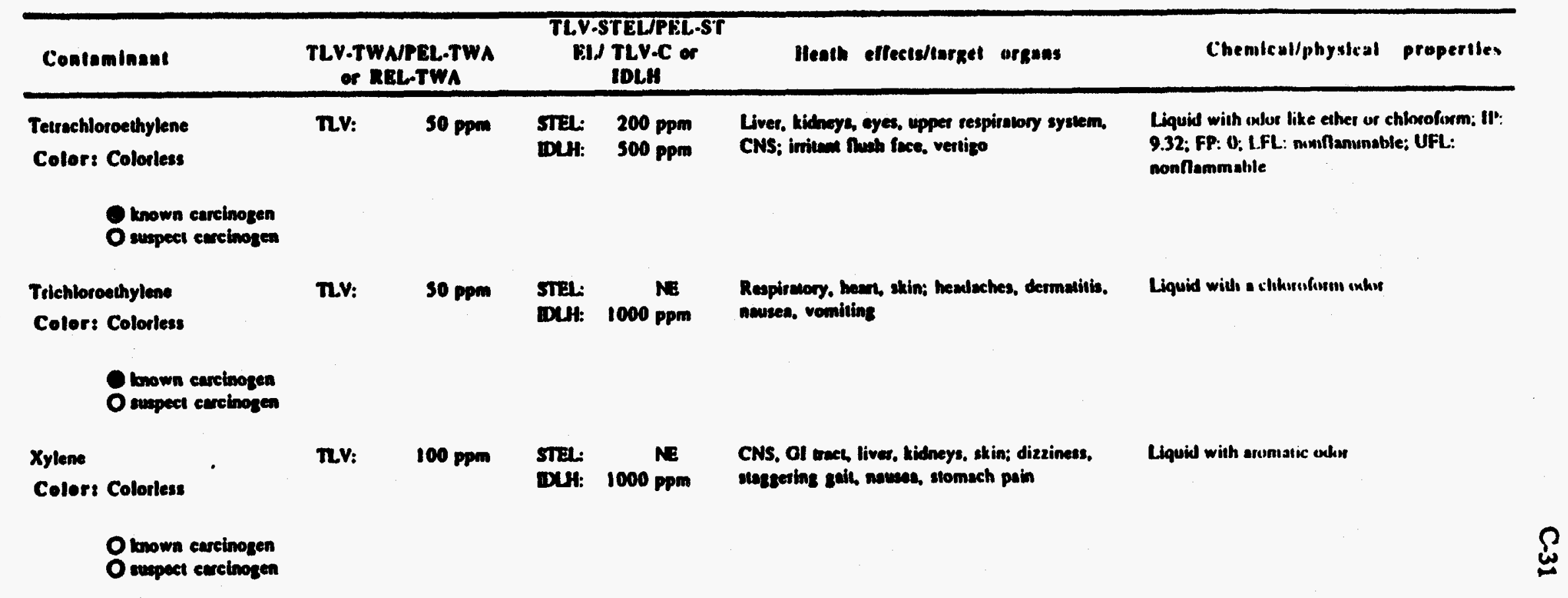

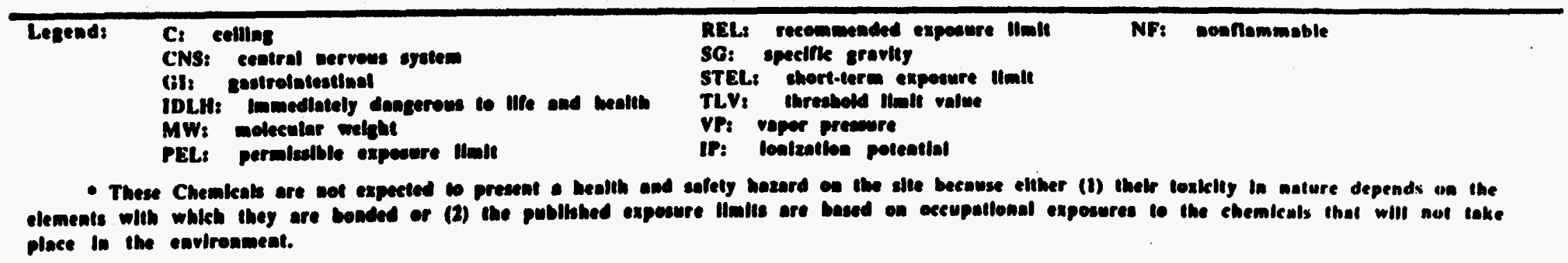




\section{C-32}

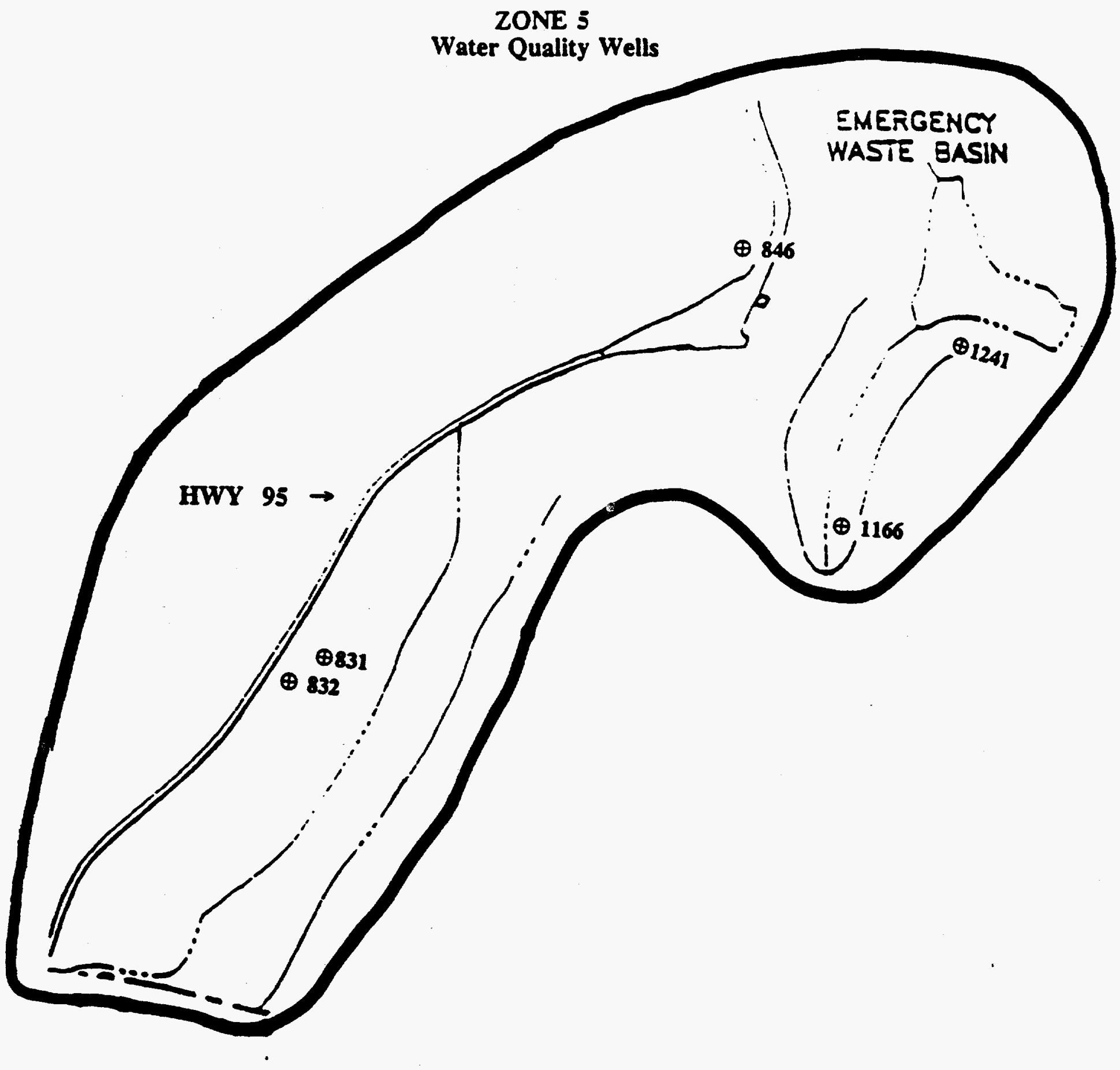

Oak Ridge National Laboratory

WAG - 6 
Zone 5 Contaminant List

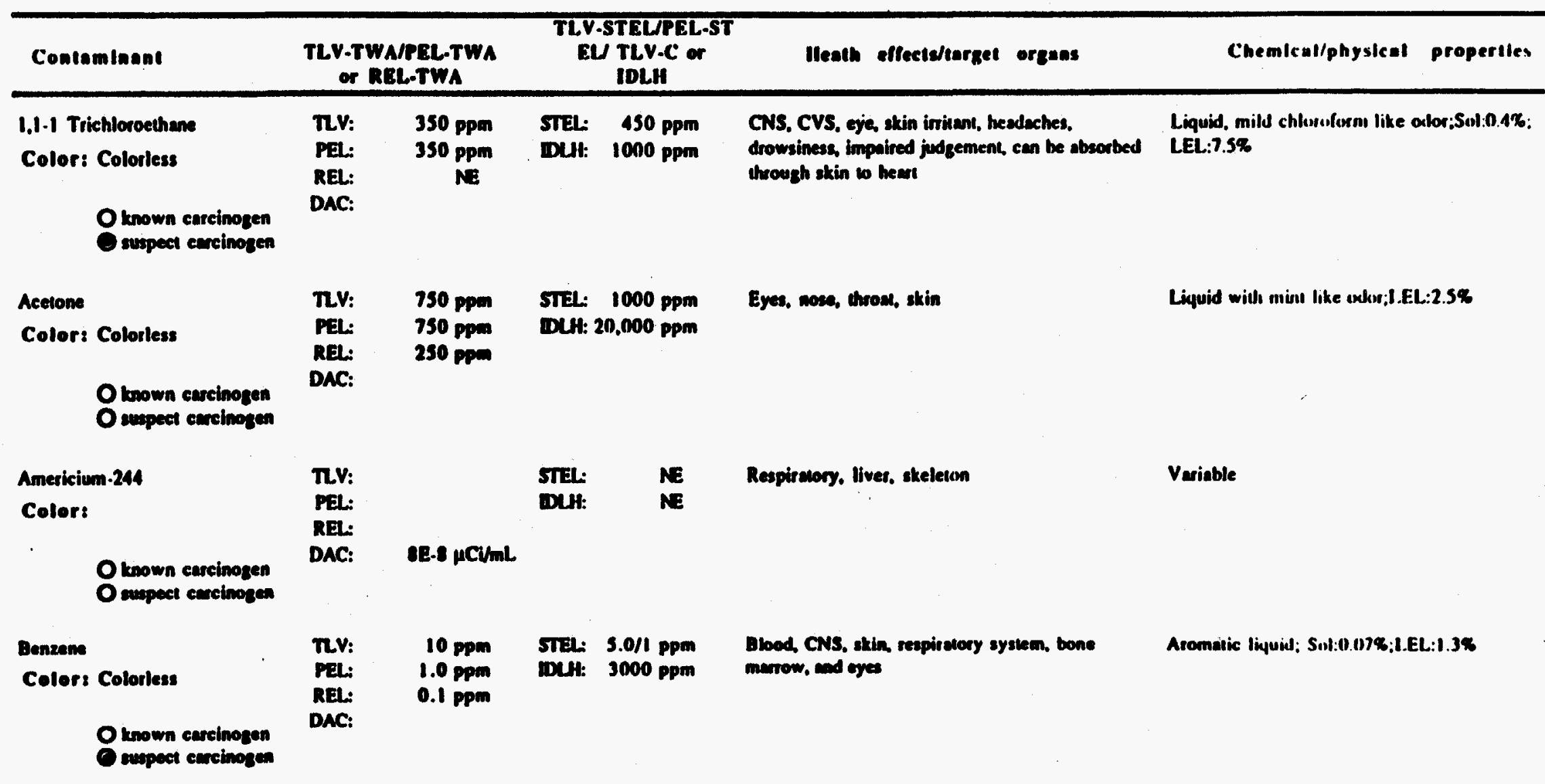

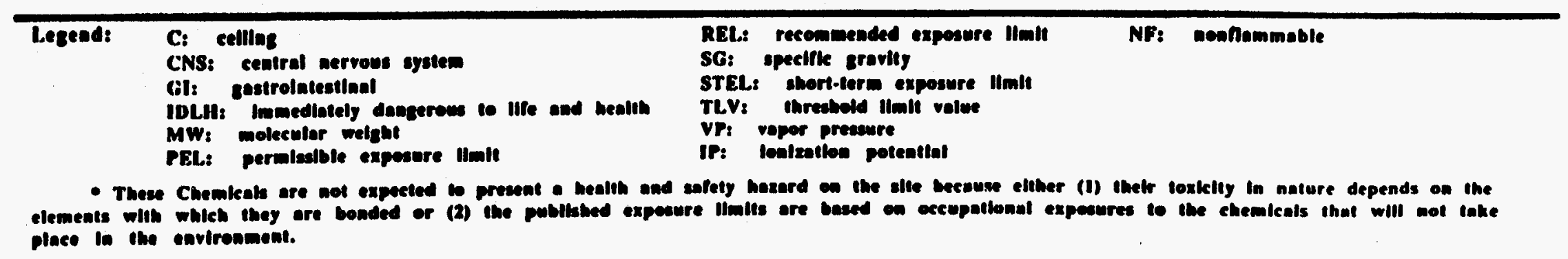


Zone 5 Contaminant List

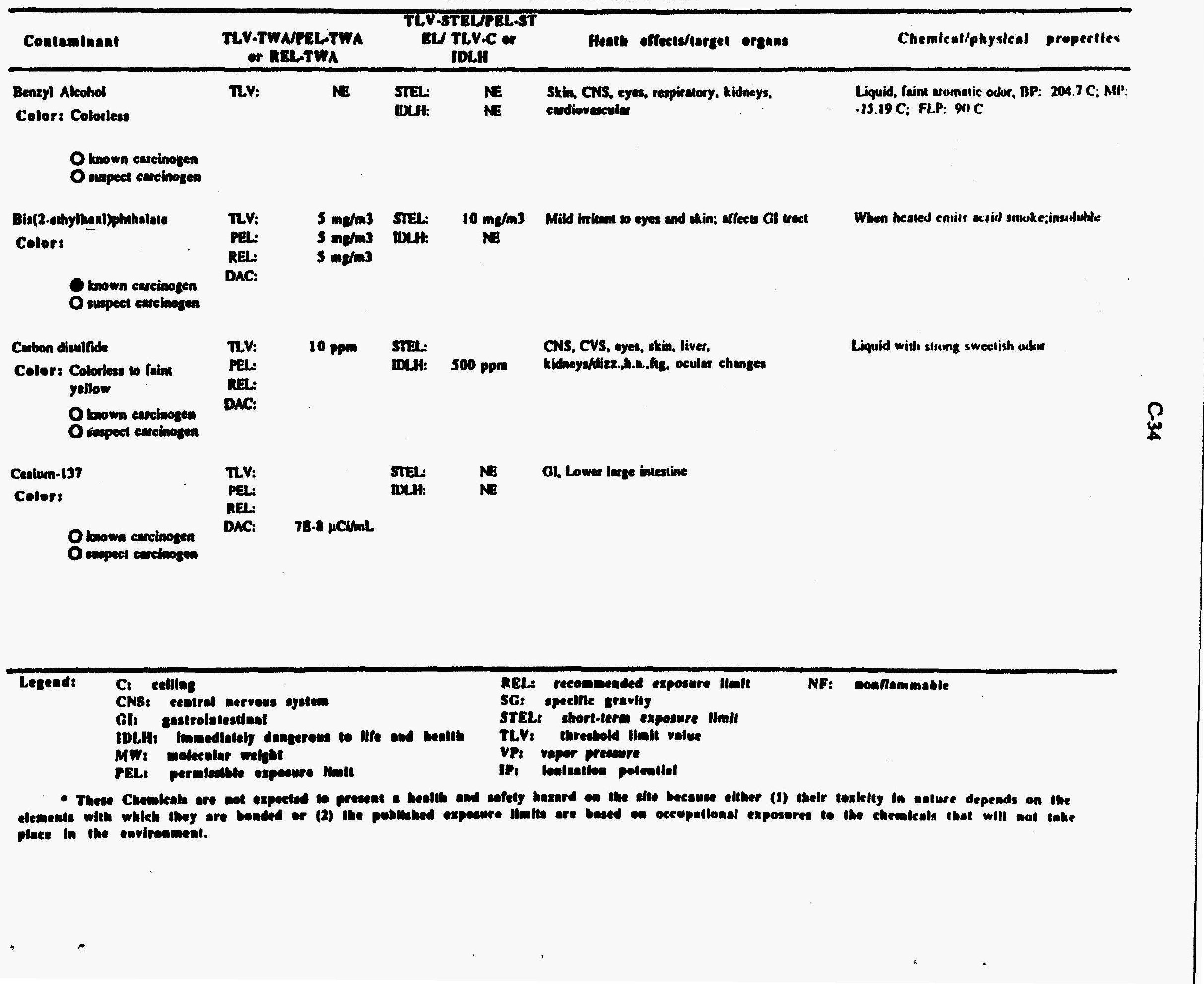


Zone 5 Contaminant List

\begin{tabular}{|c|c|c|c|c|c|c|}
\hline \multirow{2}{*}{$\begin{array}{l}\text { Centaminent } \\
\text { Chloroform } \\
\text { Culer: colorless }\end{array}$} & \multicolumn{2}{|c|}{$\begin{array}{l}\text { TLV-TWAMEL-TWA } \\
\text { or REL-TWA }\end{array}$} & \multicolumn{2}{|c|}{$\begin{array}{l}\text { TIV.STEL/PEL-ST } \\
\text { SIS TLV.C or } \\
\text { IDLII }\end{array}$} & \multirow{2}{*}{$\begin{array}{l}\text { Meath effects/turget organs } \\
\text { Liver, kidneys, hemr, eyes, sking anesthesia. } \\
\text { diz2, wental dullness, naus, ha., fatigue, irr. }\end{array}$} & \multirow{2}{*}{$\begin{array}{l}\text { Chemlcallphysical properiles } \\
\text { Liquid wilh pleasan sweel onlow:soll:0.84, un } \\
\text { combustible }\end{array}$} \\
\hline & $\begin{array}{l}\text { RLV: } \\
\text { PEL: } \\
\text { REL: } \\
\text { DAC: }\end{array}$ & $10 \mathrm{ppm}$ & $\begin{array}{l}\text { STEl: } \\
\text { DUIl: }\end{array}$ & & & \\
\hline $\begin{array}{l}\text { Cobalt.60 } \\
\text { Coter: NA }\end{array}$ & & & $\begin{array}{l}\text { STEL: } \\
\text { DULI: }\end{array}$ & $\begin{array}{l}N E \\
N E\end{array}$ & Respiratory, liver, skeleial & Vuriable \\
\hline $\begin{array}{l}\text { O known carcinogen } \\
\text { O suppect euclonogen }\end{array}$ & DAC: & Co.e nCUmb & & & & . \\
\hline $\begin{array}{l}\text { Isopropyl Alcohol } \\
\text { Coler: }\end{array}$ & $\mathbf{n v}:$ & $400 \mathrm{ppm}$ & $\begin{array}{l}\text { STEL: } \\
\text { WUH: }\end{array}$ & NE & Eyes, skin, respiravory & 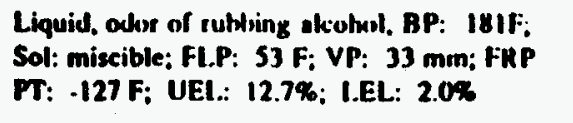 \\
\hline \multicolumn{7}{|l|}{$\begin{array}{l}\text { O bnown curcinosen } \\
\text { O suspect curcinogen }\end{array}$} \\
\hline $\begin{array}{l}\text { Methyleme chloside } \\
\text { Colort Colorless } \\
\text { Otnown cureinogen } \\
\text { owpect cereinoten }\end{array}$ & $\begin{array}{l}\text { RV: } \\
\text { PEL: } \\
\text { REL: } \\
\text { DAC: }\end{array}$ & $\begin{array}{l}50 \mathrm{ppm} \\
500 \mathrm{ppm} \\
\mathrm{NE}\end{array}$ & $\begin{array}{l}\text { STtal: } \\
\text { nuH: }\end{array}$ & $\begin{array}{c}\mathrm{NE} \\
3000 \mathrm{ppm}\end{array}$ & $\begin{array}{l}\text { Eyes, skin, liver, CVS, CNS irritant, numbness. } \\
\text { tingling, ventige, engins }\end{array}$ & $\begin{array}{l}\text { Liquid with clowhform like adhr: } \\
\text { LEL:12\%;Sul:2\% }\end{array}$ \\
\hline
\end{tabular}

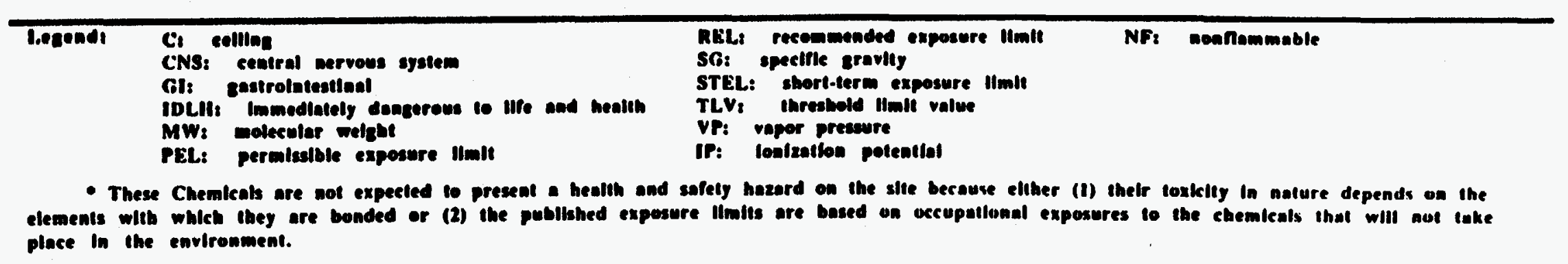


Zone 5 Contaminant List

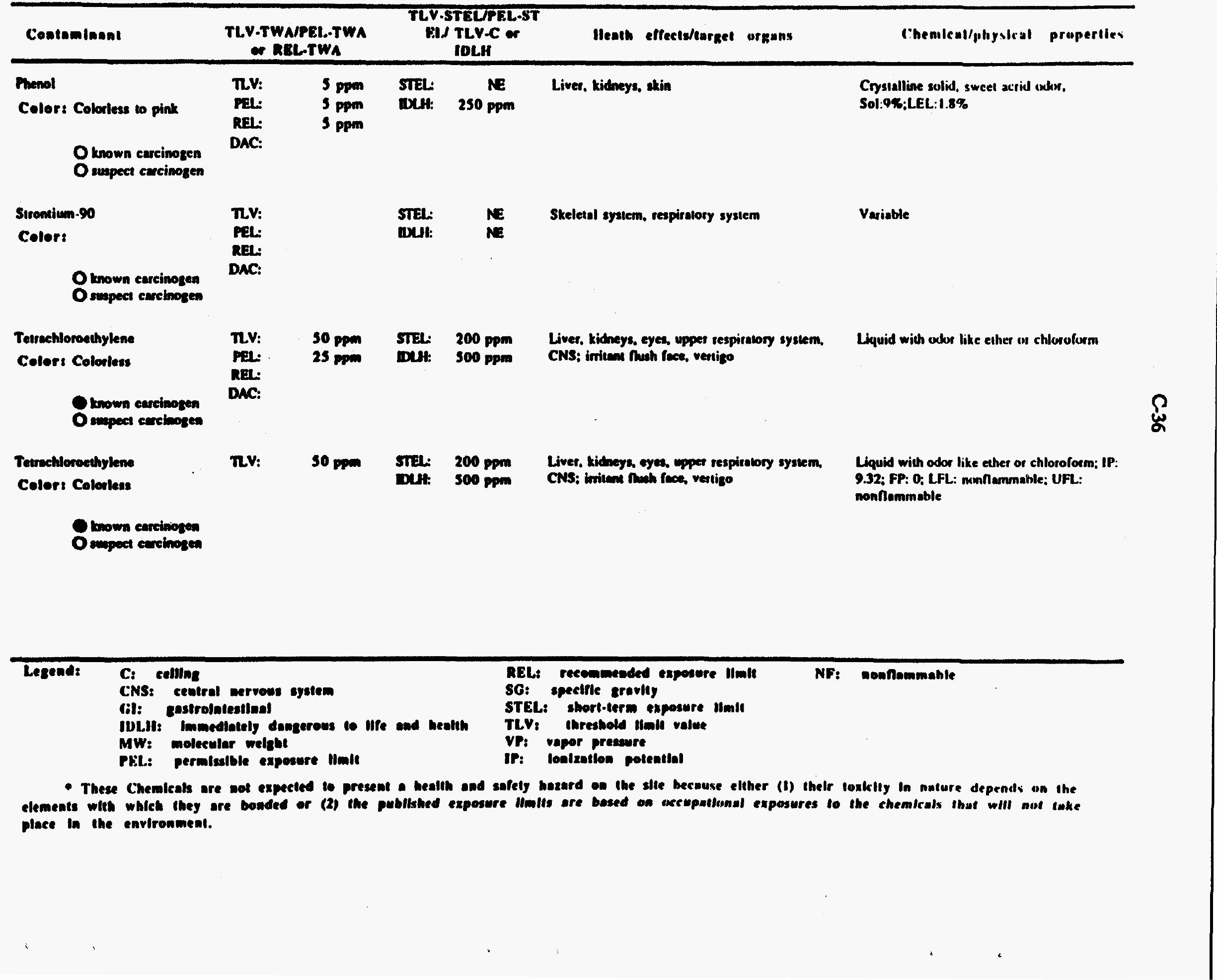




\section{Zone 5 Contaminant List}

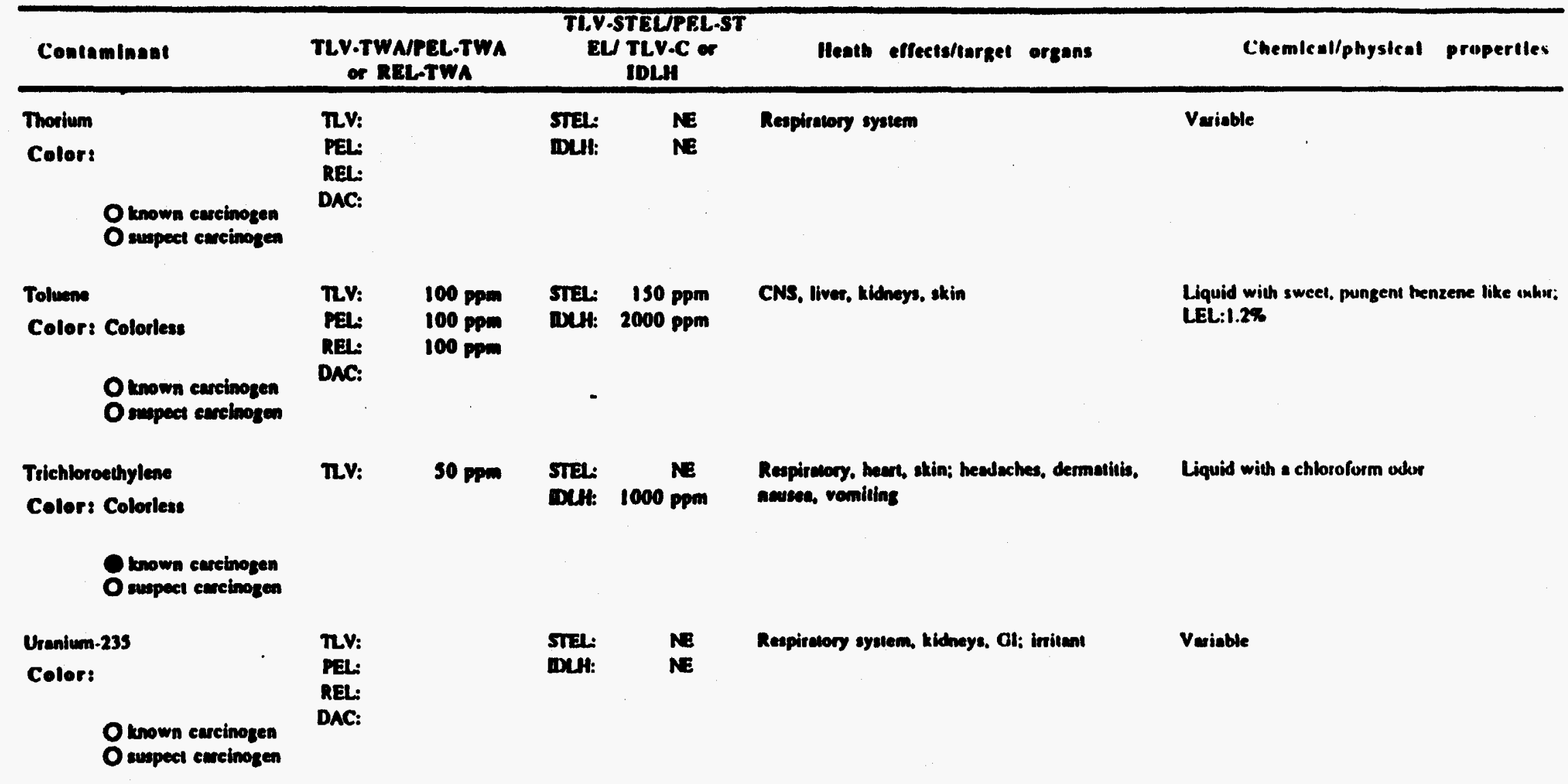

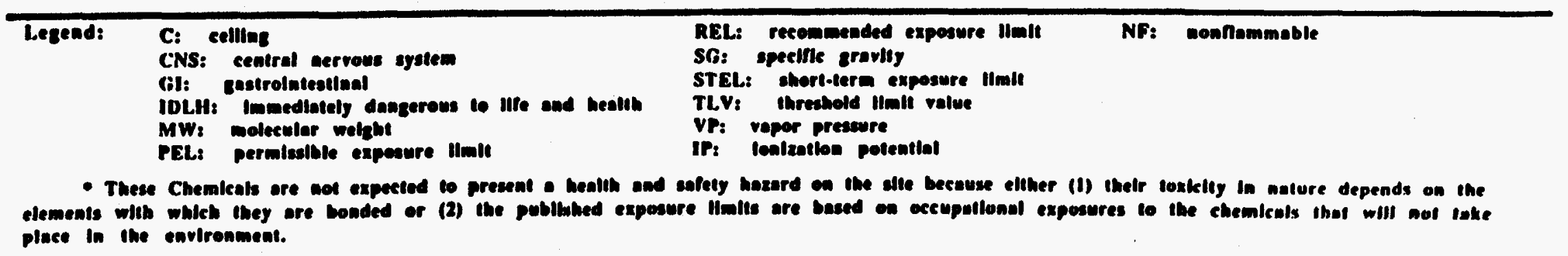


Zone 5 Contaminant I.ist

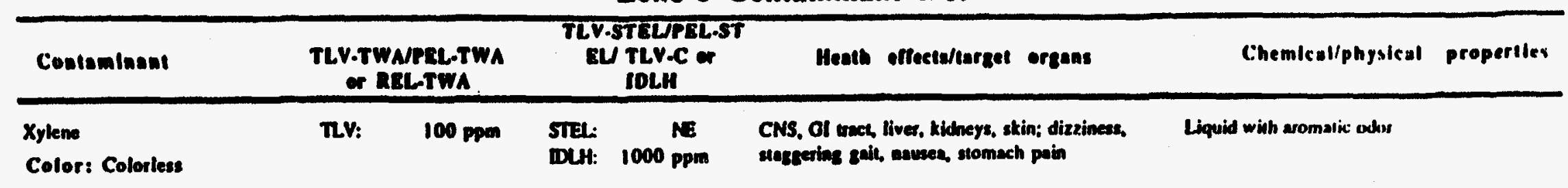

O trown carcinogen

Orempect curcinogen 


\section{TASK BREAKDOWN}

\subsection{TASK DESCRIPTION}

Task: Groundwater quality sampling and analysis

Type of Work: ( ) Intrusive (X) Nonintrusive

Engineering Controls:

Administrative Controls (required permits, training, etc.): Administrative controls for training requirements can be found in the WAG 6 Training Program (X-OE-703, Rev. 0 ) and the WAG 6 HASP.

\subsection{INITIAL LEVEL OF PERSONAL PROTECTIVE EQUIPMENT}

Level of Protection: $\quad \begin{array}{llllll}\text { ( ) A } & \text { ( ) B } & \text { ( ) C } & \text { (X) D } & \text { (X) Modified }\end{array}$

Respirator: ( ) SCBA ( ) Full-face ( ) Half-face respirator

( ) PAPR ( ) Other

Cartridge:

Protective Clothing: ( ) Encapsulating suit

( ) Saranex

(X) Tyvek (if upgraded by the SSHO;

( ) C-zone see action sevels in Sect. 5)

( ) Other

( ) Splash suit

(X) Company clothing (khakis)

Head/eye/ear: ( ) Hard hat

(X) Safety glasses

( ) Goggles

(X) Splash shield

( ) Ear plugs

( ) Ear muffs

( ) Other

Gloves: ( ) Nitrile

(X) Latex

( ) Neoprene

( ) PVC

( ) Other

( ) Vinyl

( ) Leather

Footwear: (X) Steel-toed leather ( ) Chemical overboots

( ) Steel-toed rubber ( ) Other

Note: Company-issued shoes/boots are required for PPE dress-out if potential radiological contamination exists.

Describe the donning/doffing steps: Donning and doffing steps for PPE are provided here and in the WAG 6 HASP. 


\section{DONNING LEVEL D (Modified)}

1. Don inner plastic boots.

2. Don cotton liners.

3. Don rubber gloves.

4. Don outer rubber boots.

5. Tape over outside pants cuffs.

\section{DOFFING LEVEL D (Modified)}

1. Remove outer tape.

2. Remove outer rubber boots (upon exiting the controlled access zone).

3. Remove rubber gloves.

4. Remove plastic boots (upon exiting the controlled access zone).

5. Remove cotton liners.

6. Perform whole-body frisk.

\section{DONNING LEVEL C}

1. Tear and tab tape ( 5 pieces for wrists, ankles, and front seam of Tyvek).

2. Don Energy Systems- or contractor-furnished clothing and Tyvek; button to the neck.

3. Check for proper badging and dosimetry.

4. Tape front seam; place tab at the top for each access.

5. Check shoe covers (black rubber boots) for holes and tears.

6. Don shoe covers.

7. Tuck contractor-furnished clothing or Tyvek into shoe covers (black rubber boots) and tape seams.

8. Don coveralls and tape front seams (if applicable).

9. Tape coveralls to the outside (over) shoe covers (black rubber boots).

10. Don cotton glove liners and tuck under sleeves.

11. Check rubber outer gloves (magenta/red) for leaks.

12. Don rubber gloves and tape seams over Tyvek sleeves.

\section{DOFFING LEVEL C}

1. Remove exposed tape

a. from rubber gloves,

b. from front seam of coveralls,

c. from shoe covers (black rubber boots).

2. Remove rubber gloves (pull inside out).

3. Remove Tyvek, inside outward, touching inside only.

4. Remove tape from shoe covers (black rubber boots) and contractor-furnished clothing.

5. Remove shoe cover (black rubber boot) and place each foot across the step-off pad one at a time.

6. Perform personnel frisking before exiting the controlled access zone. 
Modifications allowed: All upgrades of PPE must be approved by the SSHO and by the appropriate safety and health representative. Downgrades in PPE will be justified and documented in the site logbook by the SSHO.

Additional PPE information may be found in Sect. 5 of the WAG 6 HASP. 


\section{MONITORING REQUIREMENTS}

A baseline exposure rate for the work site will be measured by Site HP before commencement of work activities. Site exposure rates will be updated on a 6-month cycle.

\subsection{DIRECT READING INSTRUMENTS}

\begin{tabular}{|c|c|c|c|c|}
\hline & Task(s) & $\begin{array}{l}\text { Monitoring } \\
\text { Frequency }\end{array}$ & $\begin{array}{l}\text { Action } \\
\text { Levels } \\
\end{array}$ & $\begin{array}{c}\text { Action } \\
\text { Guidelines } \\
\end{array}$ \\
\hline LEL meter & NA & & $10 \% \mathrm{LEL}$ & \\
\hline $\mathrm{O}_{2}$ meter & NA & & $>22 \% \mathrm{O}_{2}$ & \\
\hline Colorimetric indicator tubes & NA & & $1 / 2 \mathrm{PEL}$ & \\
\hline Photoionization detector (PID) & IH & Initial well cap remov & $5 \mathrm{ppm}^{*}$ & Halt work; contact IH \\
\hline Flame ionization detector (FID) & NA & & 5 ppm & \\
\hline Alpha meter & HP & Before exiting & See HASP Table 3 & Contact HP \\
\hline Beta/gamma meter & HP/worker & Upon exiting & See HASP Table 3 & Contact HP \\
\hline Area radiation monitors & NA & & & \\
\hline Noise meter & NA & & $85 \mathrm{dBA}$ & \\
\hline Other (Specify) & $\mathbf{N A}$ & & & \\
\hline
\end{tabular}

*Action levels are ppm above background per $5 \mathrm{~min}$. All personnel are to frisk themselves and sampling equipment before exiting each sampling area.

\subsection{PERSONAL MONITORING}

\begin{tabular}{|c|c|c|c|}
\hline & Task(s) & $\begin{array}{c}\text { Monitoring } \\
\text { Frequency }\end{array}$ & $\begin{array}{c}\text { Action } \\
\text { Guidelines }\end{array}$ \\
\hline Whole-body dosimetry & GWQ & Continuous & Contact HP \\
\hline Extremity dosimetry & NA & & \\
\hline Whole-body count & GWQ & Yearly & Contact HP \\
\hline Urinalysis/bioassay & GWO & 6 months & Contact HP \\
\hline Chemical air sampling & NA & & \\
\hline Radiation air sampling & NA & & \\
\hline Personal sampling pumps & NA & & \\
\hline
\end{tabular}

In addition to standard site monitoring procedures, Energy Systems employees will be monitored by ORNL IH representatives. Instruments used by IH representative will be calibrated and maintained in accordance with IH Standard Operating Procedures. Instruments used by the Office of Radiation Protection are calibrated and source-checked in accordance with established Health Physics procedures. Instruments used by MAD representatives will be calibrated and maintained in accordance with MAD procedures.

Site monitoring requirements may change based on site conditions. All changes must be documented in the site logbook. 


\section{SITE CONTROL}

Site work zones are required to reduce the accidental spread of hazardous substances from contaminated areas to clean areas. Therefore, a controlled access zone will be established at the site. The identification of the zone will provide for control of operations and flow of personnel. The HPC will provide signs to be posted at the site for HAZWOPER requirements. The HP will determine radiological postings. Should additional barriers (e.g., rope, tape) or signs be required, HP, IH, and IS will be consulted. The HPC may modify the zones for short-term, transient-type projects. The modification would include use of the HAZWOPER barrier tape or A-frame sign, if material is in stock. Additional information regarding site control may be found in Sect. 7 of the ORNL HAZWOPER Program Manual.

Personnel accessing the zone must meet access requirements as stated in the WAG 6 HASP and this plan, and at the entrance of the zone. Entrance and exit points for the zone will be clearly marked. Perimeter monitoring of the zone will be conducted periodically to ensure correct placement of the zone. The SSHO is responsible for ensuring that all workers and visitors meet site access requirements. Section 9 is a record of site access requirements and personnel qualifications.

A site map is provided at the end of this section that includes the location of the emergency assembly area and the emergency evacuation routes. 
Map Page insert here 


\section{DECONTAMINATION}

The purpose of decontamination is to prevent contaminants that may be present on protective clothing and equipment from coming into contact with personnel as they doff PPE. Also, decontamination protects workers from hazardous substances that may contaminate and eventually permeate the PPE used on site; it protects personnel by minimizing the transfer of harmful materials into clean areas. Combining decontamination with the correct sequential method of removing PPE will prevent exposure to personnel leaving the work areas as well as offsite migration of contaminants. Generally, decontamination is accomplished by starting with the most heavily contaminated item and progressing to the least contaminated item.

Personnel will remove any disposable PPE and dispose of it in provided containers before leaving the controlled access zone. The steps for doffing and disposal of PPE can be found in Sect. 5 of the WAG 6 HASP.

Materials needed for decontamination for this project include (1) an industrial sprayer and (2) deionized water.

Equipment decontamination procedures can be found in Sect. 2 of the Groundwater Quality Sampling and Analysis Plan. 


\section{EMERGENCY PREPAREDNESS}

The responsibility for day-to-day implementation of this information lies primarily with the SSHO. During an actual emergency response situation, the SSHO will serve as the Emergency Coordinator until the Laboratory Shift Superintendent (LSS) or emergency response team arrives.

Medical assistance will be provided by the Health Division, which is located at Building $4500 \mathrm{~N}$. In the event of an emergency, dial 911 to reach ORNL Emergency Response. The LSS will provide emergency response personnel and will coordinate emergency assistance. The radio number for the LSS is Station 295. The telephone number for the LSS is 574-6606. The nearest telephone and fire alarm box is located at the tumulus site. In the event that the LSS is not available, emergency services may be reached at the telephone numbers shown below.

The SSHO will perform the following pre-emergency tasks before starting field activities and will coordinate emergency response with the LSS.

1. Locate nearest telephone and alarm station.

2. Confirm and post emergency telephone numbers.

3. Post site map of work areas marked with evacuation routes.

4. Inventory and check out on-site emergency equipment and supplies, as warranted.

In the event of an emergency, a fire extinguisher, medical kit, and emergency eye wash kit are located in the CDM Federal vehicles and in the clean zone. In addition, spill control kits may be found in the permanent decontamination area located outside the clean zone.

In the event of an emergency that requires evacuation of the site, verbal instruction will be given by the SSHO to evacuate the area. Personnel will exit to a predesignated support area. At this point, the SSHO will account for all personnel, ascertain information about the emergency, and give further instructions to the on-site personnel. In all situations that require evacuation, personnel shall not reenter the work area until the conditions causing the emergency have been corrected; the hazard reassessed; the Work Plan and HASP revised, approved, and reviewed with on-site personnel; and instructions given for reentry.

\begin{tabular}{lll} 
Emergency Personnel & Phone & Radio \# \\
\hline ORNL Emergency Response & $\mathbf{9 1 1}$ & 295 \\
Laboratory Shift Superintendent & $\mathbf{5 7 4 - 6 6 0 6}$ & \\
Fire Department & $574-5678$ & \\
Medical Center & $574-7431$ & \\
Security & $574-7199$ & \\
Industrial Hygiene & $576-5064$ \\
Industrial Safety & $574-6679$ \\
Radiation Protection & $599-1338$ & \\
Environmental Compliance & $574-7294$ \\
Emergency Communication Center & $574-6646$ \\
Facility Manager (K. Wilson) & $576-5290$ \\
Project Manager (D. McCurry) & $421-4724$ \\
ORNL ER and Environmental Health & & \\
$\quad$ and Safety Manager (C. Clark) & $574-8268$ \\
Project Engineer (R. Williams) & $241-4722$
\end{tabular}

The SSHO will brief workers on emergency response procedures and the evacuation rome in the pre-entry briefing. 


\section{TRAINING/MEDICAL SURVEILLANCE REQUIREMENTS}

List applicable training/medical requirements for this project. All site personnel and visitors requiring access to the work zones (contamination reduction zone and exclusion zone) will be required to meet these access requirements.

\subsection{PROJECT TRAINING/MEDICAL SURVEILLANCE REQUIREMENTS}

Training

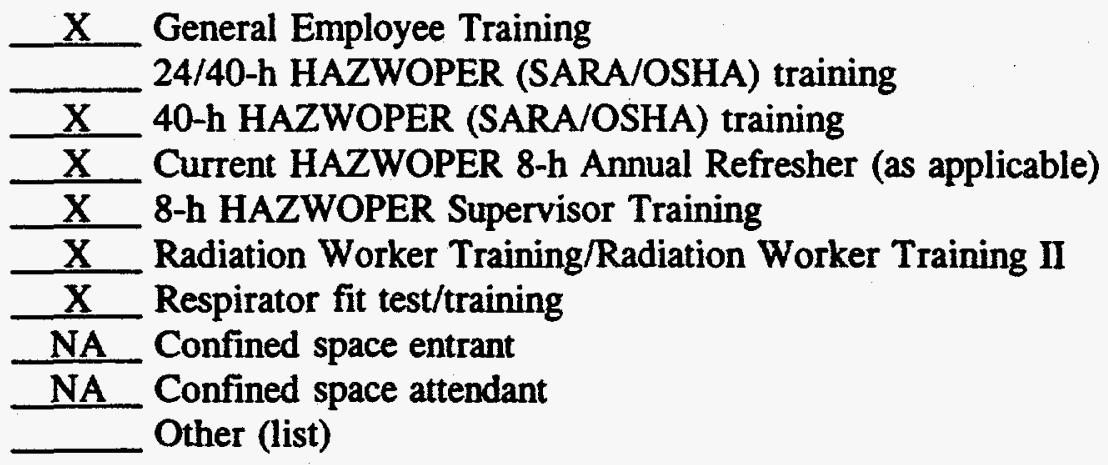

Twenty-four-hour HAZWOPER training is applicable for individuals not requiring the use of respiratory training.

\section{Medical Surveillance}

The ORNL Hazardous Waste Worker Medical Surveillance Program is applicable for individuals meeting criteria as specified in Sect. 9 of the ORNL HAZWOPER Program Manual. Subcontracted personnel are enrolled in a medical surveillance program comparable with the ORNL Medical Surveillance Program.

Note: If site conditions change, or if other hazards are detected, the training and access requirements will be revised accordingly.

\subsection{SITE PERSONNEL QUALIFICATIONS}

1. Name: J. B. Watson Assigned tasks: Obtaining groundwater samples

Badge number: 9971

$\begin{array}{llll} & \text { YES } & \text { NO } & \frac{\text { DATE }}{9 / 93} \\ \text { General Employee Training: } & \text { (X) } & \text { ( ) } & \frac{7 / 93}{7 / 93} \\ \text { 24-h training: } & \text { (X) } & \text { ( ) } & \frac{7 / 93}{\text { NA }} \\ \text { 40-h training: } & \text { (X) } & \text { ( ) } & \frac{\text { ( ) }}{3 / 92} \\ \text { Annual Refresher Training: } & \text { (X) } & \text { ( ) } & \end{array}$




\begin{tabular}{|c|c|c|c|}
\hline & YES & $\underline{\text { NO }}$ & $\underline{\text { DATE }}$ \\
\hline Radiation Worker Training II: & () & () & NA \\
\hline Respirator fit tested/trained: & $(\mathrm{X})$ & () & $8 / 93$ \\
\hline Confined Space Entry Training: & () & () & NA \\
\hline Medical Surveillance Program: & $(\mathrm{X})$ & () & $9 / 93$ \\
\hline Whole Body Count (in vitro): & $(X)$ & () & $2 / 94$ \\
\hline Bioassay (in vitro): & $(\mathrm{X})$ & () & $2 / 94$ \\
\hline Specialized Equipment Training: & () & () & NA \\
\hline First Aid/CPR: & $(j)$ & ( ) & NA \\
\hline
\end{tabular}

Other training:

2. Name: B. T. Hendrix

Assigned tasks: Obtaining groundwater samples

Badge number: 9959

\begin{tabular}{|c|c|c|c|}
\hline & YES & NO & DATE \\
\hline General Employee Training: & $(\mathrm{X})$ & $\overline{()}$ & $10 / 93$ \\
\hline 24-h training: & $(\mathrm{X})$ & ( ) & $7 / 93$ \\
\hline 40-h training: & $(\mathrm{X})$ & ( ) & $7 / 93$ \\
\hline Annual Refresher Training: & $(\mathrm{X})$ & ( ) & $7 / 93$ \\
\hline Supervisor Training: & ( ) & ( ) & NA \\
\hline Radiation Worker Training: & $(\mathrm{X})$ & ( ) & $3 / 92$ \\
\hline Radiation Worker Training II: & () & ( ) & NA \\
\hline Respirator fit tested/trained: & $(\mathrm{X})$ & ( ) & $8 / 93$ \\
\hline Confined Space Entry Training: & () & ( ) & NA \\
\hline Medical Surveillance Program: & $(X)$ & ( ) & $9 / 93$ \\
\hline Whole Body Count (in vitro): & $(\mathrm{X})$ & ( ) & $2 / 94$ \\
\hline Bioassay (in vitro): & $(X)$ & ( ) & $2 / 94$ \\
\hline Specialized Equipment Training: & () & ( ) & NA \\
\hline First Aid/CPR: & () & ( ) & NA \\
\hline
\end{tabular}

3. Name: David Fugate

Assigned tasks: Groundwater quality sample task leader

\begin{tabular}{|c|c|c|c|}
\hline General Employee Training: & $\frac{Y E S}{(X)}$ & $\frac{\text { NO }}{()}$ & $\frac{\text { DATE }}{10 / 93}$ \\
\hline 24-h training: & () & ( ) & NA \\
\hline 40-h training: & $(X)$ & ( ) & $8 / 93$ \\
\hline Annual Refresher Training: & () & ( ) & NA \\
\hline Supervisor Training: & $(\mathrm{X})$ & () & $10 / 93$ \\
\hline Radiation Worker Training: & () & ( ) & NA \\
\hline Radiation Worker Training II: & $(X)$ & ( ) & $9 / 93$ \\
\hline Respirator fit tested/trained: & $(X)$ & ( ) & $8 / 93$ \\
\hline Confined Space Entry Training: & () & ( ) & NA \\
\hline Medical Surveillance Program: & $(\mathrm{X})$ & ( ) & $8 / 93$ \\
\hline Whole Body Count (in vitro): & () & ( ) & \\
\hline Bioassay (in vitro): & () & ( ) & \\
\hline Specialized Equipment Training: & ( ) & ( ) & \\
\hline
\end{tabular}




\section{C-49}

First Aid/CPR:

$\underline{\mathrm{YES}}$

$\underline{\mathrm{NO}}$

DATE

(X)

10/93

Other training: Waste Generator Training for 90-Day Accumulation, Hazardous Waste Characterization, RCRA Cap Access Training, Satellite Waste Accumulation Training, Lowlevel Waste Training. 


\section{DISTRIBUTION}

1. J. Bohannon

2. T. Bonine

3. H. L. Boston

4. W. D. Brickeen

5. C. Callis (CDM Federal Programs Corporation)

6. R. Clapp

7. N. Dailey

8. S. B. Garland

9. D. Garrett

10. J. Guilford

11. P. J. Halsey

12. B. L. Kimmel

13. A. J. Kuhaida

14. C. Manrod

15. G. Moline

16. B. McClelland

17. P. T. Owen ( 2 copies)

18. S. Pack (Science Applications International Corporation)

19. H. Quarles

20. W. Schram

21. P. A. Schrandt

22. K. Wilson

23. P. S. Wood

24. ORNL Patent Section

25. Central Research Library

26. ER Document Management Center - RC ( 3 copies)

27. ORNL ER Document Management Center ( 3 copies)

28. ORNL Laboratory Records

29. Office of Assistant Manager for Energy Research and Development, DOE Oak Ridge Operations Office, P. O. Box 2001, Oak Ridge, Tennessee 37831-8600

30. Office of Scientific and Technical Information, P. O. Box 62, Oak Ridge, Tennessee 37831 (2 copies)

31. File - Administrative Record 


\section{DISCLAMMER}

Portions of this document may be illegible in electronic image products. Images are produced from the best available original document. 